\title{
1973-1998: Twenty-Five Years of Activity of The Geneva Association
}

\section{TABLE OF CONTENTS}

1. 1973: THE DAWNING OF A NEW ERA FOR THE INSURANCE INDUSTRY AND THE WORLD ECONOMY

1.1. Managing Vulnerability: A Key Economic Issue

1.2. The New Image of Insurance: Becoming a Key Strategic Issue in the Contemporary Economy

1.3. From "Limits to Growth" to "Limits of State Intervention"

2. THE RESEARCH PROGRAM ON SOCIAL SECURITY, SAVINGS, LIFE INSURANCE, THE FOUR PILLARS AND ON HEALTH ECONOMICS

3. INDUSTRIAL DEVELOPMENT, TECHNOLOGY, RISK MANAGEMENT AND INSURANCE

4. STRATEGIC ISSUES AND INTERNATIONAL ECONOMIC ASPECTS OF INSURANCE

4.1 The General Assemblies and The Geneva Lectures

4.2. WIN - The World Insurance Program

4.2.1. The Liberalization of Trade in Services

5. DEVELOPING INSURANCE ECONOMICS

5.1. The Economic Function of Insurance

5.2. The University Program on Risk, Insurance and the Economics of Uncertainty

5.3. Insurance in the "Service Economy"

6. OTHER STUDIES IN RISK AND INSURANCE ECONOMICS

7. METHODS OF WORK AND ORGANIZATION

8. THE GENEVA ASSOCIATION PUBLICATIONS

9. FROM THE SCRAPBOOK OF THE GENEVA ASSOCIATION 


\section{1973: The Dawning of a New Era for the Insurance Industry and the World Economy}

\subsection{Managing vulnerability: a key economic issue}

It is important to remember that the Geneva Association was founded in 1973. Twenty five years later the intuition of the founding fathers of the "International Association for the Study of Insurance Economics" appears to have been particularly farsighted.

In 1973 a number of illusions started to crumble. One such illusion was the idea that the modern world would bring greater simplicity and efficiency to economic management in the advanced industrial countries, less uncertainty at all levels and a lasting guarantee of growing economic welfare and full employment for everyone.

Just a few years prior to 1973, alarm signals began to sound warning that the current long period of very high economic growth in the industrialized countries could not last forever. Towards, the end of the sixties objective indications of a trend towards increasing uncertainty was observed in many sectors of industry and research. And it was intuition of this emerging trend which largely inspired the discussions which led to the founding of the Geneva Association.

More specifically, 1973 was the year when the period of extraordinary overall economic growth that had started right after World War Two (at an average rate for all industrialized countries of $6 \%$ p. a.) came to a definitive halt. The oil crisis was the first dramatic signal of a period of profound economic change and adjustment. Since then, economic development has slowed down to an average rate of $2-3 \%$. Economists have learned since to view a $3 \%$ growth as a good one, and they consider a soaring economy in an industrialized country when growth is at $3.5 \%$. It is interesting to note that a growth of $2-3 \%$ had in fact been the rate of development overall for the two preceding centuries during the period of the Industrial Revolution. The reasons for the exceptional growth between 1947 and 1973 were described in books published by two main collaborators of the Geneva Association'.

1973 was then the start of a new era in the long history of the insurance business. We had maintained from the very beginning that because of the important changes in the overall economy, insurance was emerging as a key

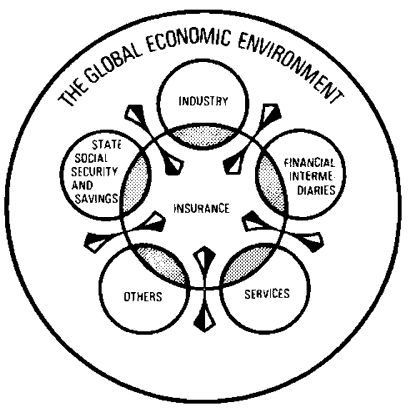

The Research Interfaces economic factor (from its secondary role during the period of the industrial revolution) to be fully integrated into any overall strategy for economic development ${ }^{2}$. The central thesis

\footnotetext{
${ }^{1}$ See the "Diminishing Returns of Technology" by Orio Giarini and Henri Loubergé, Pergamon Press, Oxford, 1978.

2 The first explicit document on these lines was the Lettre d'Information, No. 19, of the Geneva Association, March 24th 1975, entitled "Economics, Technology and Vulnerability (L'economie du risque et de l'assurance)". This text was republished in the Geneva Papers, No. 6, October 1977. See also: Etudes \& Dossiers, Nr. 3, "Introduction to Economy, Risk and Security", March 1976, as well as the articles on our basic ideas published simultaneously in Le Monde, La Stampa, Die Welt and The Times in their joint supplement of November 4th, 1975.
} 


\section{The Aims of The Geneva Association}

The International Association for the Study of Insurance Economics, called "The Geneva Association" was founded under the initiative of a committee which met for the first time on September 22, 1971 in Paris. This founding committee included: Mr. Emil Frey, General Manager, Mannheimer Versicherung (Mannheim); Mr. Georges Martin, President, Royale Belge (Brussels); Mr. Ernst Meyer, General Manager, Allianz (Münich); Mr. Fabio Padoa, Administrateur Délégué, Generali (Trieste), and Mr. Bernard Pagezy, President, Paternelle (Paris).

The Constitutive Assembly of the Geneva Association took place in Paris on February 27, 1973, at the headquarters of La Paternelle (today part of the AXA Group). The following companies were represented by their President or Chief Executive Officer: Allianz, Münchener Rück, Aachener \& Münchener, and Victoria for Germany; Commercial Union, Royal and Mercantile \& General for the United Kingdom; Erste Allgemeine for Austria; Royale Belge for Belgium; UAP, AGF, Paternelle, Préservatrice and SAFR for France; Generali, RAS, Reale Mutua, INA and Fondiara for Italy; Nationale Nederlanden for the Netherlands, and the Swiss Reinsurance Company for Switzerland.

A first report to the Assembly of Members in 1974 by the Association's first President Raymond Barre, contained a clear statement of the Association's aims, as follows:

- "The Geneva Association has been founded to make an original contribution to the progress of insurance through objective studies of the interdependence between the economic environment and insurance activities" and this on the assumption that:

- In order to achieve this aim, the Geneva Association shall highlight the role of insurance in the economy and in modern society. For, at a time when the need for security is increasingly acute, it is in the interest of all parties to stand together in facing the growing risks of a changing world." $(*)$

The very design of the Geneva Association's logo brings into sharp focus this priority of concentrating both on these "interface" areas of risk, where insurance meets the risk management problems of its clients in all sectors ("micro-economics") as well as on the uncertainties of the global economic environment ("macro-economics"). For the last twenty five years, the Geneva Association has constantly followed these main goals by setting up various types of research activities at these "interfaces".

At the outset, the Geneva Association had twenty members in eight European countries. It now has eighty members in all five continents, including fifteen countries in Europe and four in North and South America. Its members are the chief executive of ficers of most of the leading insurance companies in the world, although they are members in a personal capacity.

(*) Article 2 of the statutes defines the aims as follows: "The object of the Association shall be to study and analyze the problems relating to insurance economics at the international level by means of:

a) Research

b) Organization of international colloquia on topics of great interest for the development of insurance

c) Publications.

The Association can take any measure and engage in any activity that may be useful to achieve its objects." 
was that the management of vulnerability (i.e. of pure and insurable risks) had become a fundamental strategic element of economic management, at both the macro and micro levels because of the growing complexity of the economy and as a consequence of using technology of increasingly high order of sophistication.

The notion of vulnerability itself extended from the industrial system to the social system and has finally reached out to affect the types of economic growth conceivable for the future.

\subsection{The new image of insurance: Becoming a key strategic issue in the contemporary economy}

For decades now, the insurance industry has been complaining about the low profile in public opinion of this branch of economic activity. Great efforts have been made to try to improve the image of insurance with a growing-even if still inadequate rate of success.

Many misunderstandings must still be removed: this situation is not due to any lack of willingness or capability on the part of insurance companies and associations to improve and refine their operations in meeting customer needs and wider public expectations.

The fundamental reasons for such a situation are rooted in certain key paradigms or basic assumptions of traditional economic and societal culture which are still strong enough to impair our perception of the real importance of insurance and of its risk management role.

Fortunately, these basic assumptions are now beginning to alter radically. Accordingly, a new image of insurance is emerging which should, over the next decade, completely change traditional attitudes and perceptions of the field. It was indeed a similar change in perception that 25 years ago inspired the founding fathers of the Geneva Association and which today is at the core of our long term strategy and fundamental research.

We can only make brief mention here ${ }^{3}$ of the basic assumptions just referred to which still permeate our economic and societal culture. They may at times appear to be rather theoretical, but it is they, frequently by implication, that determine the overall view of insurance in the mind of both laymen and specialists within the economy and society at large.

First of all, it should be remembered that economic theory (on which economic analysis is based) initially came into being as a consequence of the industrial revolution. It was industrial development which stimulated and therefore conditioned economic thought. Since Adam Smith, the wealth of nations has been equated with the amount of material goods, which the manufacturing system was capable of producing. It is understandable, therefore, that everything not directly connected with the production process itself, i. e. services (or, in economic terms, the tertiary sector) has been studied with less interest and all too easily regarded as merely ancillary to that process. Every student in economics today still leaves university with some knowledge of Engels' law according to which insurance is bought and used only after basic needs (such as food and shelter) are satisfied. Such ideas are still propounded, then, in an age when, especially in the high technology field, access to an insurance system is deemed essential to rational decision-making in investment and production. That today insurance, along with many other service activities,

${ }^{3}$ For more details see: The Geneva Papers, Nr. 48, July 1989 on "Risk and Society". 


\section{KEY STRATEGIC ECONOMIC ISSUES FOR INSURANCE}

\section{The Pricing Practice of Insurance as a Key Reference in the New Service Economy}

In classical industrial economics, prices are normally fixed by reference to production costs in meeting a solvable demand.

By contrast, the insurance experience has always been that of a "reversed cycle" in which a price has to be fixed on the basis of an uncertain event happening in the future.

Today, increasingly, pricing systems have begun to resemble insurance policies and are moving away from the traditional simplified "industrial" price-fixing model. Indeed, some of the costs occasioned by product or system utilization (including waste disposal) require a judgement at the moment of selling which comes closer to the way an insurance manager thinks and acts. This is particularly obvious in the case of leasing. Expansion of liability costs for products and services has thus become a way of incorporating the future performance of products and systems as a factor in the calculation of the "costs of production".

While classical industrial economics could aim at a "perfect equilibrium" for prices, given adequate information, in the Service Economy the notion of uncertainty is an integral part of both practice and theory. Prices increasingly reflect a probabilistic judgement on the future costs of utilization. In such circumstances, no "scientific" information could ever generate what is thought as "perfect" information. Economics needs to look closer at how insurance price systems work.

is manifestly a precondition for, or factor of, production is not something generally recognized either in economic theory or public perception even though it is a fact readily verifiable in practice. The growing perception of the contemporary economy as a service economy will have a decisive impact on economic culture as a whole in this respect. This is why the Geneva Association has been at the forefront to contribute to the worldwide discussion on the "new" service economy.

The second main reason for the traditionally low profile of insurance in economics has been described by Irwing Pfeffer. ${ }^{4} \mathrm{He}$ shows how the analysis of risk, particularly of insurance risk, requires a dynamic analysis framework, whereas economic theory has in most cases chosen a static method of analysis. Static analysis purveys a sense of precision, that one is dealing with determinate systems. As as consequence, economic theory is founded on the notion of "general equilibrium" which excludes uncertainty and risk by definition. Economics has in this way pursued the dream of becoming "scientific" as physics was supposed to be. But since Einstein, even for "hard" sciencies, "God appears to play with dice" and, worse still, since Heisenberg, the ultimate physical reality has become "indeterminate". Moreover, when explaining nuclear reactions a physicist once said: "It is like managing an insurance company".

4 "Perspective on Insurance", edited by Prentice Hall, New Jersey, 1974, and "Insurance and Economic Theory", edited by Irwin, Homewood, Illinois, 1956. 
We are today about to witness important changes. The notions of uncertainty and even of indetermination are now established at the core of hard sciences, and as a consequence, a dynamic vision of economics, through the integration of uncertainty in its models, is opening up the way for greater interest in insurance activities which in many ways are prototypes of this new economics of uncertainty.

The above point is not only relevant to the issue of dynamic, as opposed to static, methods for evaluating economic systems, but reaches out to link up not only with the broader question of society and the challenge of life's uncertainty but also with some basic philophical assumptions of our culture. In fact, behind the dream of a deterministic science aiming at total certainty, which was typical of last century, lies another human dream, that of combating the natural uncertainties of human experience by recourse to systems which claim to provide ultimate certainty. We find a version of this attitude also in more current economic theory where increasing reference is made to the notion of "incomplete information". The point is that any information which has to do with events that occur in the future is by definition incomplete and can only be approached by reference to various levels of probability. No information, when it has to do with real time, is ever complete. It is, on the contrary and by definition, uncertain and at best only highly probable. Human behavior and a fortiori economic activity, can therefore only be based on decisions which are themselves subject to different levels of uncertainty. No "scientific" method will ever provide certainty. It becomes clear, then, that, in setting premia with an eye to a probable distribution of future events, insurance companies are providing the contemporary economy with a paradigm of dynamic management.

Uncertainty and/or incomplete information can therefore never be synonyms of imperfection; they are just a fact of life.

Acceptance of these principles as fundamental canons of societal philosophy depends on the prevalence of indeterministic philosophies over those of determinism5.

The above issues may appear a touch over philosophical and theoretical. But implicit in any human attitude or action is always a fundamental theory. And the very complexity of modern life and of our economic systems is in itself a challenge to our culture to face risk and uncertainty squarely rather than attempt to avoid them by constructing for ourselves a fictitious world in which they play no part 6 .

On a more practical level, the rising tide of interest in risk management, which started over twenty-five years ago, is a clear indication not only of the emergence of new problems and of new career possibilities, but also of a fundamental change in basic attitudes as to the problems of risk. In any event, the key issues currently under discussion, for example pollution and environmental questions, the vulnerability of industrial systems or the growing concern with liability and other similar matters will point towards the desirability of developing insurance as a key tool in the management of current economic reality.

${ }^{5}$ See for instance Karl Popper: "The Open Universe: An Argument for Indeterminism", Hutchinson, London, 1982.

${ }^{6}$ It is also interesting to note that some insurance companies are becoming less afraid to evaluate their activity by reference to the philosophical perception of risk in society. See, for instance, "Society and Uncertainty", edited by the Bayerische Rückversicherung AG, Munich, 1987. 


\section{SCIENCE AND UNCERTAINTY}

Until the beginning of this century, science was presented as a possibility to produce results, which could be considered as certain and universal. The advancement of science was seen as a way of eliminating risk and uncertainty. Therefore, on a cultural level, insurance could not achieve adequate recognition, because it was assumed that sooner or later, its activity would have become unnecessary thanks to the growing application of "scientific methods" in all sectors of society.

For the last six to seven decades, scientists have progressively adopted another view, accepting the idea that science is a way of managing uncertainty through progress of knowledge and not of eliminating uncertainty. The notion itself of uncertainty and risk management, which once was considered as a sign of imperfection in our society, has moved to the center of the picture and now there is no fundamental, philosophical or cultural reason to deny the key role of insurance in this area.

We have tried, with some success, to promote this view through publications, meetings and lectures with top scientists. The contributions from Nobel Prize Winners like Ilya Prigogine, and from scientists such as Karl Popper, Hermann Bondi, Walter Weisskopf and many others, have confirmed that this was in fact a key basic issue.

Referring to one of our publications, Prof. Ephraim Katchalski-Katzir, President of the Weizmann Institute, has written to us as follows: "...I read your book on "The Limits of Certainty" $(*), \ldots$, with keen interest. In the book you have succeeded in transposing uncertainty from physics into economic thinking in a most lucid and convincing manner. Your analysis of the importance of risk-taking in a modern economy, and discussion of the roots of uncertainty are particularly illuminating. You should be congratulated for carrying out a fine and impressive analysis of the risk involved in many of the steps taken by individuals and society, and for indicating that in the new era that we live in, we have no choice but to cope adequately with the various facets of risk which face us...".

(*) "The Limits to Certainty - Facing Risks in the New Service Economy", by Orio Giarini and Walter Stahel, second edition, Kluwer Academic Publishers, Boston, 1993.

Audacious in formulating hypotheses, merciless in its scrutiny of them, the role of the Geneva Association, typical of fundamental research, is at once both modest and inspiring. It is our priviledge to be able to serve the expanding and increasingly complex world of insurance with its growing impact on contemporary economy and society.

\subsection{From "limits to growth" to "limits of state intervention"}

It was possible, during the great economic growth period, to pursue several objectives at the same time: full employment, increase in social security, expansion of investments, 


\section{KEY STRATEGIC ECONOMIC ISSUES FOR INSURANCE}

\section{Ad Astra per Aspera: Insurance at the Center of Modern Economy}

Over the last 25 years, insurance has undergone, if not rebirth, at least a fundamental revolution. It has become an essential pillar of all major (economic policy and development) problems and issues:

- Insurance has become the essential complement to all social security and savings policies.

- Insurance provides key professional methods for the assessment, identification and management of technological, industrial and environmental risks.

- Insurance is an essential complement to any health policy.

- Entrepreneurial risk itself is increasingly conditioned, in all sectors, by adequate understanding and control of pure risk.

The following figures for the global world growth of insurance over the last four decades, which is normally above by $1 \%$ the average rate of growth for national income, deserve careful consideration:

\section{Annual World Premium Growth}

1950- 1995

\section{Nominal Real \\ $10.5 \% \quad 4.9 \%$}

(Source: SWISS RE, Zurich)

One should also note that these statistics do not cover the entire range of insurance activities developed by other institutions and "non-insurance" companies.

control of inflation and the utilization of budget deficits essentially to meet economic fluctuations in the short term.

All this is now in the past and economic policy-making in all countries is increasingly hedged about by difficult decisions and uncomfortable choices. Increasingly, the art of government is becoming bound up with the problems of identifying and handling limits, including those of State intervention itself. Inevitably, at first, the economic situation seemed to call for strong State intervention in order to counter the dangers facing threatened social, economic and industrial sectors. In general, this intervention was merely transferring to State level a growing number of vulnerabilities which, through a process of accumulation, would end up by becoming a destabilizing economic factor to the State itself. 
Following the crisis of the centrally planned economies throughout the world and their adjustment to new conditions of economic development, it is also clear that the notion of and need for State intervention are under closer scrutiny. The task of defining those areas where private action, as distinct from public activity or regulation, is most suitable clearly calls for new concepts and an entirely fresh strategy if acceptable and manageable solutions are to be found. Then it would appear to be no longer any justification for basing the distinction between private and public activities on the premises of existing political ideologies. It is, on the other hand, equally clear that sooner or later the growing vulnerability of our economies will induce economists and politicians to understand and define the notion of insurability. In a technical sense, that which is insurable should normally be developed in complete freedom. However, it must be admitted that not always can the degree of insurability be clearly established and that sometimes a flexible margin of adjustment becomes inevitable.

But it is also obvious that any activity which is not "insurable" inevitably requires some measure of State support and incentive. It is then in terms of the layers of insurability (which can be levels of partial and of total insurability) that a new strategy for private and public complementarity appears to be emerging.

The growing importance for any type of economic policy of determining insurability levels is just one facet of the emerging new role of insurance itself. Another has already been referred to; it is pricing practice in insurance and in the "Service Economy".

Crucial among the social economic factors is the type of manager and perception required to handle vulnerabilities. It is frequently asserted that insurance should "modernize" by adopting industrial methods. If by industrial methods we mean being "professional", "precise", and "down to earth" in our approach to management practices and rigorous in all we undertake, then well and good. But it should be remembered that in the matter of pure risk and insurance management there are specifics which should never be confused with what is proper to "industrial" activities. The function of the industrial entrepreneur is to promote new markets and opportunities. The fundamental function of the insurer is first and foremost to select risks. This latter function is the hallmark of the "progressive", modern insurer and has far reaching consequences. When industrial managers have to handle pure risks, they have to begin thinking like insurers.

Ultimately also this rule applies equally to money management in the short and longer term. Contrary to what is so often stated in speeches and writings, the modern economy is increasingly confronted by the growing problem of how to adjust to long-term issues - fundamental research requires decades before yielding results and development research many years; developing a distribution network also takes many years; the control of future risk is something that spans decades as do the key issues of environmental protection and the long term consequences of current investment and consumption; and most long-winded of all is the elaboration of social policies affecting the lives of people who start work in their 20 's and retire only when they are 60 or 70.

"Long term" thus becomes the key qualifier and concept here, something with which all insurers are familiar by reason of their professional experience. 


\section{KEY STRATEGIC ECONOMIC ISSUES FOR INSURANCE}

\section{Insurability: \\ The Key Issue at the Frontier Between Private Activity and Public Intervention}

Given the present relevance of risk management and insurance to all economic activities, it is increasingly important to understand that a key condition for activity in the private sphere, is the ability to reach a reasonable level of insurability.

When the level of insurability of any type of economic activity is clearly exceeded, then government or society at large must step in.

It is at the frontier of the insurability of private endeavors that government will have to consider carefully the manner of its intervention.

As such, in future years, the notion of insurability could well become a key reference for the development of a society whose purpose would be to achieve maximum freedom for all while being run on sound managerial principles.

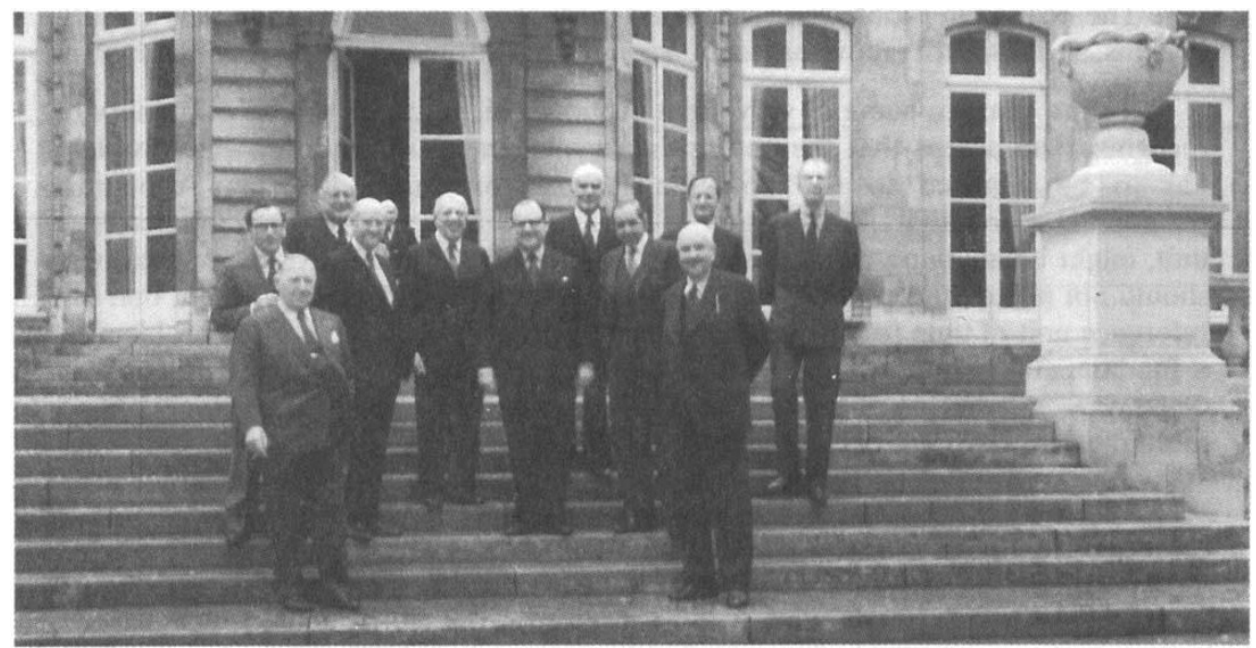

The Board of the Geneva Association at the "Hotel Matignon", residence of the Prime Minister of France (1977). From left to right: W. Diehl, G. Martin, H. Vischer, J. Neave, F. Padoa, R. Barre, P. Romagnoli, J. Argüelles y Armada, H. Urbanski, B. Pagezy, G. Aarestrup. 


\section{The Insurer: The Guardian of Adequate Reserves}

It is often said that when an entrepreneur in industry says "yes", he means "maybe", that when he says "maybe", he means "no", and when he says "no", it means that he is not really an entrepreneur. In other words, the entrepreneur in an industrial system must always be ready to evaluate any project as a possibility and in his search for new markets or endeavors only step back after verifying in detail the opportunities.

The situation of the insurer is quite reverse: he must say "no" at the beginning, in the sense that he must select the risks he accepts according to stringent criteria. Therefore "no" often means "maybe". If he says "no" too quickly he might forego any control over what he is underwriting. Therefore, when an insurer says "maybe", he practically means "yes"; if he says "yes" right away, he is not a good insurer.

Facing a lake, an entrepreneur looks at the water as something to be used and consumed. An insurer looks at the lake and the water in it and wonders just how long he will be able to maintain the water at its current level and whether he will ever be able to raise that level. And if it is a reserve he is looking for, he will want to be sure that the water is going to be there for a long time, for decades even. In other words, the only way to be a progressive manager in insurance is to be very "conservative".

The economic problems in which he is involved, directly or indirectly (health systems, social security, environment), are most of the time of a long term nature.

In the years to come of very great economic significance will be our ability to recognize and accept that the appropriate management of any economic problem has to be adjusted to the optimum lifespan or duration of any economic phenomenon or activity. This optimum duration, to be considered a reference time unit, might be anything from a few years to a decade or more. Economic measures should not make this optimization impossible. And economists must accept that the reference unit of time (one year or one decade or more according to the problem) is a fundamental parameter upon which the economic optimization of a system will depend. The definition of the time span of economic problems will be essential to a more rational fiscal policy. 


\section{The Research Program on Social Security, Savings, Life Insurance, the Four Pillars and on Health Economics}

It is against the background described in chapter 1.3. that the Association commenced its activities by undertaking studies in the sector of life insurance, which examined the latter's interface with social security on the one hand and with households savings on the other.

The research program in this area began by a comparative study of the evolution of savings and group insurance with that of social security.

It should be remembered that when the Geneva Association embarked upon this type of study, in the mid 70s, the predominant view was that social security was a domain entirely separate from private insurance, and that the two ran on parallel lines with little possibility of influencing each other.

\section{Studies on Social Security, Savings, Pensions Plans, Life Insurance and Health Economics}

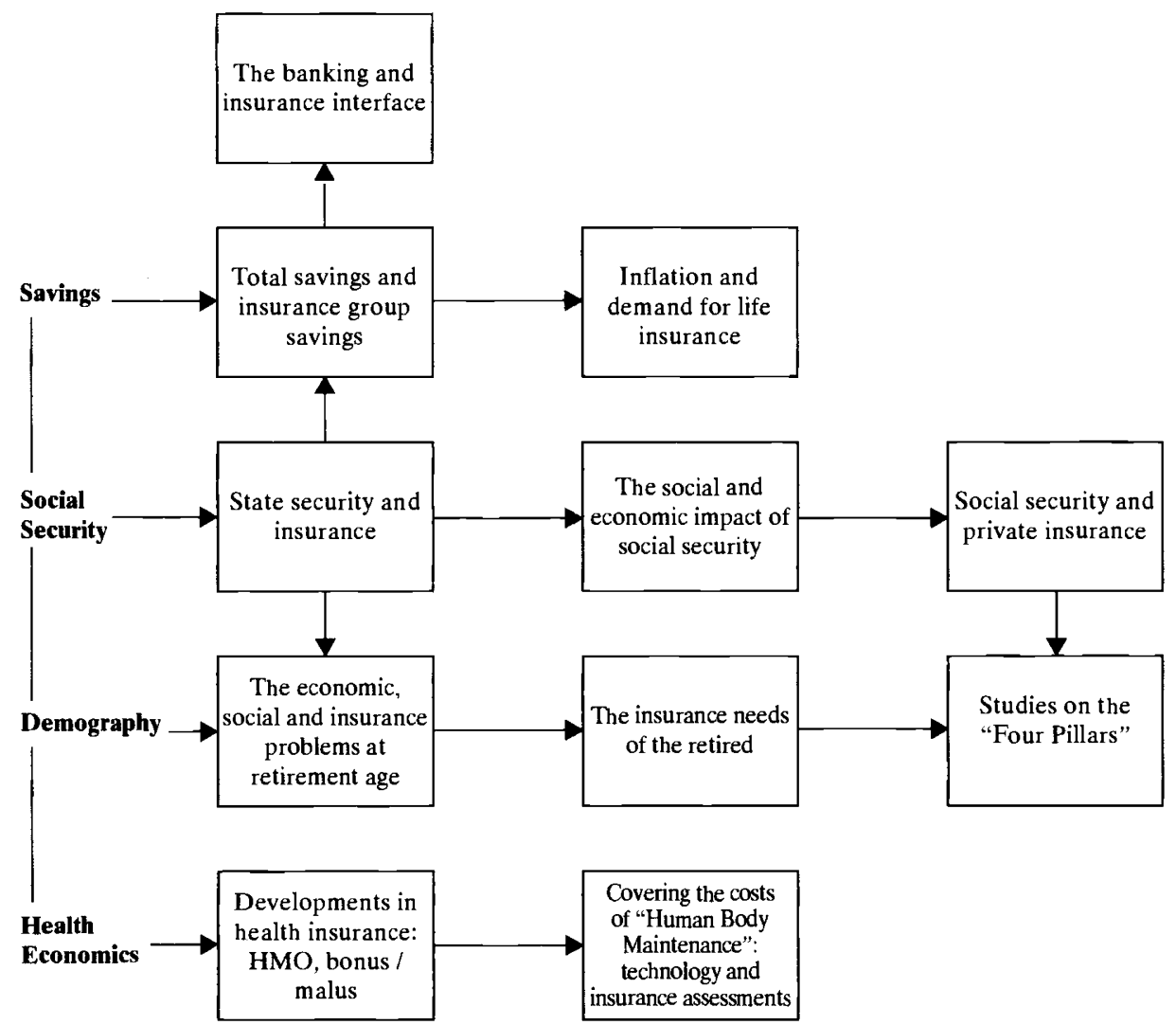


The Geneva Association has spearheaded a general trend which holds that the future organization of security for individuals resides in schemes based on the complementarity of State social security (which normally operates on a pay-as-you-go basis) with capitalization in its various forms. This picture is of course completed by a third component - private and collective savings.

Pioneer studies have been done in several countries. One such study, published in France in 1981, was to have a significant impact. It was the outcome of several years of preparation by two world-class economists, Professors Dominique Strauss-Kahn and

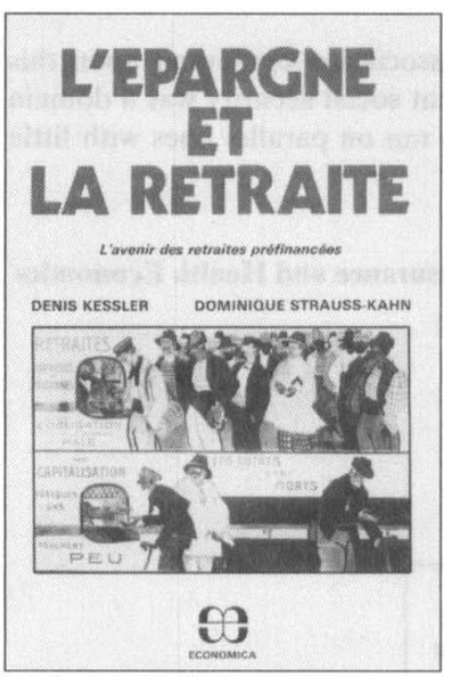
Denis Kessler. The book was published by Editions Economica in Paris, under the title "Savings and Retirement - The Future of Pre Financed Retirement" ("L'épargne et la retraite - L'avenir de la retraite prefinancée"). Particularly because of the personalities of the researchers themselves and thanks to the support of the insurance industry, this book has proved an invaluable tool in France in defining national policy on the development of savings and the role of life insurance.

By the mid 80s, the development of pension funds and life insurance as complements to social security schemes, had become an accepted part of economic thinking and practice, and the Geneva Association was accordingly able to seek fresh horizons for its pioneer work.

It was in 1985 that the concept of the "Four Pillars" was launched. This involved giving serious attention to the far-reaching changes affecting demographic structure and relating the latter to the rapid expansion of part-time work for those over 60 years.

Part-time work can be considered a "Fourth Pillar" for the older population in their efforts to achieve greater financial security and more satisfying integration as active members of society. It is clear that the four pillars are mutually interdependent (state pensions, private schemes, direct savings and income from part-time work). Both practical initiatives and changes to legislation (starting in particular in Scandinavian countries) have produced interesting new approaches in this field. The problem has become very acute at the end of this century when the "baby-boom" started to increase considerably the percentage of people over 60 in Europe, the United States and Japan within the total population. The current baby-boom in developing countries elsewhere in the world will clearly present the same type of problem two or three decades later but on an even larger scale.

The manner and rapid pace of the expansion of part-time work for older people will undoubtedly have important consequences for insurance markets in several branches. Another positive development might be that people over 60 will constitute a knowledge and skills reservoir to drawn on in realizing newly targetted insurance marketing programs. 
Much will depend on the quality and quantity of this new labour pool of workers as also upon their willingness to work part-time. Much as well will depend on the evolution of fiscal policies and on numerous other factors.

It is also worth noting that the Geneva Association has underlined the close link between the potential for developing part-time and flexible jobs and the increasing share of services in all sectors of the economy? ${ }^{7}$. This has relevance to our research in this area, not only because of what will happen in the next century, but also because of the potential of part-time jobs as one possible solution to unemployment. The relevance of this approach is, for instance, being borne out by the findings of the Association's study on this issue in Germany.

The concept of the "Four Pillars" is now fairly well-known in Japan, has been cited for several years now by the Employment Benefit Research Institute in Washington, and was also mentioned in a for the first time report of the European Communities published in $1992^{8}$.

Given the very limited resources of the Geneva Association, we have not conducted in depth studies across the entire field but have been concerned to promote the idea of the "Four Pillars" as a constructive and viable focus studies straddling vast research domains like demography, education, employment, social security, savings, etc... Since 1985, many seminars, conferences, and joint activities with various other research organizations have been undertaken on different aspects of these issues.

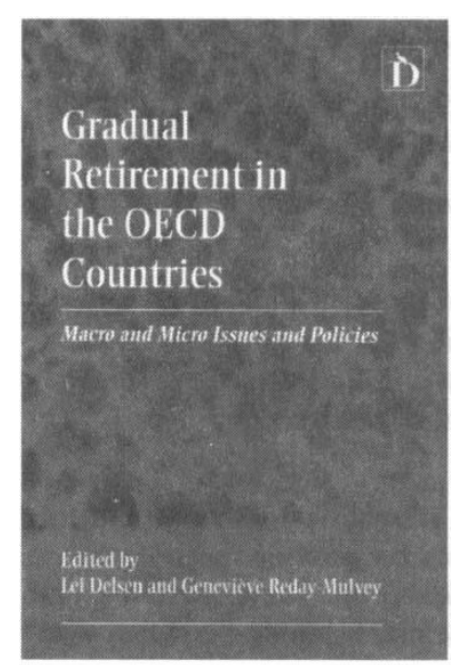

In this area also, the Geneva Association has achieved one very tangible result, this time in Germany, with a study pioneered in that country in 1988. The study showed that the creation of a "Fourth Pillar" is necessary to ensure the long-term financial viability of old age pension systems. The essential features of a "Fourth Pillar" include an early-announced but gradual raising of the normal retirement age limit and the introduction of a partial pension combined with a gradual transition from working life to retirement as a means of ensuring in practice implementation of such an increase in age limits. The study did not set out to define or stipulate the details of the way a fourth pillar would operate. Rather, the intention was to identify the problems, so that it would become clear what questions needed answering, what areas required further research and what steps would have to be taken in order to ensure that a "Fourth Pillar" is a success.

${ }^{7}$ See also "The Employment Dilemma" by O. Giarini and P. Liedtke, published in Spanish by BBK, Bilbao in 1997 and in German by Hoffman und Campe in 1998.

${ }^{8}$ See also: "All the people in Europe: Social and Economic Policies", the 1993 Report of the European Observatory, Commission of the European Communities, Brussels, 1993. In this report, the fourth pillar is integrated in the revenue of the population over 60. See in particular: Table 2.1. of this report. A special study on this issue was also commissioned in $1996-97$ by the Swiss authorities to Mrs. Geneviève Reday-Mulvey, our head of project in this area, who also contributed to a recent commission formed by the European Community in Brussels on these very same issues. 
It is doubtless a rare, not to say miraculous, occurrence when the ideas of experts' coincide with the proposals of law-makers: such a miracle has occurred in Germany !

A first bill presented in March 1989 reformed Germany's statutory old-age pension scheme. It was sponsored not only by the government coalition, but also by the larger opposition party, the SPD, that is, by a broad parliamentary majority. The draft bill contains a whole series of reform measures, but three in particular may be said to put into practice what the Geneva Association has always maintained is meant by the term "Fourth Pillar".

First, the age limits, which today are 60 and 63 years for women and men respectively, have been raised in stages to 65 years between the year 2001-2012 - for both sexes - so that the difference in age limit for men and women will have been finally abolished by 2012 .

Secondly, the age limits are not treated as rigid limits. People have the option of drawing their pension both earlier or later, although early pensionable retirement will be limited to three years. The important new feature compared with the previous provisions is that an old-age pension which is drawn early is reduced by an actuarial deduction, viz. by $0.3 \%$ per month, so that it is reduced by $10.8 \%$ if drawn three years earlier. On the other hand, for every month that a senior citizen postpones drawing his or her pension after the age of 65 , the benefit is increased permanently by $0.5 \%$.

Thirdly, beneficiaries are also be able to draw partial pensions in place of the full pension and will at the same time be able to do a part-time job.

In November 1989, the West German parliament adopted the 1982 "Pension Reform Act" which is now effective9. Further, a "Pension compromise" has adopted in 1996.

In the very important sector of Health and Insurance Economics, the Geneva Association has developed to the following issues:

- A seminar organized in collaboration with the "Institut La Boetie" in Paris, and with the contribution of European and American experts on "The Experience of HMOs in the United States and the Developments of Health Insurance in Europe" in Paris in December 1986. This subject is being dealt with further in articles published in "The Geneva Papers".

- A special session on "Risk Choices in Medical Decision Making" published in the July 1986 issue (Nr. 40) of "The Geneva Papers" and followed by another special issue on "Problems and Perspectives of Health Insurance", published in "The Geneva Papers" Nr. 45 (October 1987) with an introduction of Prof. Dr. Reimer Schmidt.

- The Board of the Geneva Association in it's 1994-95 sessions, has decided that the study on key issues in the health insurance sector be placed on the list of top 5 issues to be researched by the Geneva Association. This recommendation was approved at the 1995 and 1996 General Assemblies of the Geneva Association.

${ }^{9}$ See "Changing the Retirement Age in Germany", by Winfried Schmähl, The Geneva Papers on Risk and Insurance, $\mathrm{Nr}$. 62, January 1992, pages 82-104. 
General Assembly in London (199I): Mr. Maurice Greenberg, President of the A.I.G., New York, lecturing on the future of insurance.
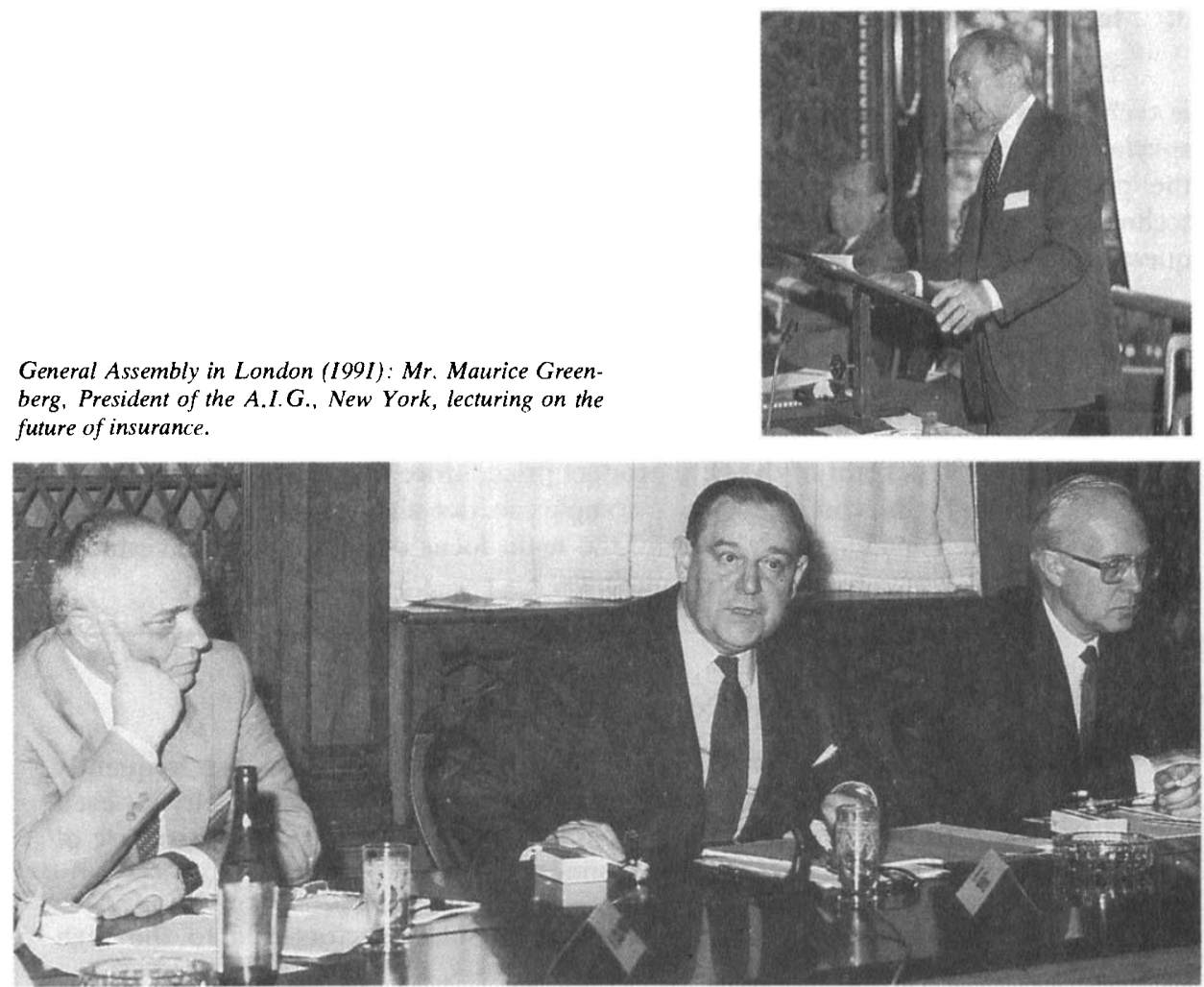

General Assembly in Venice (1983): Prof. U. Colombo, President of ENEA, Rome (Italian Agency for Energy and Environment, new Minister of Science and Education); Prof. Raymond Barre, Dr. Helmut Schlesinger, President of the German Central Bank.

The first initiatives included the organization of a number of seminars and lectures: The first was on "Workers Compensation" (papers published in the July issue, (no. 84) of the Geneva Papers). The second was a conference organized in London on "Strategic Issues in Insurance" on October 21-23, 1997 (papers published in the Etudes et Dossiers, (no. 217) of April, 1998). In order to collect information and confront new ideas in health economics, a regular series of seminars on research in this area are now planned under the general title of "The Future of Life and Health Insurance". The first of these seminars is planned in London on September 24, 1998. The second will take place in Paris on October 27 and 28, 1998 and the third in Geneva on November 24-25, 1998, with the collaboration of insurance experts, researchers in Health Economics, experts from international organizations such as the WHO (World Health Organization) and the International Labour Organization, both in Geneva, representatives of the chemical industry, prosthesis manufacturers, and experts from the medical industry.

More specifically, the Geneva Association is developing a deeper study concerning the maintenance of an active life after 60 (see page 462). 


\section{Industrial Development, Technology, Risk Management and Insurance}

Technology has been the key development factor of the Industrial Revolution. For it is technology that has engendered new materials, products and processes, and, through specialization and economies of scale (including higher production speed), has increased the productivity of the manufacturing process. It is this very same development of technology that has now shifted the focus of economic progress to service functions, in the quest for increasing the wealth of nations ${ }^{10}$.

In fact, if we look at all sectors of contemporary economic activity, we can see immediately that services of one kind or another represent the essential part of the production and delivery systems of goods and services. In any product we buy, be it an automobile or a carpet, the actual cost of production or of manufacture is very seldom higher than 20 to 30 percent of the final product price. More than 70 to 80 percent of that pricell is taken up by the cost of making a complex service and delivery system work. This means that service functions have become the main focus of concern and investment in even the most traditional of industrial companies.

\section{FACING UNCERTAINTY}

Development of specialization has multiplied the classes of risk but frequently also has reduced the possibility of building a minimum level of homogeneity for each of them. The efforts of actuaries to develop credibility theories on this issue are of fundamental relevance for insurance economics.

The frequency of events has diminished in many sectors due to the high reliability of modern technology.

Moreover, because of the growing complexity and size of systems and their increased vulnerability(*), the gravity of damages and disruption has also greatly increased. All these phenomena have contributed to raising the overall cost of risks and damages in the modern economy, and made this problem into a key issue for industrial and environmental-friendly development.

(*) vulnerability does not refer to the bad functioning of technology, but to a specific constraint: for the most part, advances with technological systems imply a reduction in the capacity of their functional performance (i. e. margin of tolerance) to respond or adjust to changing conditions of operation.

$10 \mathrm{On}$ the link between technological and industrial developments, see: Orio Giarini and Henri Loubergé, "The Diminishing Returns of Technology", Pergamon Press, Oxford, September 1978; Orio Giarini and Henri Loubergé, "Cycles, Value and Employment", Pergamon Press, Oxford, 1984.

${ }^{11}$ See in particular the very detailed study done in Germany by Wolfram Gruhler on "Dienstleist ungsbestimmter Strukturwandel in den Deutschen Industrieunternehmen", Deutscher InstitutsVerlag, 1990, Cologne, 410 pp. 
It is therefore clear that the service economy is in no way in opposition to the industrial economy, but merely represents a more advanced stage in the process of economic history. The real shift from an industrial to a service economy is evidenced by the fact that services are becoming essential to the business of ensuring that products and services meet basic needs. The service sector has ceased to be a secondary sector and is now moving to the forefront of economic activity where it has become an indispensable production tool in satisfying basic needs and in increasing the wealth of nations.

The connotations of risk in the service economy are much broader than the notion of risk familiar to the Industrial Revolution. In the latter case, the key risk normally referred to is so-called entrepreneurial or commercial risk; in the service economy, this notion broadens out to include so-called pure risk, the stamping-ground of risk managers and insurers.

It is in the context of pure risk that the notion of vulnerability which covers the possibility of breakdown or malfunction of a given system has become fundamental. Modern technology has rendered the problem of vulnerability very acute, not because the technology is bad, but precisely, and this is the paradox, because it is very good. The frequency of risk tends to be extremely low, but exposure reaches higher and higher levels. Airplanes crash very rarely whereas stagecoaches were likely to have breakdowns every 30 miles or so. But which of these two vehicles is the more vulnerable? In the case of a stagecoach, a broken wheel is not too serious, but when a window of a jet opens in flight the results are catastrophic.

This is a clear indication of the fact that we have now entered an age of highly efficient technology in which although accidents are rare, we are confronted with an economic problem, that of managing vulnerability, something that was of little concern to the owners of coaches during the reign of Louis XIV.

Advanced technology, then, brings a vast reduction in frequency but creates enormous problems. In insurance, we are increasingly faced with the diabolical conjugation of low frequency of accidents and great magnitude of damages, which makes such risks increasingly difficult to manage, in a growing number of cases, even uninsurable.

The more advanced and complex a technology, the narrower the tolerances and margins of error become, because of the extremely high costs and far-reaching consequences of any malfunction.

The strategic sphere of modern insurance thus coincides with the management, prevention and financing of this vulnerability.

Trends in the civil liability market, and in particular that of liability for products and services, acquire new meaning in this context.

In studying the impact of new technology on industrial production and distribution systems on insurance, various lines of research have been opened in the new sectors of technology with the aim of taking stock and quantifying the prevailing situation, identifying sector-specific risk and vulnerability types and predicting possible trends for the future.

Research into this industry/insurance interface requires the contribution of professional research centers in the industrial sector. The Geneva Association called upon 
specialist entities with a world-wide reputation such as the Stanford Research Institute, Diebold, Battelle, Gira, Technomic Consultants and others. By closely following the work carried out by these professional institutions, the Geneva Association has created a bridge between industrial research and insurance around the notion of vulnerability and risk management.

It is highly characteristic of the modern "post-industrial" society that risk management (the management of "pure", insurable risks) has become strategically as important as the management of the "entrepreneurial" risk. This is a consequence of the growth of complexity and vulnerability in the economy.

At the very beginning of its activity in 1975, the Geneva Association conducted an initial enquiry with around sixty industrial companies in Europe, in order to find out what were their perceptions of the problems of controlling pure risks and vulnerabilities. ${ }^{12}$

This report was used as an introductory document for the first congress of the European Association of Risk Managers (Association Europeenne des Assureurs de l'Industrie) which took place in Bruges (Belgium).

The Association then established the practice of studying every year, or every other year, a specific sector of industry, where important changes in pure risk and vulnerability were felt to be taking place. The first of these studies, in 1975 and 1976, concerned the losses linked to the utilization of computer systems in various industrial applications. This study again was a "first": 3000 copies of the reports were requested for distribution throughout the world. Since then, the sector in question has been the object of many detailed studies and has become a market per se. The Geneva Association has therefore moved to other frontiers, for example, in the packaging industry and superconductivity.

Concerning the specific types of insurance cover in the industrial sector, the Geneva Association made an other pioneer study, this time, in the sector of "recall practices"13.

Specific studies and seminars have also been organized on issues connected with consequential losses and product interruption ${ }^{14}$.

Over the last eight years, an important line of research has been added concerning the "Comparative Liability Procedures in Europe and in the United States". It first started with a research team organized in Germany and in Great Britain, which has since been extended to other countries, including the United States. The result of the last phase of this work has been available since March 1993, in a book entitled "Personal Injury Compensation“, edited by Werner Pfennigstorf and published by Lloyd's of London Press.

It should to be noted also that the 1980s have been a special period for a networking process including all those involved in coping with the increasing levels of vulnerability

12 The result of this study were published in The Geneva Papers on Risk and Insurance, Nr. 2 , August 1976.

${ }^{13}$ The study was published in Etudes \& Dossiers, Nr. 50, September 1981 (228 pp.) and was reviewed in Etudes \& Dossiers, Nr. 72, September 1983.

${ }^{14}$ The first survey on this issue in the chemical industry was published in The Geneva Papers on Risks and Insurance, Nr. 81, July 1978. 

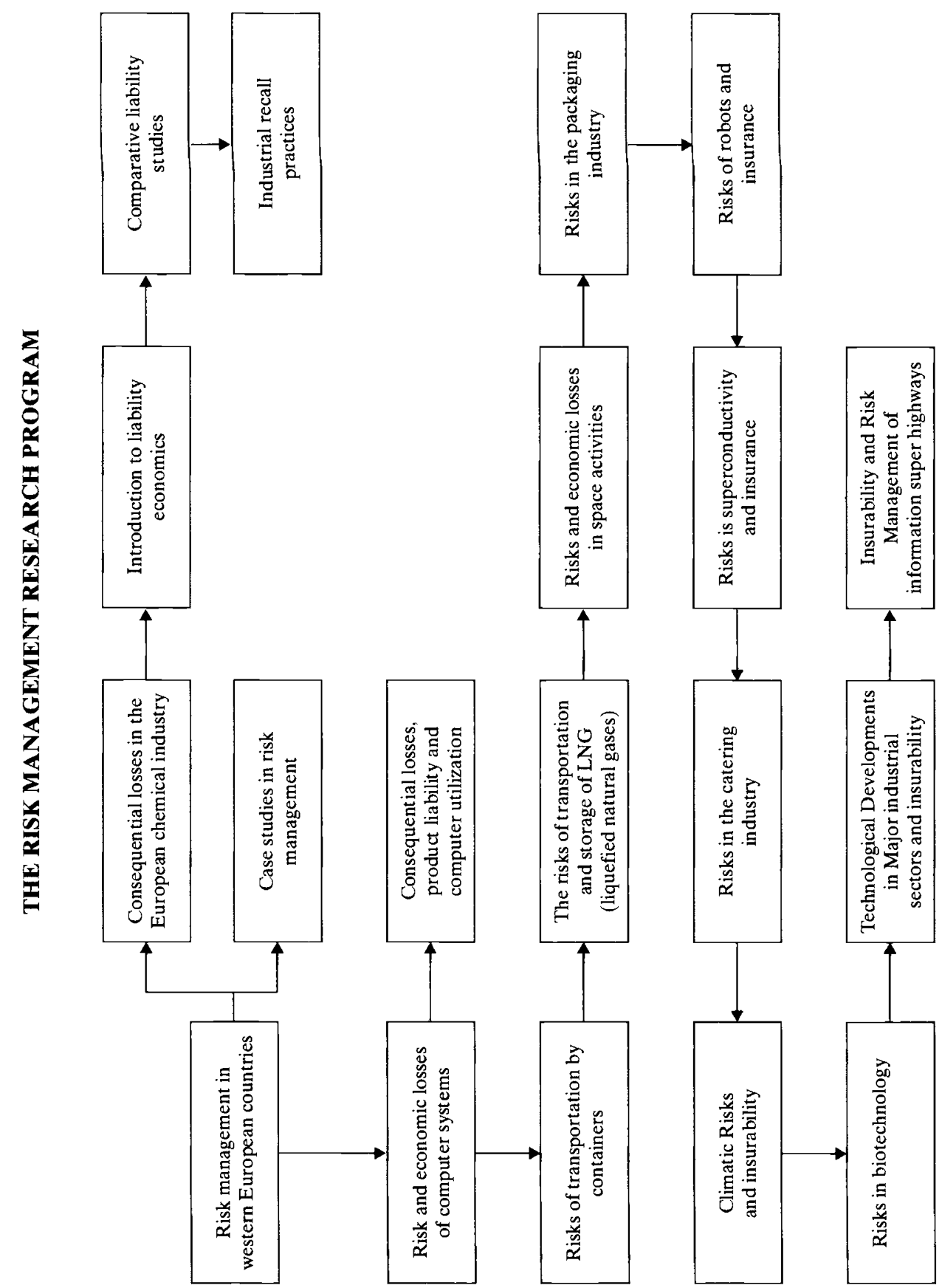
and risks in the industrial processes utilizing modern technologies as well as their societal implications. There has been a clear maturation bringing together engineers, scientists, industrial experts as well as risk and insurance managers.

At the highest intellectual level, we have contributed to the extension of the activities of the International Science Policy Foundation in London, which includes some of the most prestigious names in science. We have contributed to the creation of a European section of this Foundation, for which the Secretary General of the Geneva Association has acted as Provisional Chairman in the launch period. The Former International President of the ISPF, Sir Hermann Bondi, has in fact contributed as first speaker together with Sir Brian Corby, at a seminar organized by the Geneva Association at Lloyd's on June 10 and 11,1987 . This was the first of a series of seminars on "Risk and Society".

During the same period, the S.R.A. (Society for Risk Analysis), a well-established organization based in the United States, also founded a European Chapter, whose secretariat has been fixed at the TNO in Holland. The Secretary General of the Geneva Association has been part of the scientific committee, together with representatives from research centers and major industries involved in the development of modern technologies. The first meeting of the European scientific committee of this organization was held in Paris, on February 24, 1987, with an introductory lecture by the Secretary General of the Geneva Association on "The Management of Risk and Insurance in the Modern Economy".

After several years of preparation, under the auspices and with the financial contribution of the European Communities, the "European Safety and Reliability Association" (ESRA) was founded in Brussels, on October 22-24, 1986. It includes safety and reliability engineers from major companies, research centers and organizations in Europe. The Secretary General of the Geneva Association presented a paper at the first conference on "Risk Management and Insurance".

We continue our collaboration with the "Risk and Decision Processes Center" at the Wharton School (University of Pennsylvania). Several years ago we had already organized together with this organization a large seminar at IIASA (International Institute for Applied System Analysis) in Laxenburg, near Vienna. This Center provides another opportunity for bringing together representatives in industry, government and insurance from both sides of the Atlantic. Our members have been informed of the meetings and initiatives of this Center, taking place once or twice par year. The Secretary General of the Geneva Association is also a member of the Center's scientific advisory committee.

The scientific community has been preoccupied since the times of Einstein about the necessity of controlling negative outcomes of modern research and technology. It has also been possible for us to collaborate with the International Council of Scientific Unions (ICSU). One example is our meeting on biotechnical risks, organized in November 1991 within the Biotech Conference of ICSU in Bratislava. This coincides with our interest in assessing risks due to new technologies. Meetings on "Risk and Society" have in the past been the result of this collaboration where it was possible to initiate contact and discussion between insurers and scientists in new areas.

Most of the initiatives concerning industrial, technological and science reboted risks are now organized around the "Management of Risks in Engineering (M.O.R.E.) Program". 


\section{Summary of the M.O.R.E. Program of the Geneva Association}

(M.O.R.E.: Management of Risks in Engineering)

The M.O.R.E. - Seminars:

1. RISK AND INSURANCE ECONOMICS EDUCATION FOR ENGINEERS, the First International M.O.R.E. Seminar, held in London, June 17, 1983. Papers were published in Etudes et Dossiers no. 73, Oct 1983.

2. MANAGEMENT OF RISK IN ENGINEERING, 2nd M.O.R.E. Seminar of the Geneva Association, held in London, June 28-29, 1984. Papers were published in Etudes et Dossiers no. 84, Nov 1984.

3. RISK MANAGEMENT AND ENGINEERING, 3rd M.O.R.E. Seminar, held in Glasgow, April 17-19, 1985. Papers were published in E\&D no. 94, Oct 1985.

4. MANAGEMENT OF RISKS IN ENGINEERING, 4th M.O.R.E. Seminar, held at Trent Polytechnic, Nottingham, April 22, 1987. Papers were published in E\&D no. 116, Oct 1987.

5. RISK MANAGEMENT AND INSURANCE, 5th M.O.R.E. Seminar, held in Karlsruhe, Nov. 18-19, 1987. Papers were published in E\&D no. 128, Oct 1988.

6. MANAGEMENT OF RISKS IN ENGINEERING CONFERENCE 1988, the 6th M.O.R.E. Seminar, held in London, October 26-28, 1988.

7. THE DESIGN OF TECHNICAL SYSTEMS, 7th M.O.R.E. Seminar, held at the Swiss Federal Institute of Technology ETH, Zurich, Feb 8-9, 1990. Papers were published in Etudes \& Dossier no. 146, May 1990.

8. THE RISK MANAGEMENT OF AND INVOLVING COMPUTERS AND ELECTRONIC EQUIPMENT, 8th M.O.R.E. Seminar, held at the Business School of the Polytechnic, Liverpool, March 3-4, 1992. Papers were published in Etudes \& Dossiers no. 170, Aug 1992.

9. TRENDS IN RISK MANAGEMENT, 9th M.O.R.E. Seminar, held at The Baloise Insurance company, Basel, Nov 4-5, 1993. Papers were published in Etudes \& Dossier no. 182, Jan 1994.

10. ENVIRONMENT AND INSURABILITY, 10th M.O.R.E. Seminar, held in Paris, Nov 21-23, 1994. Papers were published in Etudes \& Dossier no. 198 and 190, February/March 1995.

11. CONTRIBUTIONS BY INSURANCE TO SUSTAINABILITY, 11th M.O.R.E. Seminar, held in Oslo, Feb 26-27, 1996. Papers were published in Etudes \& Dossier no. 199, July 1996.

12. THE INSURABILITY OF RISKS ON THE INFORMATION HIGHWAY, 12th M.O.R.E. Seminar, held in Winterthur, April 29-30, 1997. Papers were published in Etudes \& Dossier no. 210, Sep 1997.

13. MULTI-FACTOR RISKS, from Risk Management to the Integrated Management of Risks and the Environment, 13th MORE Seminar, held in Hannover, June 11-12, 1998. 
The M.O.R.E. - Studies:

The Teaching of Risk and Insurance Economics for Engineers in the UK, the Scandinavian Countries and Holland, by D. Sutherland; published in "Etudes \& Dossiers" No. 79 and 80, April/May 1984.

3-Year BA Course in Risk Management at the Glasgow College of Technology, presented by Prof. Gordon Dickson and 4 students; available on video cassette (cost SFr. 20.- for non-members).

Risk Management and Insurance, by Wolf-Rüdiger Heilmann, University of Karlsruhe; published in "Etudes \& Dossiers" No. 128, Nov. 1988.

Databank of European University Courses in Insurance and Risk Management. A databank of courses held on computer at the City University, London; published in "Etudes \& Dossiers" No. 177, May 1993.

From April 1989 to January 1998 full issues of the Geneva Papers have been published as result of the M.O.R.E. program:

No. 51 April 89 : Hazardous Waste Management.

No. 53 Oct. 89 : Law and Economics of Professional Liability Insurance (I).

No. 54 Jan. 90 : Law and Economics of Professional Liability Insurance (II).

No. 56 July 90 : Comparative Liability Studies.

No. 58 Jan. 91 : Studies in Law and Economics.

No. 64 July 91 : 1. Risk Management today; 2. Studies on Climatic Change;

3. Managing Risk in the Catering Industry.

No. 76 July 95 : Risk Management Issues.

No. 80 July 96 : Risk Management Strategies.

No. 83 April 97 : Managing Catastrophic Risks.

No. 85 Oct. 97 : $\quad$ Sustainability and Insurability.

No. 86 Jan. 98 : Managing Vulnerabilities.

Books:

Industrial Risk Management: A life-cycle Engineering Approach - Proceedings of a conference at the ETH Zürich; Bernold T. (ed.) (1990) Elsevier Amsterdam, London.

Gli insegnamenti relativi alla gestione del rischio nelle Facoltà di Ingegneria, a cura di Giovanni Azzone e Cristina Masella; published by CINEAS Consorzio Universitario per l'Ingegneria nelle Assicurazioni, c/o Politecnico di Milano, Dipartimento di Energetica, Piazza Leonardo da Vinci 32, I-20133 Milano (1995).

The Risk Management Newsletter is published biannually by the Geneva Association. Subscription is free to all interested parties. 


\section{Strategic Issues and International Economic Aspects of Insurance}

\subsection{The General Assemblies and The Geneva Lectures.}

The General Assembly of Members of the Geneva Association takes place every year. It has always represented the highest and most selected concentration of C.E.O.s from insurance industry in the world for such a single event.

On average, about $60 \%$ of members have always been present at each General Assembly.

At these occasions, key economic issues are presented and discussed with worldknown personalities and key indications and recommendations are provided for the activity of the Geneva Association.

\section{THE GENERAL ASSEMBLIES OF THE GENEVA ASSOCIATION}

The General Assemblies of the Geneva Association took place in:

1973: Paris, February 27th: Constitutive Assembly of the Geneva Association (starting of operations on June 1st, 1973).
1974: Paris
1983: Venice
1992: Madrid
1975: Geneva
1984: Vienna
1993: Vienna
1976: Paris
1985: Oslo
1994: Stockholm
1977: Brussels
1986: Zurich
1995: Lisbon
1978: Vienna
1987: Berlin
1996: Bordeaux
1979: Madrid
1988: The Hague
1997: Brussels
1980: Geneva
1989: Paris
1981: London
1990: Brussels
1998: Dresden
1982: Philadelphia
1991: London
1999: Rome
2000: Zurich

In 1988, we inaugurated the "Geneva Lectures" series: Members of the Geneva Association and Chief Executive Officers are given the opportunity to present, through this initiative, their point of view on the key issues on the future of insurance in a country other than their own. In the Geneva Papers No. 51 we published the text of the first Geneva Lecture given in Zurich by Prof. Dr. Reimer Schmidt; in The Geneva Papers No. 57 are published the "Geneva Lectures" given by three of our members (Mr. Bebear, Mr. Randone, and Prof. Farny) in New York, Brussels and Madrid.

In addition, in order to identify and review the major strategic issues and planning procedures in the insurance industry, as well as to stimulate the discussion on Strategic Issues and Planning in Insurance, the Geneva Association has also organized, since 1982, in London a tri-annual conference. The proceedings of these meetings are published in the "Etudes \& Dossiers" series and partly in "The Geneva Papers". The following table summarizes the issues discussed at these conferences to which have participated between 80- 100 people from industry, insurance intermediaries and researchers from all over Europe, the United States, and sometimes from other continents. 


\section{THE GENEVA LECTURES}

October 1988 / Zurich:

June 1989 / NewYork:

February 1990 / Brussels:

May 1990 / Madrid:

November 1990 / Utrecht:

June 1991 / Londo11:

October 1991 / Athens:

March 1992 / Brussels:

September 1992 / London:

October 1992 / Vienna:

May 1993 / Lisbon:
First Lecture presented by Prof. Dr. Jur. Dr.-Ing. E.h. Reimer Schmidt, President of the Geneva Association, on "Collsequences of the Freedom of Services on Insurance in the European Community".

Second lecture presented by Mr. Claude Bebear, President of AXA Assurances on "The AXA Group Strategy". This session was chaired by Mr. John Roberts and organized by Prof. Denis Kessler.

Third Lecture presented by Mr. Enrico Randone, President of the Assicurazioni Generali, on "The International Strategy of European Insurance Companies". Chairmanship: Mr. Valere Croes, Mr. Michel Dewaersegger and Mr. Pierre Garny.

Fourth Lecture presented by Prof. Dr. Dieter Farny on "Corporate Strategy of European Insurers" with the participation of Mr. Felix Mansilla. This lecture was organized in collaboration with the Munich Re.

Fifth Lecture presented by Prof. Dr. Reimer Schmidt on "German Reunification and Insurance". This lecture was introduced by Mr. Bartelds, and was organized in collaboration with Munich Re.

Sixth Lecture presented on the occasion of the 18th General Assembly of the Geneva Association by Mr. Maurice Greenberg, President of the American International Group, New York, on "The Key Problems and Perspectives of World Insurance Today".

Seventh Lecture presented by Mr. Ruy de Carvalho, President of the Associaçao Portuguesa de Seguradores, on "The Portuguese Insurance Market's Experience Within the European Community and its Prospects for 1992 and Beyond". This initiative was also organized in collaboration with Munich $\mathrm{Re}$.

Eighth Lecture presented by Mr. Michel Albert, President of A.G.F., on "Insurance Distribution Networks in Europe Current and Future Trends". With the collaboration of three Belgian members, Mr. Valere Croes, Mr. Michel Dewaersegger, Mr. J.-P. Gerard, and was organized in collaboration with U.P.E.A. (Union Professionnelle des Entreprises d'Assurances).

Ninth Lecture presented on at the occasion of the 18th Seminar of the European Group of Risk and Insurance Economists by Mr. J.F.M. Peters, Chaiman Executive Board of AEGON N.V., on "Patterns of Internationalization for Insurance". Mr. Wolrath and Mr. Nelson Robertson have also contributed to this lecture.

Tenth Lecture, presented by Mr. Hans-Dieter Sellschopp, Member of the Board of the Munchener Ruckversicherung, on "Topical Issues Concerning Environment Liability and its Insurance".

Eleventh Lecture presented by Dr. Dieter Gobel, Member of the Board of the Münchener Rückversicherung, on "Worldwide Reinsurance - Possibilities, Risks and Perspectives". 
September 1993 / Rotterdam: Twelfth Lecture, presented by Drs. Jan Holsboer, Member of the Executive Committee, ING (lnternationale Nederlanden Groep), on "Specialization versus Diversification".

November 1994 / New York: Thirteenth Lecture presented by Dr. E. Coppola Di Canzano, Presidente e Amministratore Delegato, Assicurazioni Generali, Trieste on "Some Strategic Issues for Insurance Today".

March 1995 /London: $\quad$ Fourteenth Lecture presented by Mr. Hans Bartelds, Chairman of the Executive Board, FORTIS on "Transnational Mergers and Transnational Experiences in Insurance".

October 1997 / London: $\quad$ Fifteenth Lecture presented by Mr. Ronald Compton, C.E.O., AETNA Life Insurance Company and Dr. Neil Schlackmann, Senior Medical Director, AETNA US Healthcare, on "Health Management Organisations in the United States".

May 1998/Geneva:

Sixteenth Lecture presented by Mr. Michel Albert, Monetary Policy Council, Banque de France on "L'EURO et l'Assurance" and Mr. Walter Kielholz, Managing Director, Swiss Re on "The Future of Insurance in the World Economy".

\section{STRATEGIC ISSUES AND PLANNING IN INSURANCE.}

\section{THE TRI-ANNUAL CONFERENCE IN LONDON}

1982: First Conference. Proceedings published in the "Etudes \& Dossiers" from No. 59 to No. 65 .

The following issues were discussed:

- Strategic management and organizational design in insurance companies.

- Planning experiences at the company's level.

- Planning for insurance development at the country level.

- An enquiry on the level and developments of strategic planning within 40 insurance companies in Europe.

- Models for insurance planning.

- Specific subjects for defining planning objectives: Appropriate level of capital, controlling fair profits and measuring the distribution of total annual claims.

- Comparing planning experiences: Planning in industry, banks and brokers and planning in the Australian insurance.

1985: Second Conference. Proceedings published in the "Etudes \& Dossiers" No. $100 \&$ No. 101.

The following issues were discussed:

- The economic environment and the strategy for insurance.

- Strategic approach to insurability of risks.

- Getting started in strategic planning for insurance.

- Experiences and specific examples within insurance companies in strategic planning.

- The limits of insurability. 
1988: Third Conference. Proceedings published in the "Etudes \& Dossiers" No. 132 \& No. 133.

The following issues were discussed:

- Insurers' strategy planning.

- Issues for Europe 1992: The role of ECU and harmonizing taxes.

- Planning issues for insurance: Genetic risks, the Four Pillars, environmental liability.

1991: Fourth Conference. Proceedings published in the "Etudes \& Dossiers" from No. 166 to No. 169.

The following issues were discussed:

- Insurance in national economies.

- The Four Pillars.

- The private utilization of ECU for insurance.

- Present developments and future perspectives of telecommunication networks in insurance at the national and international levels.

- Planning strategies of insurance companies: comparisons with the study done in 1982.

- Comparative study in personal liability.

1994: Fifth Conference. Proceedings published in the "Etudes \& Dossiers" No. 193 The following issues were discussed:

- Insurability in property and casualty insurance and reinsurance.

- Insurability in life insurance and the future of social policies.

- Insurability facing the problems of crime and terrorism.

- Major concerns in the future of social policy - the aging of the Population - the research issues of the Geneva Association on "The Four Pillars".

- Toward a new management of end-of-year career.

- Bio- and Gene-Technology - risks and vulnerabilities: challenges for insurance.

- The role of derivatives in insurance (the risk management of total portfolio and - the effects on solvency, portfolio enhancement, the security issue.

1997: Sixth Conference. Proceedings published in the "Etudes \& Dossiers" No. 217 $\& 218$.

The following issues were discussed:

- Capital aspects of modern insurance.

- Latest update on introduction of Euro: Political, Economic and technological issues.

- World trade organisation: insurance + financial services in WTO.

- Managing health care + insurance: cost control issues and the health industry.

- Insurance industry perspectives.

- The Four Pillars: promoting gradual retirement and financing future pensions.

- Current issues on risk management (joint session with, IRM - Institute of Risk Management) / vulnerabilities - today the individual, tomorrow the world. 


\section{PROGRES SEMINARS}

\section{(Program of Research of Economics and Services)}

The first six seminars were held annually from 1985 to 1990 at the University of Geneva on the notion of the service economy.

May 1991

Paris:

September 1992

Geneva:

September 1993

Geneva:

September 1994

Prague:

August 1995

Geneva:

August 1996

Geneva:

September 1997

Geneva:

September 1998

Geneva: 7th Seminar on the service economy. Specific issues included: world trade in services: examination of the results of the Uruguay Round Negotiations, services as Instruments of economic eastern European countries, employment and social policy in services in Western european countries, productivity, fiscality and investment in the service economy.

8th Seminar. Specific issues included: services as instruments of economic developments in eastern Europe, employment and social policy in the service economy, productivity, fiscality and investment in the service economy.

9th Seminar in collaboration with ASEC (Applied Service Economics Centre). Specific issues included: services in the eastern European countries, the Four Pillars, national case studies, up-date on the GATT negotiations.

10th Seminar in collaboration with RWI (RheinischWestfälisches Institut für Wirtschaftsforschung) and the Research Institute of the Czech Ministry of Economic Affairs Prague. Specific issues included: services and economic development in eastern Europe, issues in world services, insurance services in eastern Europe, entry into force of the WTO and GATS, accounts of insurance undertakings in a single european insurance market.

11th Seminar. Specific issues included: employment and retirement in the service economy, employment. Services: the experience of emerging countries in Europe, employment, unemployment and services, gradual retirement in the OECD countries, new management policies on end of career in Switzerland.

12th Seminar in collaboration with Julian Arkell, ITSP International Trade and Services Policy. Specific issues included: catastrophic risks - dealing with the future, services and the trade liberalization - agenda of the WTO (World Trade Organization).

13th Seminar in collaboration with Julian Arkell, IRSP. Specific issues included: the liberalization of financial services.

14th Seminar organized in collaboration with Julian Arkell, ITSP. Specific issues treated: services developments and preparations for the services negotiations in 2000 liberalization negotiations, sector issues, the impact of other relevant agreements, and general services issues. 


\subsection{The WIN- the world insurance program ${ }^{15}$.}

Insurance is an integral part of the world global service economy. The Association's research program in this area has embraced various initiatives and studies aimed inter alia at evaluating:

- The obstacles to international trade in insurance, as well as its effects on the balance of payments $;^{16}$

- The future of export credit insurance: due consideration being given to the complementary role of the State and banks $;^{17}$

- The problem of coping with natural disasters at the world level, in collaboration with international bodies such as UNDRO (the United Nation Disaster Relief Organization, which coordinates national and international actions in this field) and UNESCO (in particular its research division) $;^{18}$

- We have also collaborated with the World Meteorological Organization (WMO) for a seminar on "climatic change"; 19

- The question of the development of international telecommunication networks for insurance has been dealt on various occasions, through studies and seminars, with the contribution of European and American experts, as well as of insurance telecommunication networks (RINET, ASSURNET, RITA, etc.);

- The international evaluation of fire costs, through the World Fire Statistics Center; this was the outcome of a statistical study initiated twenty years ago and which resulted in our annual collaboration with the United Nations organizations in Geneva, in collecting fire statistics.

Following the awarding of a scholarship seventeen years ago on the subject of the economic implications of European integration and insurance, this work led to a report of over 700 pages, on "Private Insurance in the European Communities" which also provides details about the agreement between the European Common Market and Switzerland. ${ }^{20}$

The process of the European economic integration has also been the reference for two important lines of research:

- The question of the private utilization of the ECU (European Currency Unit), and insurance. Specific studies have been published on this issue in the "Etudes \& Dossiers" and in "The Geneva Papers"21.

${ }^{15}$ See in particular The Geneva Papers, Nr. 63, April 1992, which describes insurance in connec tion with the activities of eight international institutions.

${ }^{16}$ The first study on this issue was published in Etudes \& Dossiers, Nr. 9, November 1976.

${ }^{17}$ The key report on this issue was written by Henri Loubergé and Pierre Maurer, "Financement et assurance des credits a l'exportation", and published by Librairie Droz, Geneve, 1985, 502 pp., the English version of this study was published in Etudes \& Dossiers, Nr. 85, December 1984, and Nr. 86, January 1985. 1984.

${ }_{18}$ See the "Natural Disasters and Insurance", The Geneva Papers, Nr. 30, Nr. 31, and Nr. 32,

${ }^{19}$ See "Climatic Change", The Geneva Papers, Nr. 64, July 1992.

${ }^{20}$ See Etudes \& Dossiers, Nr. 149 - 152, from November 1990 to Eebruary 1991.

${ }^{21}$ See Etudes \& Dossiers, Nr. 136 - July 1989, Nr. 140 - November 1989, Nr. 167 - May 1992, The Geneva Papers Nr. 57, October 1990. 

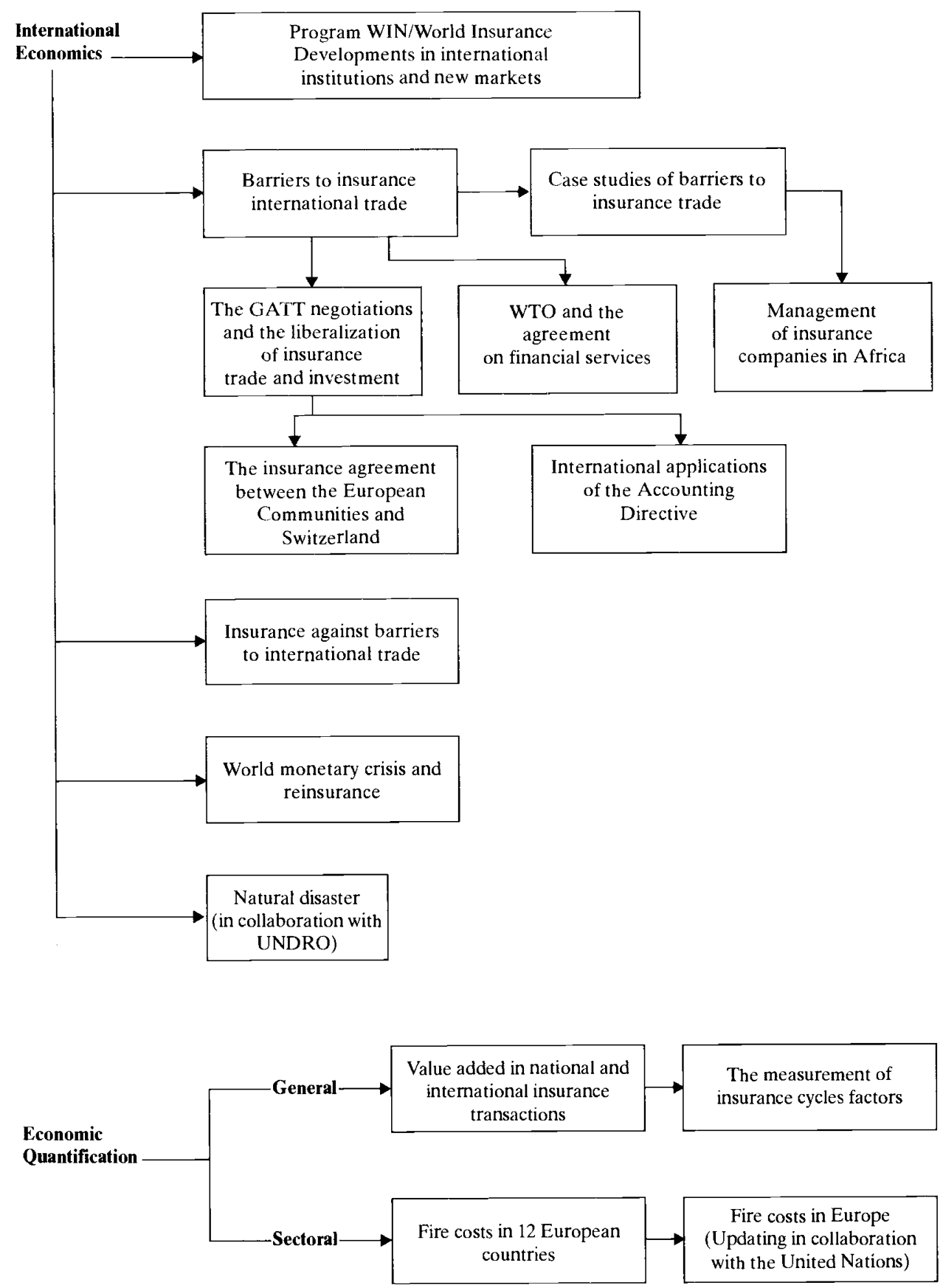


\section{The World Fire Statistics Center and International Seminars}

That fires cost around 1\% of Gross Domestic Product in many European countries is the simple but urgent message the World Fire Statistics Center is trying to get across to governments and to society. The Center, established under the auspices of the Geneva Association, is the result of the pioneering work of Mr. Tom Wilmot, who through the Center for Contemporary European Studies at the University of Sussex, studied fire costs in a number of European countries.

The Center, which operates from the Association's offices, is working closely with the United Nations on a scheme under which 13 leading countries including the US and Japan are producing, for the first time, national statistics covering both fire losses and the costs of fire protection.

The Center believes that it has identified several major gaps in the level of international cooperation over fire prevention by persuading governments to produce national fire costs figures. Two gaps are being plugged: the lack of statistics means national fire strategy is speculative and the lack of top level political interest in cutting fire costs.

Every three years the Center has organized a Seminar to which a small number of international fire experts are invited. The Fifth Seminar in May 1997 attracted 40 experts from USA, Australia, and the leading European countries. Organized jointly with the European Arson Prevention Institute (EAPI), the theme was "The Need for European Statistics for Arson and for Large Fires". EAPI joined with the Geneva Association in the Seminar organization as they felt that reliable arson statistics are crucial for the monitoring of national and international campaigns against arson.

EAPI also joined the Center in an approach being made to the EEC asking them to tackle fire costs on an international basis, bearing in mind the success of international campaigns to reduce road accidents.

Insurers have much to gain from greater international cooperation in reducing fire losses - thus carrying on a tradition started long ago by the formation of fire protection associations by farsighted insurers.

- The question of the interpretation and of the national application possibilities of the Accounting Directives in the European Community has also been the subject of a series of research seminars organized by the Geneva Association under the leadership of Dr. Hans-Joachim Welzel, Vice-Secretary General, and with the collaboration of KPMG. Dr. Welzel had introduced this subject for the first time in "The Geneva Papers" Nr. 49 (July 1988). He then prepared a detailed dossier on the "European Account Directives" which has been distributed in "Etudes \& Dossiers" Nr. 173 (February 1992). Since 1992, a series of seminars have been organized with selected experts in insurance companies in Italy (Milan, October 1992), in Portugal (Lisbon, December 1992), in Greece (Athens, April 1993). The fourth presentation has been organized in Vienna, on June 8, 1995, the fifth one took place in Madrid, in June 1996 and the sixth was in Budapest, Hungary in 1997. 


\section{Seminars on the Private Utilization of ECU and Insurance}

March 1989/Geneva: $\quad$ First Seminar on "The Impact of the European Monetary System" and on "The Private Utilization of ECU's on Insurance".

May 1989/Geneva: Second Seminar held at the Graduate Institute of European Studies on "Switzerland and the European Monetary System".

November 1989 / London: Third Seminar on "The Private Utilization of ECU", organized at Lloyd's with the collaboration of the City University Business School.

October 1991/London: Fourth Seminar on "The Private Utilization of ECU and insurance: European Monetary Integration, the ECU and the Insurance Industry in the 1990s", at the 4th International Strategic Issues and Planning in Insurance Conference at Eagle Star offices, in collaboration with DYP / IRRG Group, London.

June 1995/Lisbon: Fifth Seminar on "The Future Perspectives of the European Monetary System: Implications for Insurers" held at the 22nd General Assembly of the Geneva Association.

June 1997 / Brussels: Sixth Seminar on "The Effects of the Utilization of EURO on Insurance", held at the 24th General Assembly of the Geneva Association.

October 1997 / London: Seventh Seminar on "The Latest Update on Introduction of EURO - The Impact of EMU on the Financial Sector". Seminar at the conference on Strategic Issues in insurance at Plaisterers Hall in London and organized in collaboration with Jim Bannister Developments.

\subsubsection{The liberalization of trade in services}

The Gatt (now WTO - World Trade Organisation) negotiations and their impact on international trade in services have deserved special attention. As a consequence of our research activity on the service economy since 1985, the Geneva Association has contributed, for the last four years, to an informal association of experts in different service sectors, called ASEC (Applied Service Economics Center, Geneva).

The major sectors represented in this organization are: telecommunications, professional services, banking and transportation. This Center also collaborates with several "coalitions" in the service sector from various countries (United States, Great Britain, etc...).

From 1990-92, ASEC organized annual seminars to bring together GATT experts, negotiators on services and representatives of service industries or groups. 
At each of the three seminars, the Geneva Association ensured that an adequate showing and contribution were made by the insurance sector. Professor Raymond Barre, first President of the Geneva Association, opened and presented his comments to the first of these seminars. Sir Brian Corby, as President of the Geneva Association and of the Confederation of British Industries, delivered the inaugural address at the second seminar. Further contributions to these seminars included: Professor Denis Kessler, President of the French Federation of Insurance Companies; Mr. Francis Loheac, Secretary General of the Comité Europeen des Assurances; Mr. Ruy de Carvalho, President of the Portuguese Federation of Insurance Companies; and Mr. Oakley Johnson, Vice President of American International Group 22 .

After 3 years, the ASEC initiative was integrated with the PROGRES program launched by the Geneva Association to stimulate studies on the service economy.

There is every likelihood that services will become increasingly important for the future activities of the World Trade Organization (WTO) and of any similar organization: in the course of the next decade, negotiations on services trade and on the conditions of establishment and investment will become critical at a world level.

More recently, our studies on the service economy and risk management have reached across Asia, where many countries, including China, Malaysia and Singapore, have on a number of occasions invited the Geneva Association to speak on these issues. This development also concerns Japan with whom for many years now we have collaborated in connection with the Four Pillars research program.

$$
* * *
$$

Finally, many of our studies and collaborative ventures have involved the United States but these initiatives are mentioned in other chapters of this report (issues concerning the Fourth Pillar, the comparison of liability procedures, risk management studies, various lectures and editorial work for The Geneva Papers on Risk and InsuranceTheory, mentioned later on). We should however mention here that for many years, the Geneva Association has collaborated with the Wharton School of the University of Pennsylvania on the studies done by the Center of Risk Decision. In this latter connection, hazardous waste management problems were discussed and representatives of insurance companies, chemical industries and government officials from the United States and European countries, contributed. The Geneva Papers Nr. 51 on "Hazardous Waste Management" are one of the products of this collaborative venture. In it the problems of liability and the reorganization of the EPA (Environmental Protection Agency) are carefully examined. Further details on activities in all these can be found in our Newsletters.

22 See the Proceedings of the First and the Second Geneva International Forum on Global Services and Trade Liberalization, "Uruguay Round Trade in Services Perspectives", ASEC,1990,128 pp., and "The Uruguay Round and Beyond: What Future for Services Trade Liberalization?", ASEC, 1991, 169 pp. See also "Insurance and Services in International Trade", The Geneva Papers, Nr.61, October 1991. 


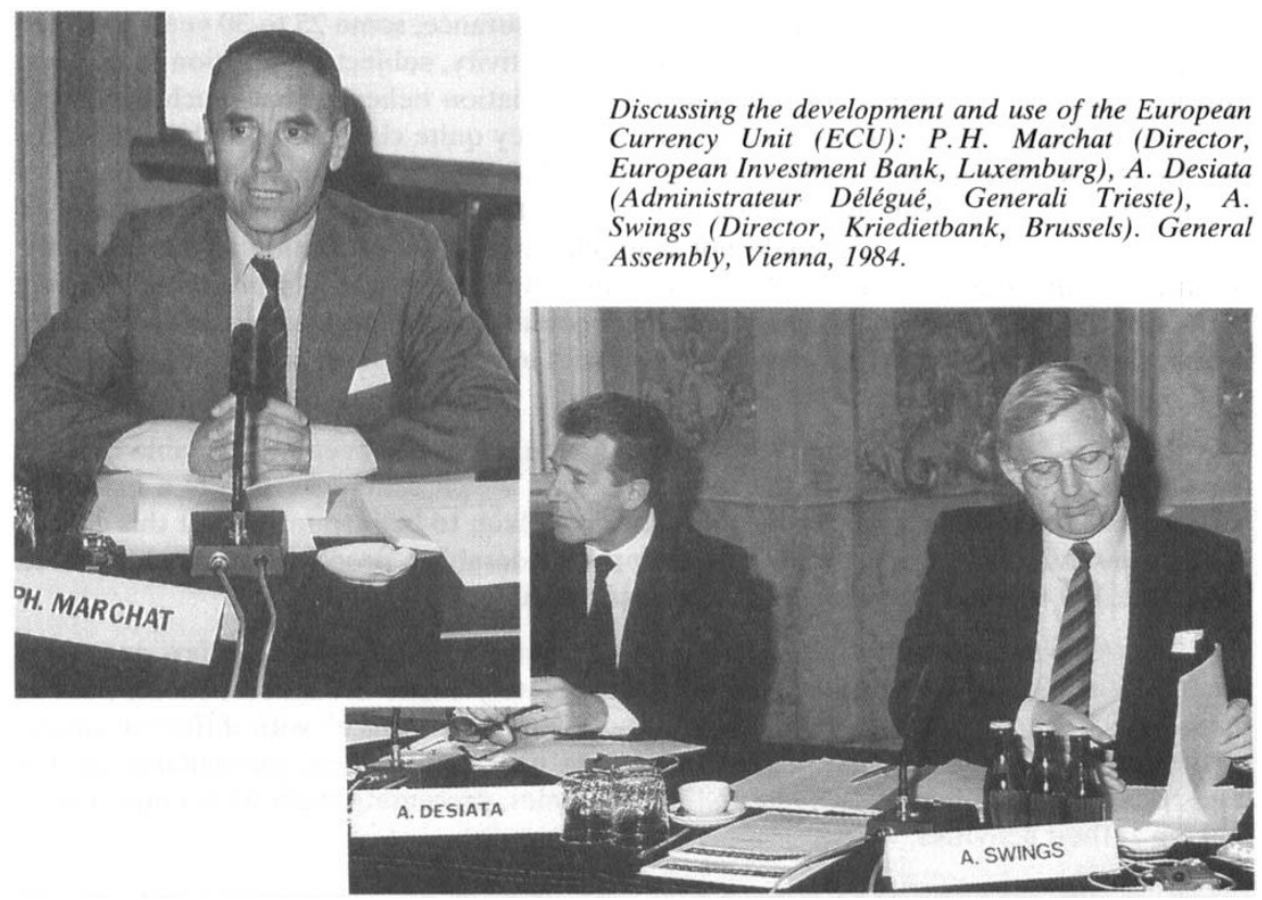

\section{Developing Insurance Economics}

\subsection{The economic function of insurance}

The stated aims of those founding the Association to make an original contribution to the progress of insurance through objective studies of the interdependence between economics and insurance, contains nothing too alarming. But the Association's founders had real intentions for their new body. What in fact they wished to achieve was nothing less than a fundamental change in the way insurance is perceived in society and for good measure within the insurance industry itself. Not, it must be emphasized, in a superficial public relations image building way, but in the more fundamental sense, by altering the perception of the intellectual and social significance of insurance.

From this point of view, until the 1970s the industry has been left in a virtual back water. For the most part, it had been ignored by those who at the least might have been expected to show interest - the economists. Whatever this might mean in terms of the industry's psychological self-esteem, there were very serious implications in practical terms. For if the industry wished to influence those who advised the decision-makers at national or international level, it did not have much prospect if these advisers had not the slightest idea of the industry's contributions to the economy.

This lack of interest by outsiders and in particular by economists can only have had an adverse effect on those within the industry by not providing a stimulus for insurance people to examine systematically the economic functions of the activity they were engaged in. 
Is it not a too crude generalization to say that insurance, some 25 to 30 years ago, was in the eyes of most economists a peripheral social activity, subject to question marks and raised eyebrows: The founders of the Geneva Association believed that much needed to be done to change this dangerous state of affairs. They quite clearly stressed the need for the industry to plug itself into modern intellectual life, and in particular into the ambit of economics and its practitioners. They saw clearly that the industry had little hope of influencing policy-makers, if it could not point clearly to its contribution to the economy. In turn, this affected the chances of recruiting the brightest people into insurance. Indeed, until recently, most of those passing through economics courses in universities and colleges in Europe at best would have looked at the subject in only the most cursory of ways, with the exception of one country.

Since the foundation of the Geneva Association, there has been a noticeable quicken ing of interest by economists in the insurance area, which cannot be purely a matter of coincidence. Even though the Association does not claim to be responsible for this change in attitude - its activities must have speeded up considerably a process that may have been inevitable, but still could have moved only imperceptibly.

The Association could have decided to concentrate its efforts into a few areas and produce some showpiece results. Instead it deliberately chose the more difficult path of spreading itself in a number of directions to broaden its "interface" with different aspects of the economy. In doing this it has opened up new perspectives, particularly for the industries where it carries out its research programmes, presenting them with a new way of looking at their activities.

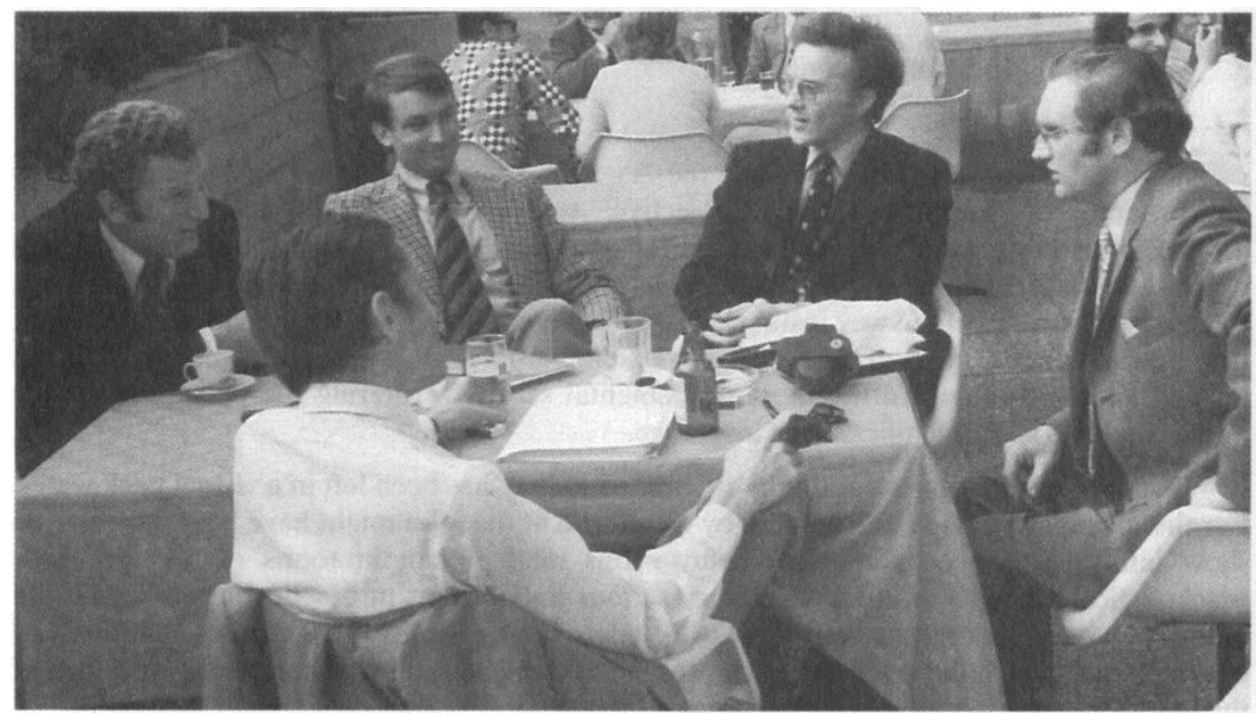

The second Annual Meeting of the European Group of Risk and Insurance Economists in Geneva (1974). From the left: Prof. D. Farny (University of Cologne), Prof. E. Helten (University of Mannheim), Prof. Gerry Dickinson (City University Business School, London), Prof. R. Carter (University of Nottingham). In the foreground: Prof. S. Lambert (University of Lyon). 
In this work and in the relations with universities, the Association finds it no longer has to strive as it once had to gain the attention and understanding of academics and professional researchers. It has established itself as part of the scene and some measure of this is that to a greater and greater extent, instead of the Association seeking out, it finds that it is being sought out.

\subsection{The university program on risk, insurance and the economics of uncertainty}

The first problem which confronts insurance with regard to economics is that general economic theory, as it is still taught today, does not give students of economics an adequate idea of the economic function and importance of insurance and risk management.

This situation in economic theory has had the drawback for insurance of it being often misunderstood and, moreover, probably reduced the ability of contemporary economic theory itself, to interpret correctly the development of modern economies.

The first strategic point of attack in order to establish credibility for insurance economics at the highest academic level has been the organization, since 1977, of Geneva Lectures. The first lecture was given by the Nobel Prize winner, Kenneth Arrow, and since then, some of the best known economists in the world have contributed to this initiative (see box next page).

This initiative has been essential to create the scientific credibility and excellence of the Geneva Association in the field of economic theory. This achievement has been confirmed and consolidated in 1990 by the creation of the "The Geneva Papers on Risk and Insurance - Theory": Since 1991 this bi-annual review has been published by Kluwer Academic Publishers (Boston, Dordrecht and London) which is really well-reputed in academic circles. The editorial work for this publication was taken over at the beginning by Prof. Henri Loubergé, a former Vice-Secretary General of the Geneva Association and professor at the University of Geneva, as well as by Prof. Harris Schlesinger, professor at the University of Alabama who as just been elected President of the American Risk and Insurance Association. The editorial responsibility for the Geneva Papers - Theory has now been taken over by Professor Christian Gollier of the University of Toulouse and by Professor Neil Doherty of the Wharton School, University of Pennsylvania. It must be noted that the associate editors of this publication include some of the best known economists in the world, from prestigious universities such as Harvard, Stanford, HEC Paris, and many others. It is the first time in the history of insurance that a solid link has been developed at such a level: this is of fundamental importance in order to provide a signal for all universities of economics in the world that the teaching of insurance is now "acceptable".

The strategy of the "Annual Lectures", has been backed and extended by several initiatives promoting the academic development of risk and insurance economics such as:

- The organization since 1973 of an annual seminar for The European Group of Risk and Insurance Economists, in order to stimulate research and teaching in areas linked to economics and insurance. This is with the collaboration of university professors and lecturers who are already involved in these areas because of their own fields of activity. Participation at these seminars which now attracts many candidates is, of course, limited and has necessitated in recent years severe selection of participants as well as of papers submitted. 


\section{The Geneva Association Annual Lectures}

Each year, since 1977, an Annual Lecture has been given by an economist of repute, dealing with a subject of theoretical importance on the problems of risk and insurance. The Annual Lectures of the Geneva Association have dealt with the following topics:

1977: "Risk Allocation and Information: Some Recent Theoretical Developments", by Kenneth J. Arrow, Nobel Prize winner for Economic Science (Stanford University). Lecture given at the London School of Economics.

1978: "Human Capital and Risk-Bearing", by Jacques Dreze (Louvain University). Lecture given at the "Institut d'Etudes Politiques", Paris.

1979: "The Effects of Social Security on Savings", by Martin Feldstein (Harvard University). Lecture given at the "Institut d'Etudes Politiques", Paris.

1980: "The Three Markets for Private Insurance", by Karl Borch (Bergen University). Lecture given at the "Universite Libre de Bruxelles".

1981: "Risk Incentives and Insurance: the Pure Theory of Moral Hazard", by Joseph Stiglitz (Princeton University). Lecture given at the "Eidgenossische Technische Hochschule", Zurich.

1982: "Facing Risks in Changing Economies and Societies", by Raymond Barre. Lecture given at the Wharton School, University of Pennsylvania.

1983: "Reflections on Uncertainty", by Walter A. Weisskopf (Professor Emeritus of Economics, Roosevelt University of Chicago). Lecture given at the International Center for Theoretical Physics, Miramare - Trieste.

1984: "The Economics of Unemployment Insurance", by Edmond Malinvaud (Institut National de la Statistique et des Etudes Economiques, Paris). Lecture given at the University of Oslo.

1985: "Risky Choices in Medical Decision Making: A Survey", by Milton C. Weinstein (Harvard School of Public Health, Boston). Lecture given at the University of Mons, Brussels.

1986: "International Trade in Services and Its Relevance for Economic Development", by Jagdish N. Bhagwati (Columbia University). Lecture given at the Graduate Institute for International Studies, Geneva.

1987: "Uncertainty in Macroeconomics", by George von Furstenberg (Indiana University). Lecture given at the University of Cologne.

1988: "The Application of the Continuous-Time Theory of Finance to Financial Intermediation and Insurance", by Robert C. Merton, J.C. Penney, and Alfred P. Sloan (Massachusetts Institute of Technology, Cambridge). Lecture given at the Center HEC-ISA, Paris.

1989: "Risk in Science and Society", by Ilya Prigogine, Nobel Prize winner (International Institute of Physicals and Chemicals, Brussels). Lecture given at Hotel Intercontinental, Paris. 
1990: "Competition, Productivity and Efficiency in the Insurance Market", by William Baumol (New York University). Lecture given at the SAS Royal Hotel, Brussels.

1991: "Social Insurance", by Tony Atkinson (London School of Economics). Lecture given at the William Kent House (Eagle Star), London.

1992: "Experiences and Perspectives of Financial Services in Eastern Europe", by John S. Flemming (European Bank for Reconstruction and Development EBRD, London). Lecture given at the Palcio de Congresos, Madrid.

1993: "Uncertainty under the Welfare State", by Assar Lindbeck (Institute for International Economics, Stockholm University). Lecture given at the University of Stockholm.

1994: "Social Protection and Private Insurance.Reassessing the Role of Public Sector versus Private Sector in Insurance", by Pierre Pestieau. Lecture delivered at the University of Bordeaux.

1995: "Insurance and Catastrophes", by Richard Zeckhauser (J.F. Kennedy School of Government, Cambridge, USA). Lecture delivered at the F.E.S.A. in Paris.

1996: "The Economics of Intergenerational Transfers", by Denis Kessler (former President, FESA Paris). Lecture delivered at the London School of Economics.

1997: "Rethinking Society's Management of Catastrophic Risks", by Howard Kuntreuther, Wharton Risk Management Center, University of Pennsylvania. Lecture delivered at the University of Guildford, England.

1998: "The Stock Market as Risk Manager" by Peter L. Bernstein. Lecture delivered in Paris on October 1 at the C.N.A.M. (Centre National des Arts et Métiers).

The following professors of economics have also contributed as discussants to these lectures:

A. Alperovitch, A.B. Atkinson, M. Beenstock, A. Bjorklund, D. Bland, C. de Boissieu, W. Buiter, R.L. Carter, E.M. Claasen, H. Clemeur, M. Coppini, F. Corlier, D. Cummins, J.-M. Detry, M. Drummond, E. Franckx, D. Gale, C. Gollier, D. Hart, M. Hellwig, B. Hinley, D. Kessler, H. Kierzkowsky, J.-J. Laffont, H. Loubergé, J. Morishima, S. Nickell, V. Norman, M.J. Neumann, R. Passet, W. Perraudin, P. Pestiau, M. Pfaff, G. Priest, J.J. Rosa, S. Ross, J.-C. Sailly, A. Sandmo, A. Sapir, M. Scholes, G. Skogh, B. Skolnik, E. Steigum, D. Strauss-Kahn, P. Tschopp, J. Waelbroeck, R. Zeckhauser. 


\section{Conferences of the European Group of Risk and Insurance Economists}

Each year, since 1974, the European Group of Risk and insurance Economists holds a conference on the developments of research in risk and insurance management in Europe.

1974 - From the 1st to the 6th year, the Seminars of the European Group of Risk and Insurance were organized at the University of Geneva, Switzerland.

1980: 7th Seminar, University of Nottingham, U.K.

1981: 8th Seminar, University of Cologne, Germany.

1982: 9th Seminar, University of Geneva, Switzerland.

1983: 10th Seminar, University of Rome, Italy.

1984: 11th Seminar, University of Geneva, Switzerland.

1985: 12th Seminar, Institute Catholique des Hautes Etudes Commerciales (ICHEC) of Brussels, Belgium.

1986: 13th Seminar, University of Hamburg, Germany.

1987: 14th Seminar, Graduate Institute of European Studies at the University of Geneva, Switzerland.

1988: 15th Seminar, Universidad Nova of Lisbon, Portugal.

1989: 16th Seminar, Institut des Hautes Etudes Commerciales (HEC) of Paris, France.

1990: 17th Seminar, Institut fur Versicherungswirtschaft of the University of Vienna, Austria.

1991: 18th Seminar, Catholic Faculties of Mons, Belgium.

1992: 19th Seminar, City University Business School of London, England.

1993: 20th Seminar, Erasmus University, Rotterdam, The Netherlands.

1994: 21th Seminar, University of Toulouse.

1995: 22nd Seminar, University of Geneva, Switzerland.

1996: 23th Seminar, University of Hannover, Germany.

1997: 24th Seminar, University of Paris, France.

1998: 25th Seminar, Wirtschaftsuniversität, Vienna, Austria.

1999: 26th Seminar, University of Madrid, Spain.

2000: 27th Seminar, University of Rome, Italy.

Professors from all these universities have contributed to our seminars: Alabama, Alberta, Australian National, Bangor, Bar-llan, Bergen, Berlin (2 universities), Brussels, Budapest, California (3 universities), Coimbra, Cologne, Copenhagen (2 universities), Duke, Francfort, Geneva, Ghent, Glasgow (2 universities), Graz, Groningen, Haïfa, Hamburg, Hannover, Hebrew at Jerusalem, Illinois (2 universities), Lisbon, London (3 universities), Louvain, Lund, Lyon, Madrid, Mannheim, Michigan, Milan, Mons (2 universities), Moscow, Montreal (2 universities), Munich, Newcastle, Nottingham (3 universities), Ohio State, Oregon State, Orleans, Paris (4 universities), Pennsylvania (2 universities), Poznan Prague, Radom, Rome (3 universities), Rotterdam (2 universities), Rutgers, Stanford, St-Gallen, Stockholm, Tel-Aviv, Temple, Texas at Austin, Toulouse, Vanderbilt, Vienna, Wisconsin, York, Zurich. 


\section{The Geneva Risk Economics Lectures}

1989: 1st Conference organized in Paris, on the occasion of the 16th Seminar of the European Group of Risk and Insurance Economists. Conference on "Expected Utility and Non-Expected Utility with Special Application to Insurance" by Mark Machina of the University of California.

1990: 2nd Conference, organized in Vienna, on the occasion of the 17th Seminar of the European Group of Risk and Insurance Economists. Conference on "Versicherungswissenschaft - Zwischen Theoretischem Anspruch und Empirischer Relevanz" by Elmar Helten of the Ludwig-MaximiliansUniversitat, Munich.

1991: 3rd Conference, organized in Mons (Belgium), on the occasion of the 18th Seminar of the European Group of Risk and Insurance Economists. Conferences given by Steve Diacon of the University of Nottingham on "Insurance and Managerial Quality", and by Yaffa Machnes of the Bar-Ilan University (Israel) on "Further Results on Comparative Statics Under Uncertainty"

1992: 4th Conference, organized in London, on the occasion of the 19th Seminar of the European Group of Risk and Insurance Economists. Conference on "Aspects of Insurance and Intermediation" by Michael J. Brennan of the University of California at Los Angeles.

1993: 5th lecture held at the 20th Seminar for the European Group of Insurance Economists in Rotterdam. (Van den Berghe - De Witt)

1994: 6th lecture on "Government Interventions, Biased Perceptions and Insurance Related Behaviour", by W.K. Viscusi, Duke University, Durham, North Carolina. Held at the 21st Seminar of the European Group of Risk and Insurance Economists, in Toulouse.

1995: 7th lecture on "The Term Structure of Interest Rates: Alternative Paradigms and Implicatious for Financial Risk Management", by Marti Subrahmanyam. Held at the 22nd Seminar of the European Group of Risk and Insurance Economists in Geneva.

1996: 8th lecture on "Competition in Insurance Markets: 20 years later" by Michael Rothschild, Princeton University. Held at the 23rd Seminar of the European Group of Risk and Insurance Economists, in Hanover.

1997: 9th lecture on "Econometrics of Insurance" by Mr. Christian Gouricroux. Held at the 24th Seminar of the European of Risk and Insurance Economists in Paris.

1998: Special Geneva Risk Economics Lecture given by Professor Dieter Farny, Director, Institut für Versicherungswissenschaft an der Universität zu Köln, Honorary Member of the Geneva Association, on "Theorie und Praxis der Versicherungswirtschaft im Lichte der Entwicklungen in den letzten 25 Jahren" organized on the occasion of the 25th anniversary of the Geneva Association as well as for the 25th seminar of the European Group of Insurance Economists in Vienna on September 22, 1998. This special lecture is organized with the participation of a large number of representatives from the insurance business community and the academic community of Vienna. 
- Within the European Group of Risk and Insurance Economists, the Geneva Association has also organized "The Geneva Risk Economics Lectures" since 1989.

- The publication of The Geneva Papers on Risk and Insurance - Issues and Practice. The first issue of this quarterly journal goes back to January 1976. In July 1998, the issue Nr. 88 will be published. We have now established a tradition which is 22 years old. This journal is normally distributed, for each issue, to 2'200 people around the world. Starting in 1998, it is also diffused on Internet and as of 1999 its distribution will be extended through the collaboration of an important international publishing company.

- The publications of a Newsletter, published twice a year, which keeps economists up to date on the activities of the Geneva Association on questions concerning risk and insurance research, publications and teaching. This Newsletter is now distributed to 3'400 economists, institutions and experts in the world.

- Since 1976, the Geneva Association has published the results of a study on the Teaching of Risk and Insurance Economics in European Universitites. The original version was written in French. In 1978, it was brought up to date and edited in German; in 1981 in English. In 1987 again in French. In 1992, we have published a "First Survey of Teaching and Research Insurance in Eastern Europe". Finally, a databank has been developed at the City University Business School, in London, on the teaching of risk and insurance economics with the help of the Geneva Association and which is cons tantly updated. The summary of the courses available in this databank has been published in the "Etudes \& Dossiers" No. 177 of the Geneva Association.

\section{Economic Theory and Insurance Economic Teaching}

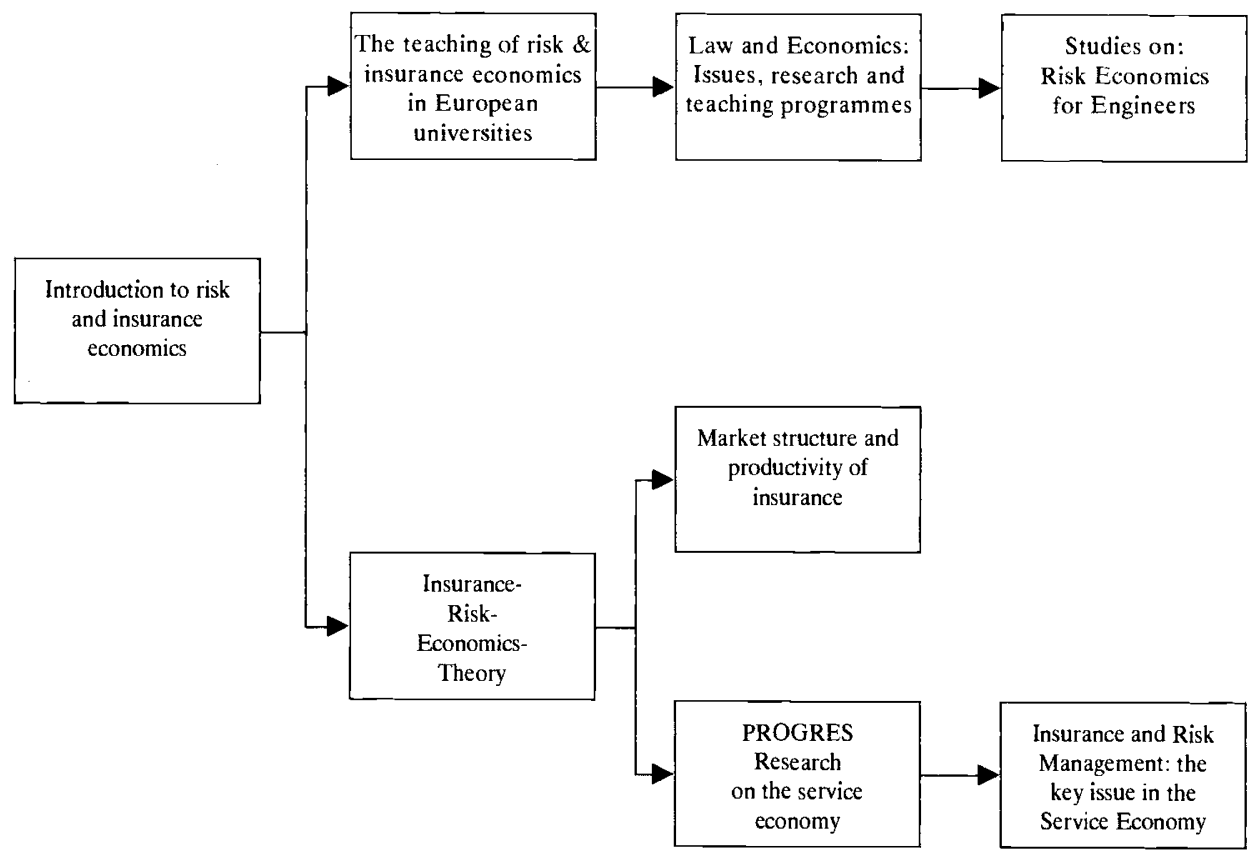


- In 1982, an extension of this type of research into the Teaching of Economics of Risk and Insurance to Engineers in European Universities was started in England, Holland, and in the Scandinavian countries. The report was published in 1984. A similar enquiry was published in November 1988 for Germany (Risk Management und Versicherungslehre). In 1993, we have also published a similar enquiry conducted by an Italian insurance research organization, CINEAS, linked to the Polytechnic University of Milan, on the Italian situation in this area.

- The Geneva Association has also promoted the cross-fertilization between Law and Economics in Insurance. We have developed since 1985 a close collaboration with the European Association for Law and Economics, which has about 250 members spread in universities and research centers in several European countries. Seven joint seminars have been organized since then, and in addition, a representative of the Law and Economics Association is organizing their contribution to the Geneva Papers since issue Nr. 58 / January 1991.

\section{Bi-annual Seminars on Law and Economics}

1985: Geneva $\quad$ First joint Seminar with the EALE (European Association of Law and Economics) on "Liability, Insurance and Regulation".

1988: Geneva Second joint Seminar on "Professional Liability".

1989: Lund (Sweden) Third joint Seminar on "Insurance and Transaction Costs".

1991: Paris $\quad$ Fourth joint Seminar on "Law and Economics of Environmental Policy".

1993: Geneva $\quad$ Fifth joint Seminar on "The Law and Economics of Insurance and of Services".

1995: Yvoire (France) 6th joint Seminar on "Law and Economics of Industrial Risks, Waste Treatment, and Environmental Accidents”.

1997: Hamburg 7th joint Seminar on "Law and Economics of Insurance".

1999: Utrecht (NL) 8th joint Seminar on "The Law and Economics of Insurance".

- The Geneva Association has been also collaborating with the Italian Foundation CESAR for promoting the first gathering of all research centers in the field of insurance which took place in Venice in 1991. Sixteen research centers participated at this first meeting which is planned to be organized every two years under the name of "The Venice Insurance Research Conference". The second one has taken place in October 1993. The third in April 1996. 
The first of these conferences was on "Research Programs and Activities of the European Insurance Study and Research Centers; Communication Technologies for Insurance and their Development on National and International Levels". The second concentrated on "The Economic Role of Insurance". The third discussed "Ethics, it's Economic Role and it's Importance for the Insurance and Risk Management Industry; Monetary Stability and Liberalization of Services". The fourth conference, also organized with CESAR, will take place in Venice in April 2000.

- Since the foundation of the Geneva Association, one or two grants per year have been provided to students preparing theses on the theory or risk and insurance; the "Ernst Meyer Prize" is also awarded, in recognition of a higher degree thesis on risk and insurance; a grant is also awarded every year to enable the publication of a deserving thesis. All this has contributed to the publication of about fifteen books, some with first class editors.

- In addition, when an economic theme of importance needs examining, the Geneva Association organizes ad hoc seminars, the largest was on "The Economic Value of Life and Safety". This seminar, held in Geneva in 1981, gathered some of the most reputed economists dealing with this subject and their contributions where published in 1982 by North Holland. We have also published another study made by Prof. E. S. Kirschen in the "Etudes \& Dossiers" Nr. 70, July 1983, entitled: "La valeur d'une vie humaine".

- During the 1980s, the Geneva Association also conducted some tests in order to develop methods of teaching risk and insurance economics using video tapes. One of these tapes was produced by the Open University of the U.K., concerning the notion of risk and uncertainty linked to insurance, also exploiting the findings of a study on space and insurance done for the Geneva Association by EUROSAT S.A. This program was viewed by over 300'000 spectators in England in 1983. A special video tape was also produced to summarize our research on Recall Practices (1982).

In 1997 a video of about 20 minutes was prepared to introduce the book on "The Limits to Certainty" with the aim of discussing the notion of uncertainty in modern life and the economy. It is available upon request.

\subsection{Insurance in the "Service Economy"}

In the last few years, the notion that a modern economy is based essentially on the efficient organization of service functions in all sectors of activities has gained a greater momentum. The Geneva Association has followed this evolution through some specific initiatives:

- On the basis of a course on service economics given at the University of Geneva, the Association organized, thirteen years, ago a seminar for those interested in this area. In 1985 , it did gather only about a dozen of speakers and participants. One year later, in 1986, the participation jumped to 50 economists, public servants and representatives of service industries. In 1987, the Association had to restrain participation to this seminar, which is now organized regularly every year. The growing interest in the service economy increasingly leads the economic community to better understand the function of insurance. 


\section{The "Ernst Meyer Prize" * has been awarded to the following:}

1977: Dennis Moffet (Laval University, Quebec) for a thesis entitled: "Essays in the Economics of Insurance".

1978: Roland Eisen (Munich University) for a thesis entitled: "Theorie des Versicherungs gleichgewichts".

1979: Hans-Peter Sterk (Mannheim University) for a thesis entitled: "Selbstbeteiligung unter risikotheoretischen Aspekten".

1981: Yves Roy (Laval University, Quebec) for a thesis entitled: "A Stochastic Simulation Model for Reinsurance Decision-Making by Ceding Companies".

1983: Jean-Paul Cresta (Toulouse University) for a thesis entitled: "Theorie des marches d'assurance avec information imparfaite".

1985: George Szpiro (University of Pennsylvania) for a thesis entitled: "Risk Aversion in Insurance".

1986: Jean Lemaire (University of Pennsylvania) for a thesis entitled: "Automobile Insurance".

1987: Eric Briys (HEC-ISA Center, Paris) for a thesis entitled: "Theory of the Optimal Demand of Non-Life Insurance".

1988: James C. Riley (Indiana University) for a thesis entitled: "Sickness, Recovery and Death".

1989: Christian Gollier (Catholic University, Louvain) for a thesis entitled: "InterGenerational Risk Sharing and Unemployment".

1990: Wolf-Rudiger Heilmann (Karlsruhe University) for a thesis entitled: "Fundamentals of Risk Theory".

1993: Martin Nell (University of Hamburg) for this thesis on: "Versicherungsinduzierte Verhaltensänderungen von Versicherungsunternehmen-Eine Analyse der Substitutions, Moral Hazard - und Markteffekte unter besoderer Berücksichtigung der Krankenversicherung".

1994: Patrick Scarmure (University of Toulouse) on: "Essais sur la demande d'assurance en présence de risques multiples".

1996: Svein-Arne Person (Norwegian School of Economics and Business Administration) for his thesis on: "Pricing Life Insurance Contracts under Financial Uncertainty".

1997: Bert Kramer (the University of Groningen) for his thesis on: "N.E.W.S.: A Model for the Evaluation of Non-Life Insurance Companies".

1998: Sandrine Spaeter-Loehrer (University Louis Pasteur and University of Montreal) for her thesis on: "The Costs Function of the Insurer and the Prudence Behaviour of the Insured: A Theoretical Study of Optimal Insurance Contracts".

* Ernst Meyer was a founding father of the Geneva Association, as Managing Director of the

"Allianz", Munich. He died just before the start of our activity. 


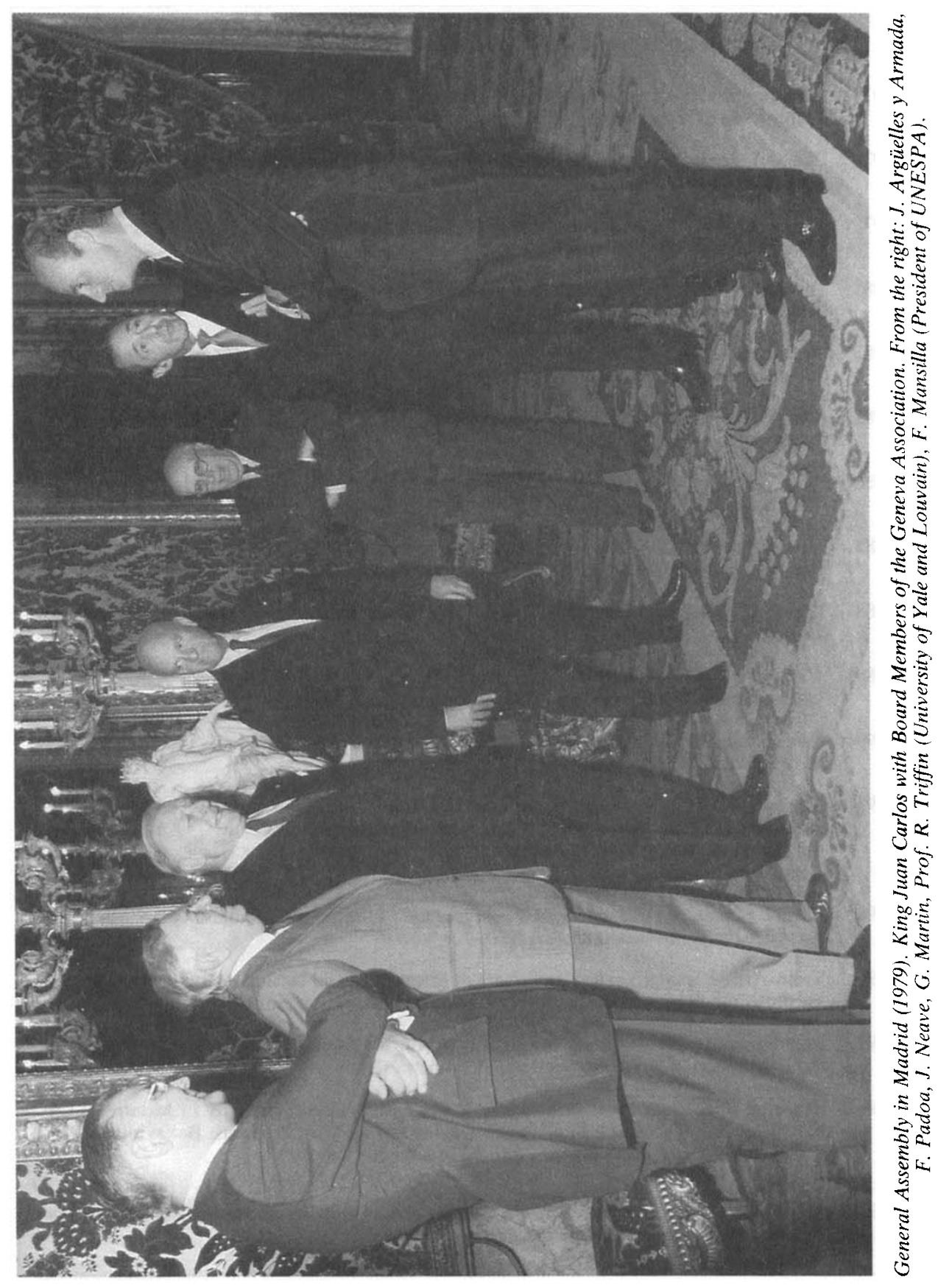


- Thirteen years ago, the Association started a small information bulletin called "PROGRES" (Research Program on Services Economics) as a link among those interested in studying the service economy around the world. From a circulation of a couple of hundred copies, there is now a request from universities, research centers, public and private organizations all around the world, approaching a circulation of 3500 copies.

- On the basis of the network established through the seminar and the "PROGRES" Newsletter, an informal organization or club was formed in 1986 in Geneva called "The Services World Forum" including key experts in the field of the service economy within international organizations, universities and other institutions.

The "Services World Forum" published a first book on "The Emerging Service Economy" with the contribution of about 20 economists and experts in 1987. Subsequently, this organization was taken over by the "Promethee" Group in Paris and by a Services Research Center in Dublin, backed by the University and by the Irish Trade Board. Further details on these activities related to the service Economy and PROGRES are described in point 4.2.1.

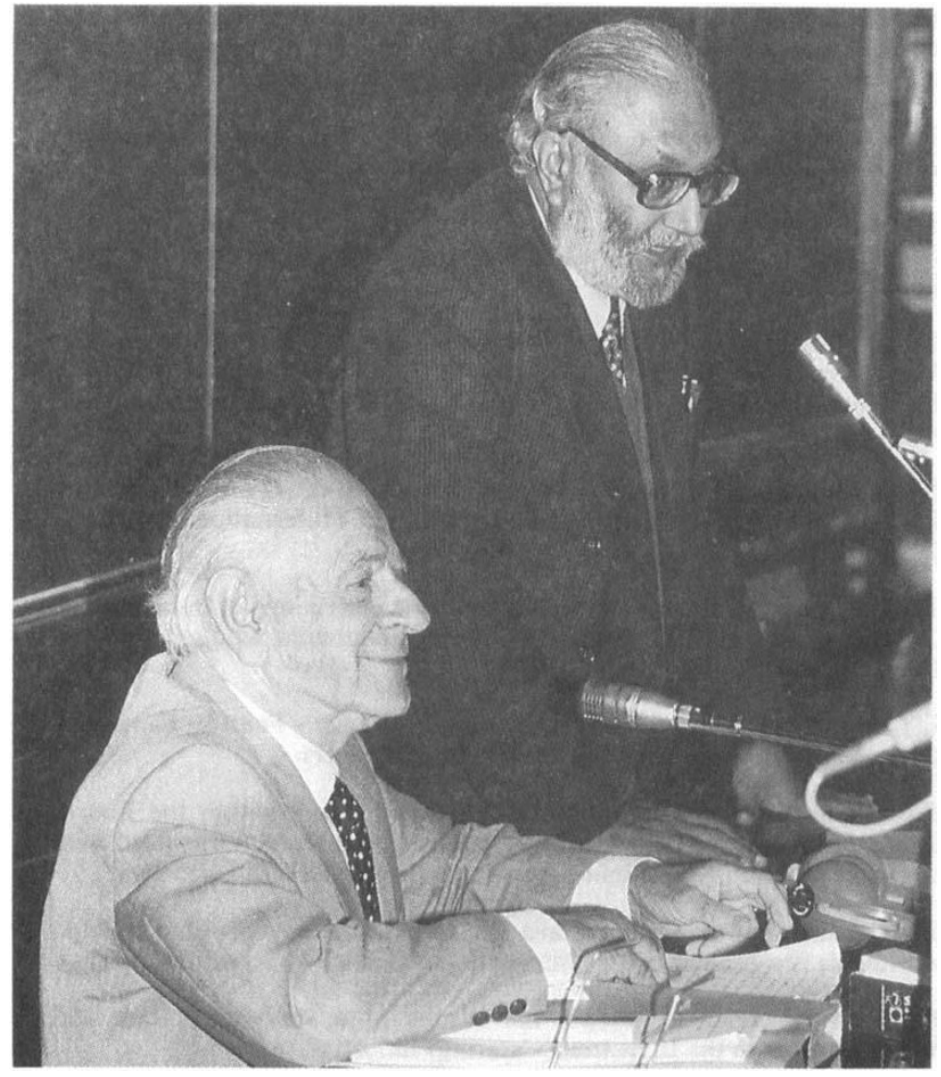

Karl Popper,

(world-known science philosopher) and Abdus Salam (Nobel Prize, Director of the International Center for Theoretical Physics) at a "Risk and Society" conference, co-organized by the Geneva Association, Trieste, September, 1987. 


\section{Risk and Society Seminars}

1987/September: First Seminar in London on "Science, Insurance and Society, with the contribution of Sir Hermann Bondi, President of the International Science Policy Foundation, London. Have contributed to the organization: Insurance and Reinsurance Research Group, London, and the International Science Policy Foundation.

1987 / October: Second Seminar in Trieste on "Uncertainty, Risk and Society". Organized with the European Branch of the International Science Policy Foundation, London, and the International Center for Theoretical Physics, Trieste.

1988 / March: $\quad$ Third Seminar in Lisbon on "Risk and Energy, Repercussions of Super Conductivity: Opportunities and Risk Management, Social and Economic Repercussions". Organized with The Gulbenkian Foundation.

1988/September: Fourth Seminar on "Aids and Insurance", given on the occasion of the 15th General Assembly of the Geneva Association in The Hague.

1988/October: Fifth Seminar in London on "Genetic Risks". Contributors were representatives from the International Science Policy Foundation, the medical and biological research and insurance sectors. Organized with the Insurance and Reinsurance Research Group, London.

1989 / January: $\quad$ Sixth Seminar in London on "Human Error and Insurance". Organized with the Insurance and Reinsurance Research Group, London.

1989/June: Seventh Seminar in London on "New Perspectives of Oil Risks. Organized with the Insurance and Reinsurance Research Group, London.

1989 /October: Eighth Seminar in Budapest on "Industrial Development and the Management of Large Environmental Risks". Organized with the International Science Policy Foundation (ISPF) and the Hungarian Academy of Science.

1990/February: Ninth Seminar in London on "Ocean Risks" with the contribution of the I.O.I. (International Ocean Institute) and I.M.O. (International Maritime Organization).

1990 / November: $\quad$ Tenth Seminar in Geneva on "Electronic Data Exchange in Insurance". Organized with ASEC (Applied Service Economics Center) and the Geneva Association.

1991 / May: $\quad$ Eleventh Seminar in London on "Airline Insurance - Feast or Famine?". Organized with the Institute of Lloyd's Underwriters.

1991/ October: Twelfth Seminar in London on "Climatic Change", within the Fourth Strategic Issues and Planning in Insurance Conference. Organized with the Insurance and Reinsurance Research Group (IRRG), London.

1991 / November: Thirteenth Seminar in Bratislava on "Biotechnology", within a large worldwide congress of ICSU (International Council of Scientific Unions).

1992/October: Forteenth Seminar to discuss the results of a study on "Risk and Vulnerabilities in the Industrial (Catering) Industry". 
1995 / September:

1996/ May:

1996/ May:
Fifteenth Seminar on "State Benefit Systems in Occupational Accident and Disability Insurance". Organized with the Cologne Re, Cologne.

Sixteenth Seminar on "Employment and Insurance". Organized with Jim Bannister Developments, London.

Seventeenth Seminar on "Flexible Employee Benefits". Organized with the Vlerick School of Management, Belgium.

Specific studies on the banking and insurance interface have started as early as 1976 (see "Etudes \& Dossiers" Nr. 11 - November 1976). This topic has subsequently been treated essentially through lectures and discussions at our seminars.

Concerning the studies on productivity and insurance, this line of research has been developed mainly by Prof. Denis Kessler at the time when he was Vice-Secretary General of the Geneva Association. The main results of this study were published in "The Geneva Papers" Nr. 59 (April 1991) and Nr. 60 (July 1991). An extension of these studies on "Productivity in Insurance and Services" was completed in 1992 by a joint venture between the University of Lille I and the University of Columbia, New York (see "Etudes \& Dossiers" Nr. 171 - September 1992).

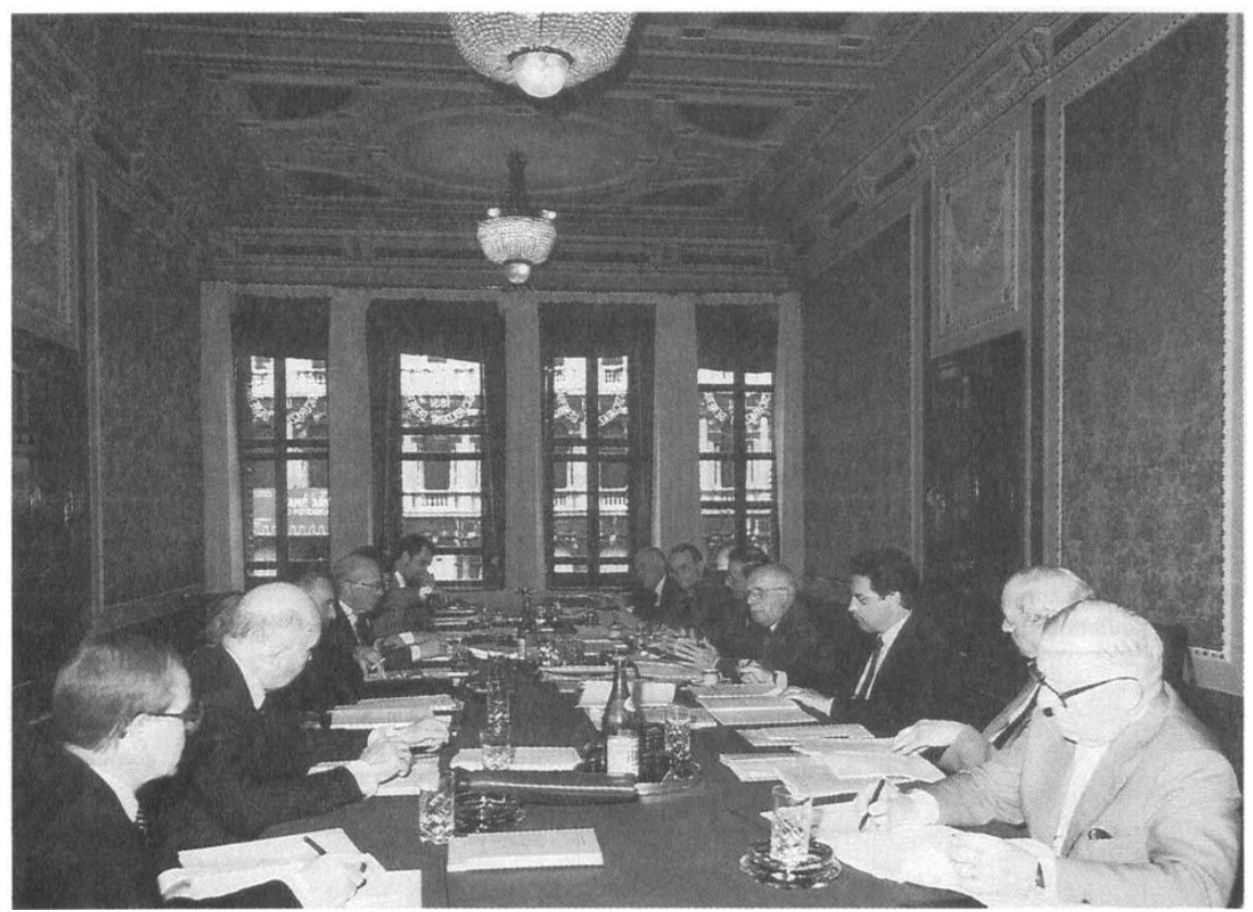

Board Meeting in Venice, Piazza San Marco, Procuratie Vecchie (1983). 


\section{Other studies in risk and insurance economics}

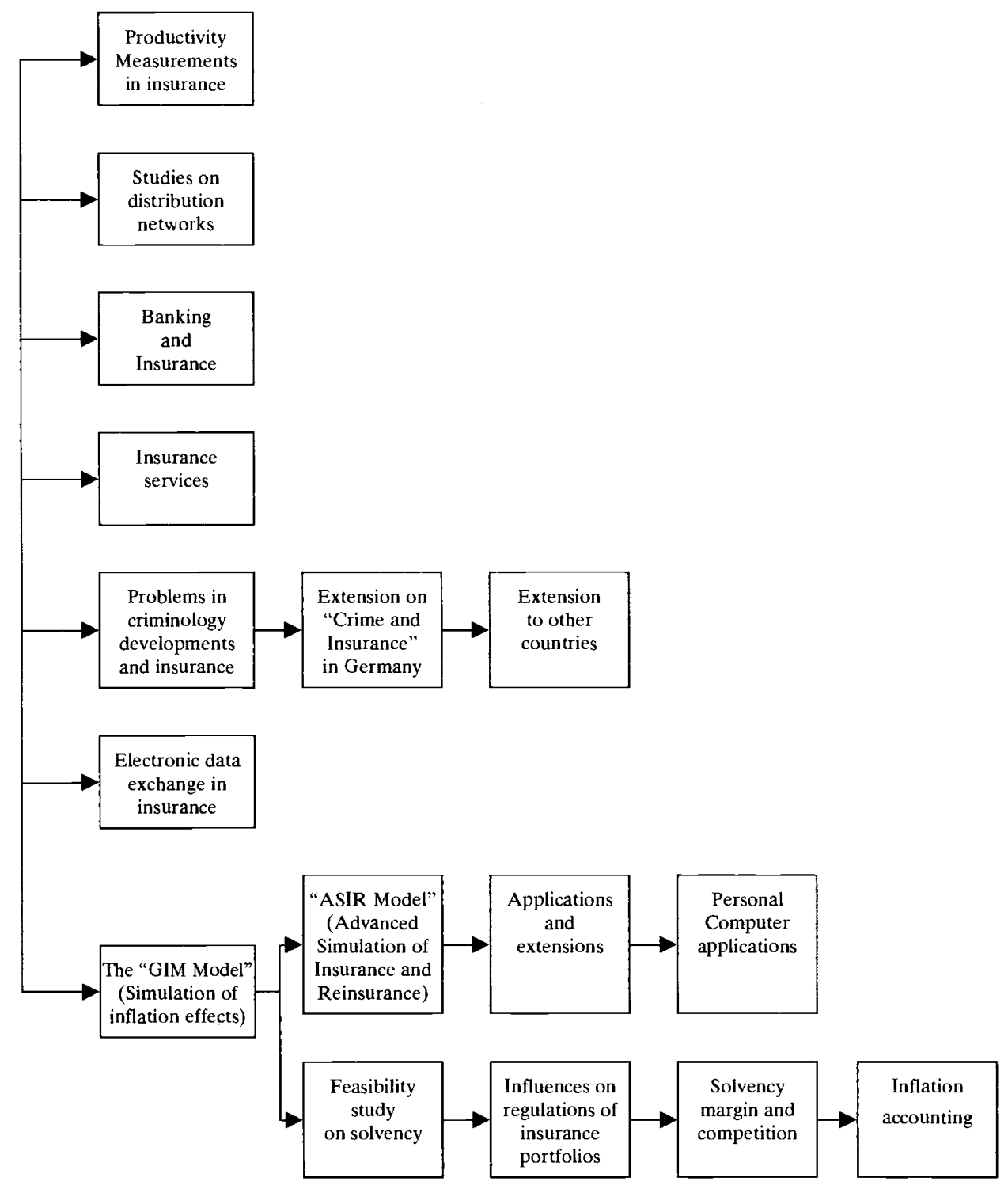


The analyses of services backing the activity of the insurance industry have been the subject of the joint venture with CAPA in Paris (see "Etudes \& Dossiers" Nr. 35 - January 1980, and Nr. 39 - June 1980).

The theme of fraud and crime in insurance has been the topic of recurrent discussions and papers presented at the seminars of the Geneva Association. In particular a study on the key issues concerning "Crime and Insurance" has been developed with the collaboration of the German Federation of Insurance Companies by Mr. G. Wittkamper, Mr. Wulff Nienhuser and Mr. K. Kammer, and published in the "Etudes \& Dossiers" Nr. 154 - April 1991.

A first study on crime and insurance was also done as early as December 1980 ("Etudes \& Dossiers" Nr. 44 - December 1980) then published in a book in London.

The Geneva Association has also contributed to the organization of three seminars in Geneva, London and Brussels on "Electronic Data Exchange in Insurance": The results of the seminar in Geneva were published in the "Etudes \& Dossiers" series, Nr. 155 - May 1991.

\section{Simulation models as tools of strategic planning:}

Strategic planning can be defined as an attempt to organize in the most rational manner all economic information which can help in making decisions on fundamental problems of relevance for companies' survival and development.

The Geneva Association initiated a study and evaluation of strategic planning within insurance companies. The results of this study were published in the United States with the collaboration of the Huebner Foundation and have also served as the basis for a conference on this theme organized in London in 1982.

Simulation techniques had a place on the agenda of the Association from almost "day one". The first simulation model resulted in the Geneva Insurance Model (GIM) based on a study on the effect of inflation on motor insurance. Through contact with the University College of North Wales, the idea emerged from the "Advanced Simulation Model of Insurance and Reinsurance operations" (ASIR).

ASIR can produce a selection of printed reports in both tabular and graphical format. These range from summary time series of company-wide statistics to detailed reports on a single insured risk. ASIR allows both deterministic and stochastic simulations to be run, according to the application.

The first PhD thesis in economics on ASIR has been awarded at the University of Rome. Eight universities in England, Italy, the Netherlands, France, Germany, Switzerland, United States and Australia have pursued research and student education based on ASIR.

Insurance companies have also used and developed ASIR for their own practical applications. 


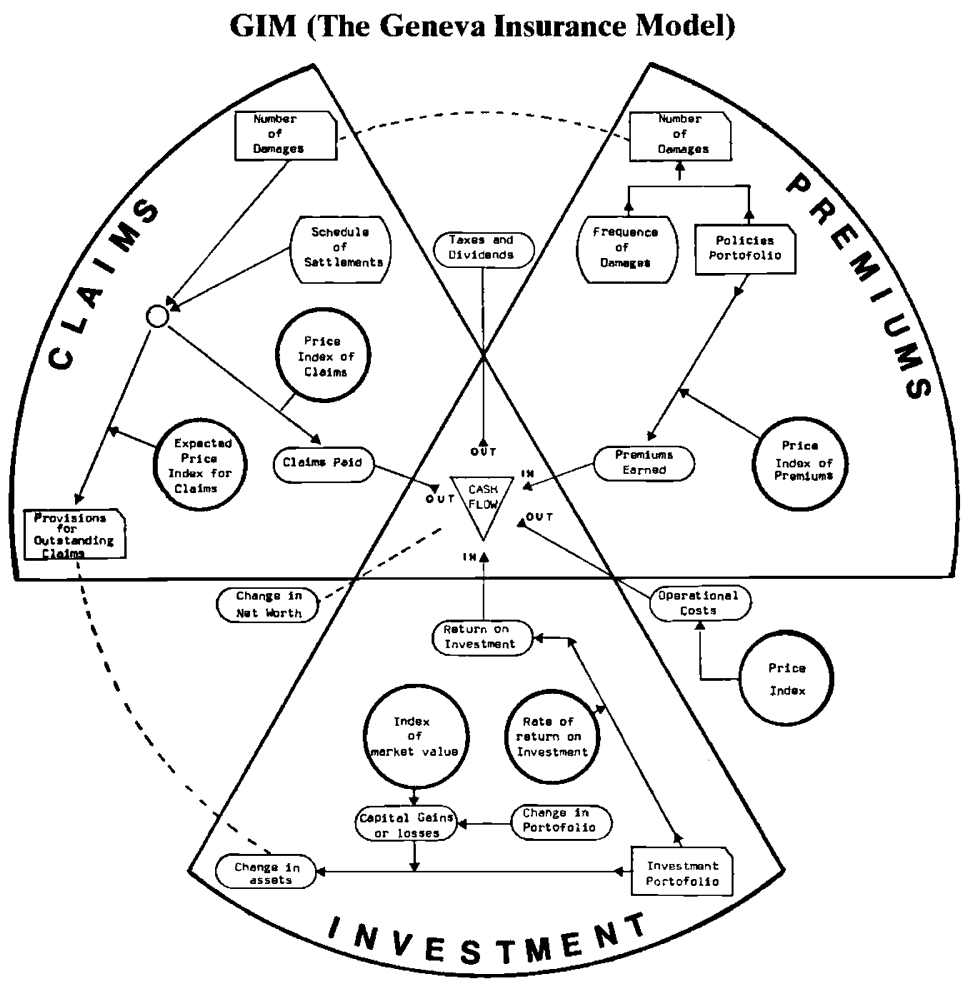

The Advanced Simulation Model on Insurance and Reinsurance (ASIR)

ASIR is a comprehensive and flexible modelling system specifically designed for insurance and reinsurance applications. With ASIR a user can simulate the behavior of an insurance company under a wide range of economic conditions. Results from ASIR can encompass the worldwide operations of an insurance company, or can concentrate on one country, a branch or even just a single risk.

In any single simulation run, ASIR has the power the cope with:

- up to 9 insurance or reinsurance companies

- up to 40 different kinds of risk portfolios

- up to 3 separate reinsurance treaties per risk

- up to 9 different kinds of treaties, covering both proportional and non-proportional reinsurance

- up to 20 countries and currencies

- up to 40 different investment portfolios

- a very flexible specification of each country's operating and regulatory environment

- any duration of simulation run. 


\section{Methods of Work and Organization}

The Association was not founded for the purpose of studying problems inside the insurance field - these problems are already the subject of many studies by specialists in the profession.

On the contrary, the Association's vocation is to expand the field of vision of the insurance profession and, in so doing, to expand and test new fields of action. Thus, the researchers were often deliberately chosen from among the world of economists (complemented by the contribution of insurance experts), a point which contributes, moreover, to placing the Geneva Association in a position of credibility vis-a-vis the world outside insurance as regards the economic study of risks. But this strategy can be conceived only in a long-term perspective, because of the constraints imposed by the gap between the world of economics and the world of insurance. The Association found itself obliged to promote the development of a duplicate structure of receptivity: among economists, so that studies on risk and insurance would receive the attention they merit; and among insurers, so that research undertaken outside the insurance could be adequately utilized.

An effort to promote the economic analysis of risk and insurance is being made in the case of the two types of institutions which offer research potential in this field: the universities, on the one hand, and the professional research centers, on the other.

The former dispense teaching in economics which too often ignores the study of insurance. This is due to many reasons which the Association has tried to analyze in detail. Such an analysis is necessary not only because the gap between economic science and insurance makes the carrying out of studies more difficult but also because it is preoccupying in a period in which the economic importance of the risks dealt with by insurance are growing rapidly. It prevents those who take decisions in the economic world in general from appreciating certain important elements of the real situation and from engaging in dialogue with the insurers, whose function is precisely to study these elements.

The professional research centers had hardly, 30 years ago, any experience of insurance because the insurers hitherto have rarely had recourse to them. And yet, more and more often, these centers are being called upon by international institutions, by governments and by industrial undertakings to analyze important problems of organization and economic planning and decision. The leading one among them employs 6'000 people operating throughout the whole world. It is in this type of institution that there can best be created a research capability on problems arising at the interface between insurance and all other economic activities but the researchers must first acquire, through pilot-studies, the expertise they still lack in this field. That is why, even if insurance has not the same need of economic research as other sectors, it is important that it takes care to make use of the world of professional research in order to gain acceptance therein. This objective is closely interrelated with the objective of stimulating serious and useful research programs.

The obstacles encountered by the Association in its activities resided not only in the training of researchers. They also arose in connection with the ability of insurance to make use of economic research which is not always directly related to problems inside the profession. Research itself, in order to be usefully organized and exploited, requires a very specific set of professional research capabilities. 
Insurance is a very ancient activity which, until very recently, felt no need to examine too profoundly the economic aspects of its activities: the economists who entered this sector were very rare. However, the objectives sought by the members of the Geneva Association through its activities cannot be achieved unless insurance learns to make better use of and learn to select the economic tool than it has done in the past. An important task for the Association is to promote such a development, to act as a stimulus within the profession itself. In the same way as it is bringing the world of research university or professional to an awareness of the economic reality of insurance, the Association is seeking by its action to encourage insurance to place itself in the context of the economy in general, to conceive its role in relation thereto and to assimilate its methods and its language.

This is a delicate role but it fits in well with the essential role of research: research does not make problems disappear but, rather, places them in a harsher and more revealing light, thus increasing the information available to the person who is called upon to resolve them. Such additional information brings with it both a greater capacity to find understanding outside the profession - consumers, public authorities, and the discovery of new fields of action or new methods of work.

During its early years of activity the Geneva Association devoted its efforts essentially to make contact with the world of research. The initial results obtained have been sufficiently satisfactory to enable the efforts to be directed henceforth towards deepening and improving the research paths chosen rather than towards expanding the field of action.

Moreover, the Association, at the urging of the Board, has applied itself to reinforcing its contacts with the users of its studies.

It must be stressed that in fact, through a dense network of personal contacts with insurance companies, not a single study has been proposed, discussed and diffused without several verifications with insurance experts who have willingly provided their help and advice.

It must be understood that the normal program of research requires many efforts and professional understanding at three distinct and different levels:

a) The definition of special aims in research programs: This is an essential stage which can, in certain cases, require more time than the execution of the research itself. During the last twenty-five years, a constant effort of discussion and verification with our members and their collaborators has been needed to define research aims and put them into practice. It is to this task that more than half of all contacts undertaken personally by the Secretary General and his direct collaborators is consecrated. These contacts very often spread to areas outside the Geneva Association and indeed insurance itself.

b) The execution and control of research programs: This second essential part of our work has been followed by means of continuous contacts between researchers and insurance experts. For some studies, these contacts are spread over two years or even more.

c) The results of any research cannot be really usefully exploited if they are not screened carefully by the user: the arguments must be verified, the overall results must be applied to specific conditions within each company. All studies need time for the 

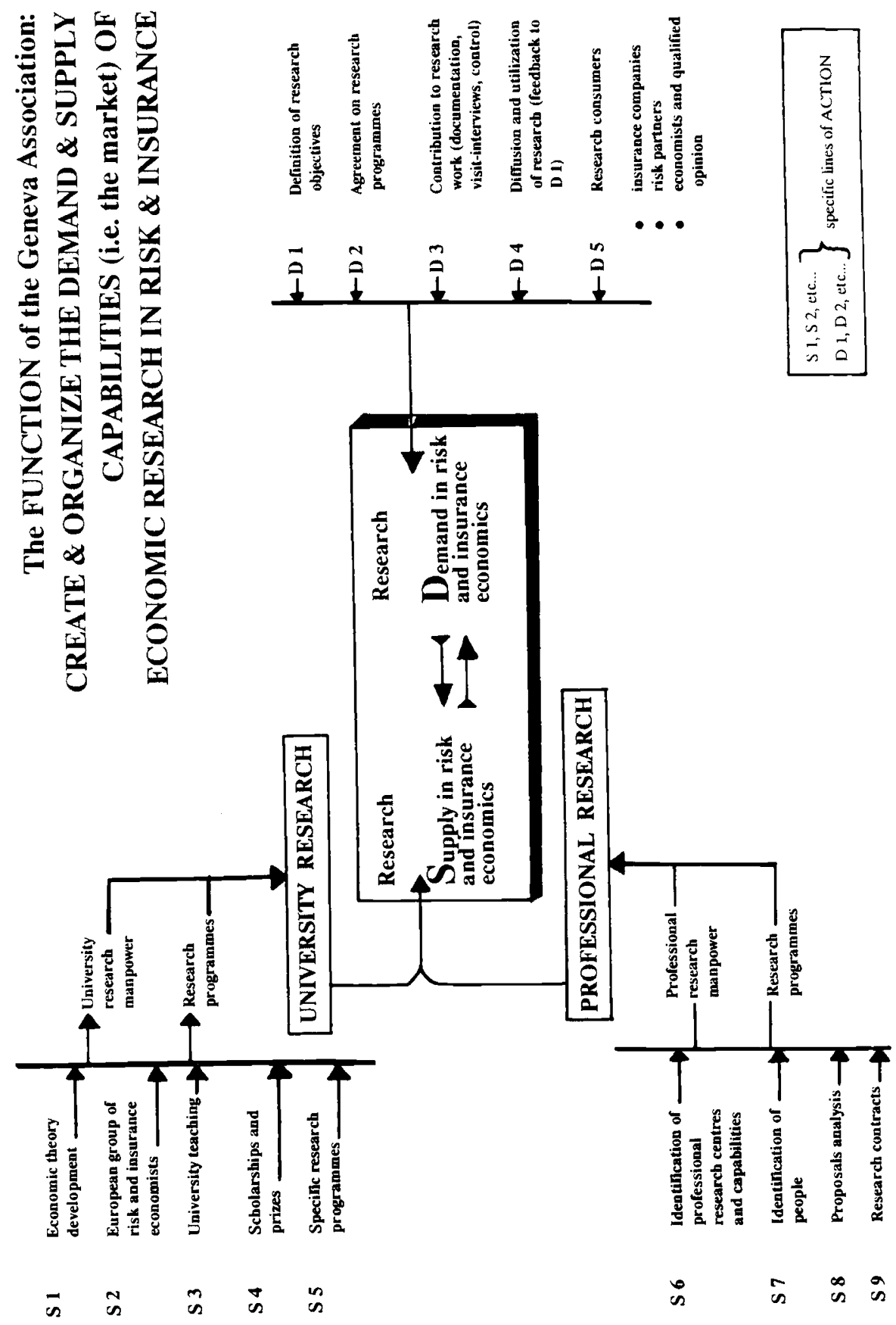
digestion of results: This can easily take more than one-quarter of the time allocated for the research itself.

It is then essential for insurance companies to develop their own capabilities for selection and utilization of information and economic research. A clear progress has been done in this direction and the door has been opened to improve the professional attitude in this particular area of management.

Research, if done professionally, is quite a complex area of management but it goes back to one fundamental notion: the measuring of result compared to the resources available.

The available resources in terms of manpower of the Geneva Association have been for these 25 years the following:

- A full-time Secretary General who could benefit from his previous professional activities of Director of the techno-economic research division of the Battelle Institute in Geneva, which is the leading world organization for private contract research and where all the studies have to be financed by concerned companies in all sectors and activities in the world.

- One to four Vice-Secretary Generals who, in fact, have been head of projects or have followed a specific line of research. None of these Vice-Secretary Generals have worked full-time but have benefited from a major activity in a complementary sector (university, national and international insurance federations, engineers experts in the field of industrial and waste management, insurance consultants and economists). At present, out of the four Vice-Secretary Generals, only two are paid part-time and the others benefit from a reimbursement of expenses only when they are actually performing a specific task for the Geneva Association.

- A part-time collaborator as editor of the Geneva Papers and coordinator of the Internet site.

- A series of experts (about twenty in the course of the 25 years) who have acted most of the time as non-paid advisors or even head of projects.

- One to four part-time secretaries.

- A series of occasional contributors, hired according to the necessity for all sorts of clerical or organizational work.

It must be noted that all the publications of the Geneva Association are prepared in our office (with a total surface of $160 \mathrm{~m}^{2}$ ) and that only the Geneva Papers and the books are printed, of course, outside. Just to give a point of reference: The Xerox machine in our office has always been the one beating all the records of monthly copies made among Xerox customers in the whole canton of Geneva, including all the agencies of the United Nations! This is also due to the fact that the model used has been normally of a smaller standard and adapted to our type of work without the necessity of having a specialist to use them. We must also add that most of the seminars and lectures organized in Geneva and even outside (including the General Assembly) have been largely managed by the staff in our office. 
Of course all this would have never been possible without the contribution of several dozens of free contributors and organizers from several insurance companies as well as from outside organizations.

We should also underline thankfully that the Swiss Reinsurance Company in Zurich has done the accounting work for the Geneva Association for free and for all these years.

\section{From 1973 to 1998, the Geneva Association has organized:}

- 960 interviews of at least one hour for our various studies with industrial companies, 420 with universities and research centers, 540 with other financial institutions, insurance companies and risk management organizations;

- 162 meetings (seminars, colloquia and conferences) for a total of over 6'000 participants;

-300 universities have been contacted, 140 of which on a continous basis:

- It has published 88 issues of the "Geneva Papers - Issues and Practice", 18 issues of the "Geneva Papers - Theory", 215 "Etudes \& Dossiers", 485 Information Letters of different kinds; furthermore,

- Information on the activity of the Association and on insurance economics questions has been provided to about five thousand people, including those using the Association's library;

- The Geneva Association has granted or negotiated research work with 56 university researchers: 17 Ernst Meyer Prize, 30 scholarships, 11 contributions for publications, 14 small research contracts;

-38 contracts have been negotiated with professional researchers;

- 315 lectures have been delivered in the name of the Geneva Association (by its Presidents, the Secretary General and the Assistant Secretary Generals);

- A specialized library on risk, uncertainty and insurance economics has been constituted in Geneva and is freely accessible to researchers.

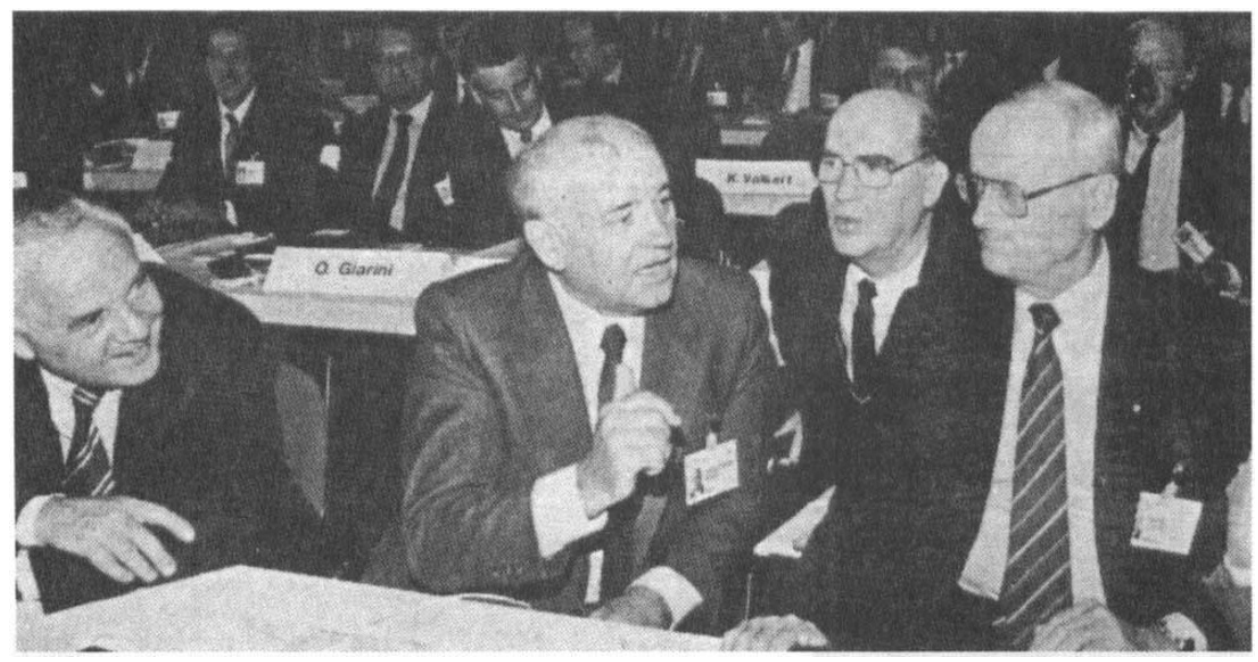

Discussion on Risk and Society at the Club of Rome - I.P.I. Conference in Wolfsburg. First row: Michail Gorbatschow, Carl H. Hahn (President of Volkswagen), Manfred Stolpe (President of the "Land"). Second row: Orio Giarini (The Geneva Association). 
The key for all our achievements has been the essential ingredient of any managerial enterprise: motivation. The perception of the fact that insurance activities are becoming a key issue in the modern economy has been the fundamental ingredient upon which to stimulate energies and interest.

It can be said today, without any danger of over-statement, that the Geneva Association, while being for instance, the smallest international research organization in Geneva and one of the smallest in the world, has probably achieved results comparable to those of much larger organizations and foundations, with a minimum budget. In fact, the total budget in 1998, of 1'500'000 Swiss Francs, is in real terms only higher by $10 \%$ with respect to that of 1973-74. In 1998, each member is paying a fee which is, in real terms, only $40 \%$ of the fee paid in 1973 . There is no additional or special source of income, except the subscriptions to The Geneva Papers on Risk and Insurance.
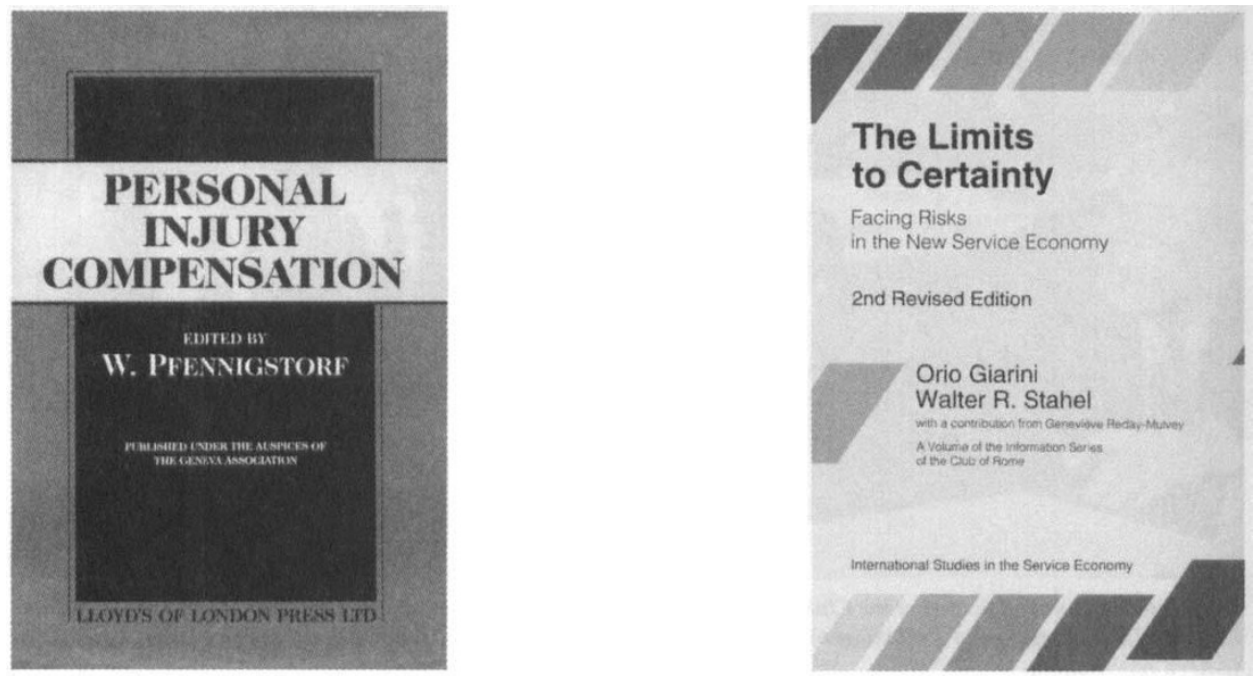


\section{The Geneva Association publications}

\section{THE GENEVA PAPERS} ON RISK AND INSURANCE ISSUES AND PRACTICE

The aim of this quarterly review is to provide quality back-up to economic research as regards risk, uncertainty and insurance.

The papers presented in each issue are edited from articles which have been submitted for publication, and from completed research financed by the Association, or from other sources.

Publication: 4 times per year.

Circulation: 2’200

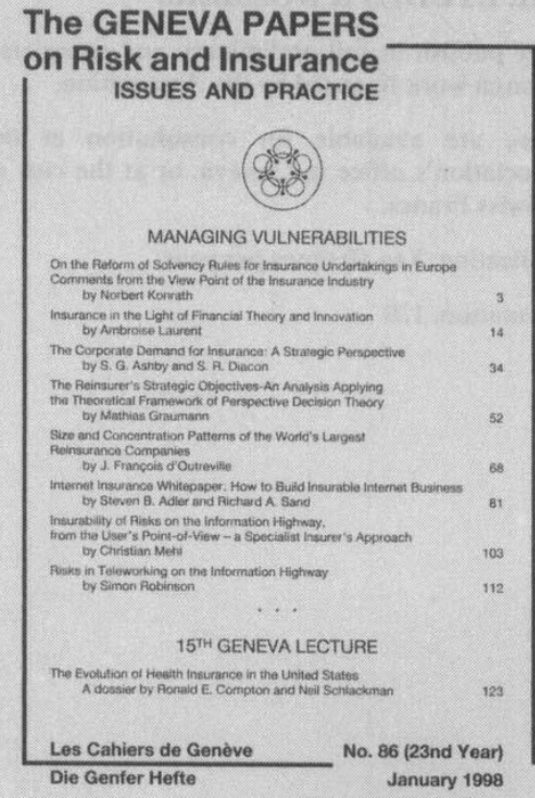

The GENEVA PAPERS

on Risk and Insurance Theory-

Volume 22, No. 2

December 1997

Specid thave on Agmmetic indormution

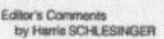

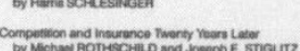

Complase Vursus incomplete insurance Contracts under

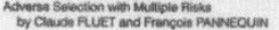

Pocting and Separaing Equabra in insurence Maktets

with Adverse Selection and Distibution Costa

by Man Chaves RoC Jeen

Explaining insurance Potroy Provitions via Adverpe

Solection

Ful hsurance, Bepeoien Updated Pramima, and

Alichard WATI and Francisco I, vaZOUEZ

imperifoet Aguncy and the Pagatation of Honptish

\section{THE GENEVA PAPERS ON RISK AND INSURANCE - THEORY}

The purpose of this journal is to support and encourage research in the economics of risk, uncertainty, insurance and related institutions by providing a forum for the scholarly exchange of findings and opinions.

Unsolicited research papers, comments and book reviews are welcomed and both theoretical and empirical papers are encouraged. Each submitted manuscript is reviewed by an anonymous referee and a member of the Editorial Board.

Publication: Twice per year.

Circulation: 800 


\section{THE ETUDES \& DOSSIERS}

They publish in full preliminary and completed research work financed by the Association.

These are available for consultation at the Association's office in Geneva, or at the cost of 45 Swiss Francs.

Publication: 8 to 10 times per year.

Circulation: 120

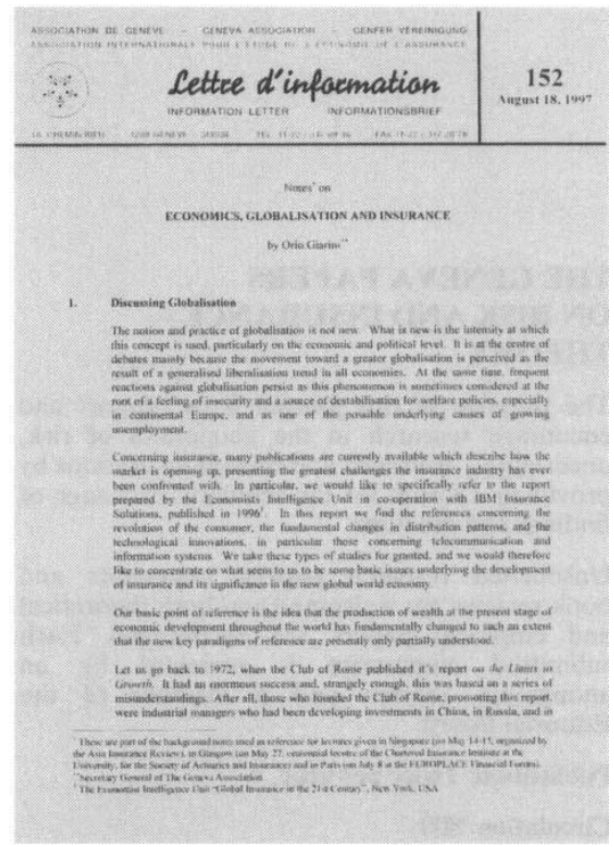

\section{ÉTUDES ET DOSSIERS}

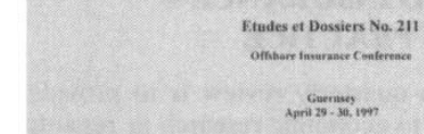

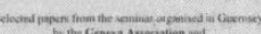

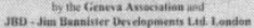
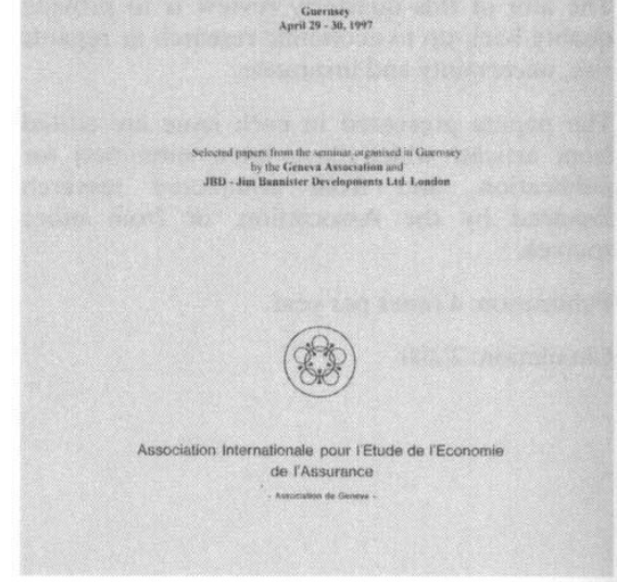

\section{INFORMATION LETTERS - LETTRES D'INFORMATION}

Available upon request from the Geneva Association.

They provide information on research or meetings supported by the Association, including occasional articles on insurance problems.

Publication: 6 to 8 times per year.

Circulation: 1'500 


\section{THE NEWSLETTER}

Information bulletin of the European Group of Risk and Insurance Economists.

It provides information on academic activity in the field of risk and insurance, mainly as regards research, publications and lectures.

The Newsletter is available upon request from the Geneva Association.

Publication: Twice per year.

Circulation: 3'500

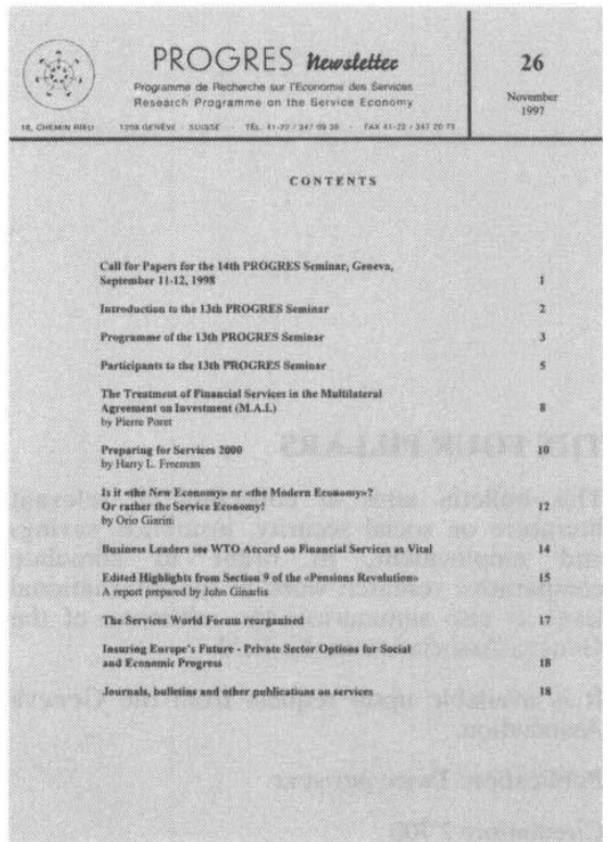

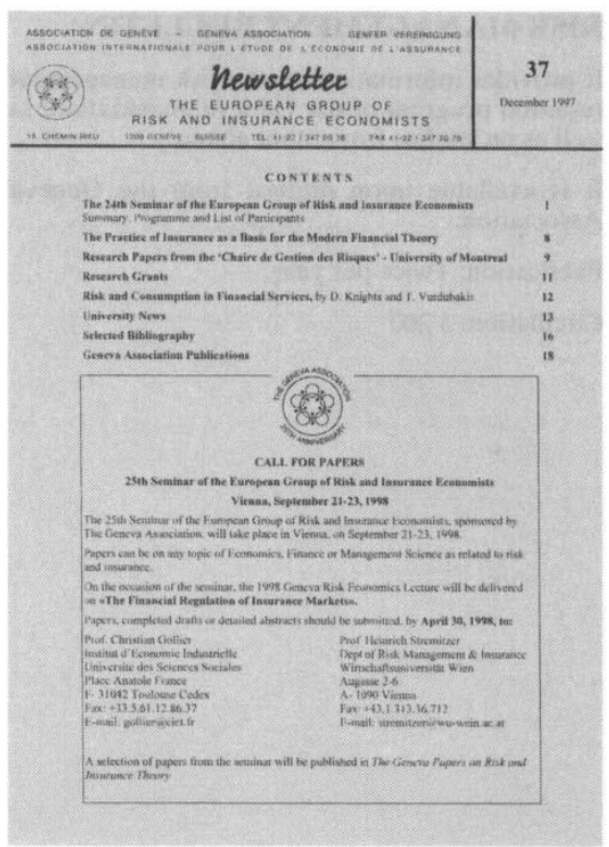

\section{PROGRES}

Newsletter on the program of research on the service economy.

It is available upon request from the Geneva Association.

Publication: Twice per year.

Circulation: 3'500 


\section{RISK MANAGEMENT BULLETIN}

It provides information on the risk management researcfi program of the Geneva Association, as well as on studies from other sources.

It is available upon request from the Geneva Association.

Publication: Twice per year.

Circulation: 3'200

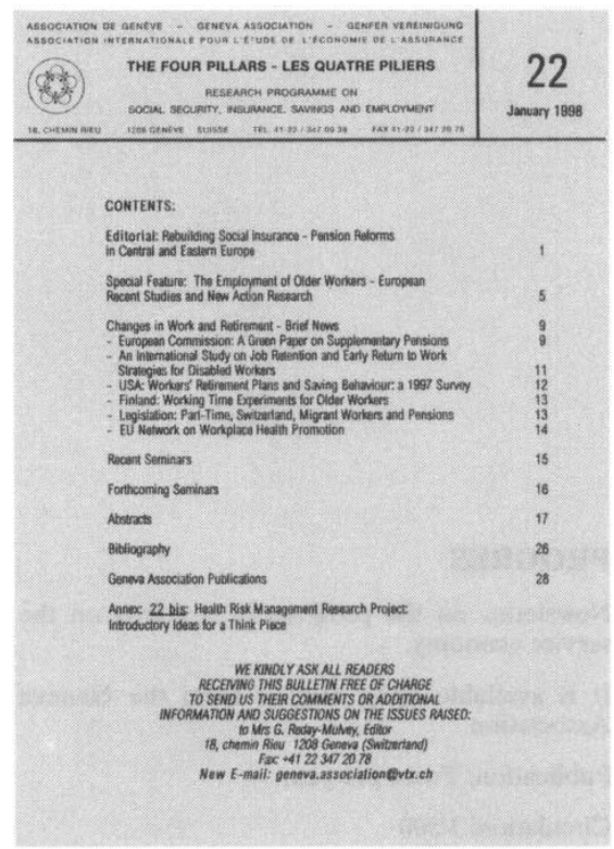

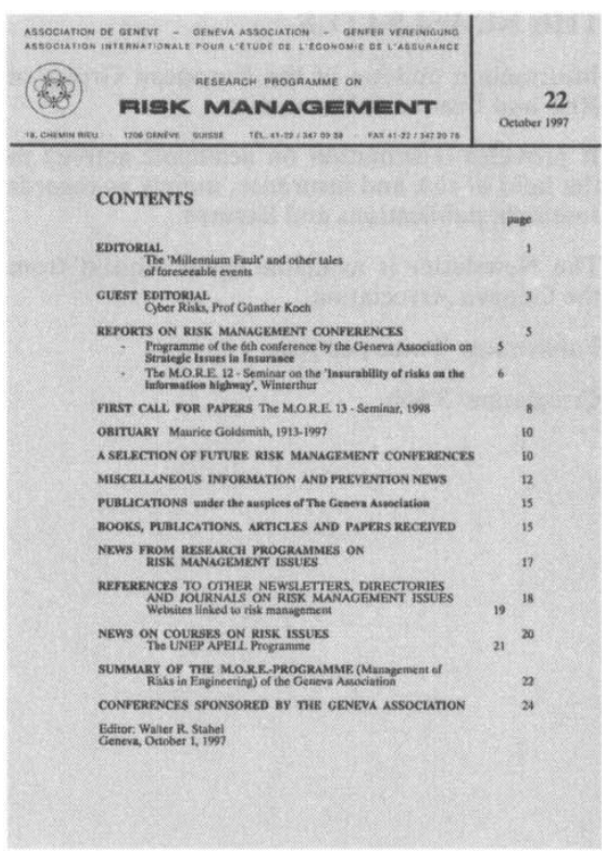

\section{THE FOUR PILLARS}

This bulletin aims at collecting all relevant literature on social security, insurance, savings and employment, in order to stimulate comparative research work at the international level. It also summarizes the initiatives of the Geneva Association in this field.

It is available upon request from the Geneva Association.

Publication: Twice per year.

Circulation: 2700 


\section{WORLD FIRE STATISTICS BULLETIN}

This bulletin is a tool to collect data and distribute information concerning the total economic costs of fire worldwide, with the collaboration of a special office of the United Nations.

Publication: Twice per year.

Circulation: 200

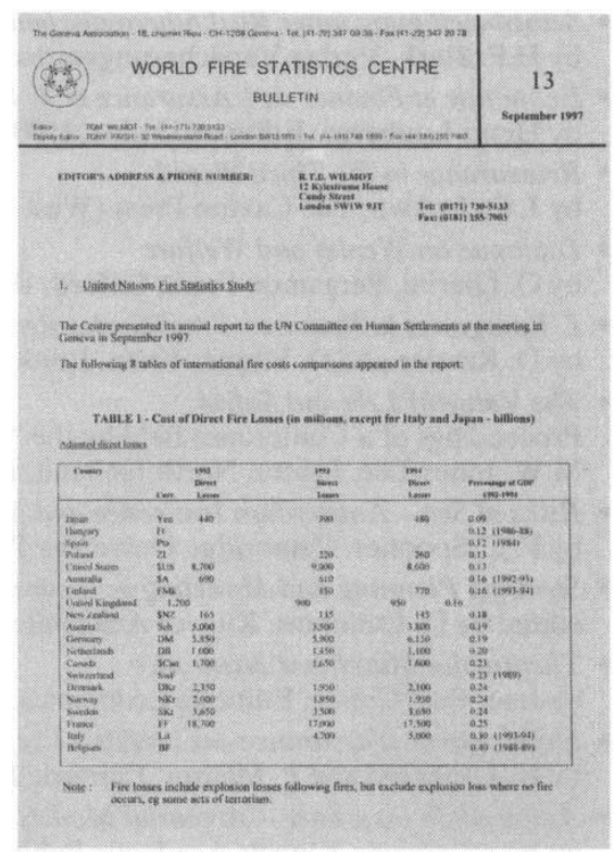

\section{Publications benefiting from the support of the Geneva Association}

- L'Enseignement de l'Economie du Risque et de l'Assurance en Europe by Henri Loubergé, Institut Universitaire d'Etudes Europeennes de Geneve, 1976, 144 p.

- Versicherungs- und Risikowirtschaftslehre in Europa by Henri Loubergé and H. Kaplanek Verlag Institut fur Versicherungswirtschaft, St. Gallen, 1978, 264 p.

- The Teaching of Insurance Economics and Risk Management in Europe by Penny Stark, University of Nottingham, 1980, 260 p.

- Les Nations Unies et l'Assurance-Reassurance by R. Krommenacker, Librairie Generale de Droit et de Jurisprudence, Paris, 1975, 215 p.

- Die betriebliche Altersversorgung by E. Riedlbauer, Verlag Versicherungswirtschaft e. V., Karlsruhe, 1975, 112 p.

- Trends in Life Insurance and Related Saving Schemes by S. Wynn, Associated Business Programmes, London, 1875, 120 p.

- Alterssicherung und Einkommensverteilung by W. Schmahl, Verlag J. C. B. Mohr, Tubingen, 1977, 480 p.

- The Effect of Transaction Costs on the Demand for Life Insurance by D. Moffet, Universite de Laval, Quebec, Canada, 1977, 111 p.

- Insurance Management in Africa by J. O. Irukwu, The Caxton Press (West Africa) Limited, Ibadan, 1977, 425 p.

- Theorie des Versicherungsgleichgewichts by R. Eisen, Duncker \& Humblot, Berlin, 1978, 183 p. 
- Selbstbeteiligung unter Risikotheoretischen Aspekten

by H.F. Sterk, Verlag Versicherungswirtschaft e.V., Karlsruhe, 1979, 278 p.

- Economie et Finance de l'Assurance et de la Réassurance

by Henri Loubergé, Editions Dalloz, 1980, 318 p.

- Reinsurance in the Third World

by J. O. Irukwu, The Caxton Press (West Africa) Limited, Ibadan, 1980, 308 p.

- Dialogue on Wealth and Welfare by O. Giarini, Pergamon Press, Oxford, 1980, 386 p.

- L'Epargne et la Retraite - l'Avenir des Retraites préfinancées by D. Kessler and D. Strauss-Kahn, Editions Economica, Paris, 1982, 183 p.

- The Value of Life and Safety Proceedings of a Conference held by the "Geneva Association" M.W. Jones-Lee, Editor, North Holland, 1982, 309 p.

- Risks at Sea-Amsterdam Insurance and Maritime Europe by F. C. Spooner, Cambridge University Press, 1983, 320 p.

- Strategic Planning and Modeling in Insurance edited by D. Cummins, Kluwer Academic Publishers, Hingham, MA, 1984, 336 p.

- Theorie des Marches d'Assurance by Jean-Paul Cresta, Editions Economica, Paris, 1984, 232 p.

- Financement et assurance des credits a l'exportation by H. Loubergé and P. Maurer, Librairie Droz, Geneve-Paris, 1985, 502 p.

- Automobile Insurance - Actuarial Models by Jean Lemaire, Kluwer Academic Publishers, Dordrecht, 1985, 252 p.

- Insuring and Managing Hazardous Risks: From Seveso to Bhopal and Beyond by P. R. Kleindorfer and H. C. Kunreuther, Springer-Verlag, Berlin, 1987, 543 p.

- The Emerging Service Economy edited by O. Giarini, Pergamon Press, Oxford, 1987, 298 p.

- La Suisse et le Marche Commun face a la liberalisation des services by O. Giarini and J. R. Roulet, Institut Universitaire d'Etudes Europeennes, Geneve, 1988, 63 p.

- L'Europe face a la nouvelle economie de service edited by O. Giarini and J.R. Roulet, Presses Universitaires de France, Paris, 1988, 240 p.

- Special Issue of "ECU" - Assurance et ECU 1989 - IV Editions ECU Activities, Brussels, 1989.

- Sickness, Recovery and Death by James C. Riley, The Macmillan Press Ltd., New York, 1989, 295 p.

- Risk, Information and Insurance edited by H. Loubergé, Kluwer Academic Publishers, Dordrecht, 1990, 274 p.

- Personal Injury Compensation edited by W. Pfennigstorf, Lloyd's of London Press, London, 1993, 213 p.

- The Limits to Certainty - Facing Risks in the New Service Economy by $\mathrm{O}$. Giarini and W. Stahel Kluwer Academic Publishers, Hingham, MA, 2nd edition, 1993.

- Gradual Retirement in the OECD countries by Geneviève Reday-Mulvey and Lei Delsen Asugate Publishing Company Ltd, Grower House, Croft Road, Aldershot, Hampshire, GUII 3HR. 


\section{From the Scrapbook of The Geneva Association:}

Sergio Siglienti (President, Instituto Nazionale delle Assicurazioni $\operatorname{SpA}$ ), Claude Bebear (Chairman and CEO, AXA Group, Paris and VicePresident of the Geneva Association). General Assembly of the Geneva Association, Bordeaux, 1996.
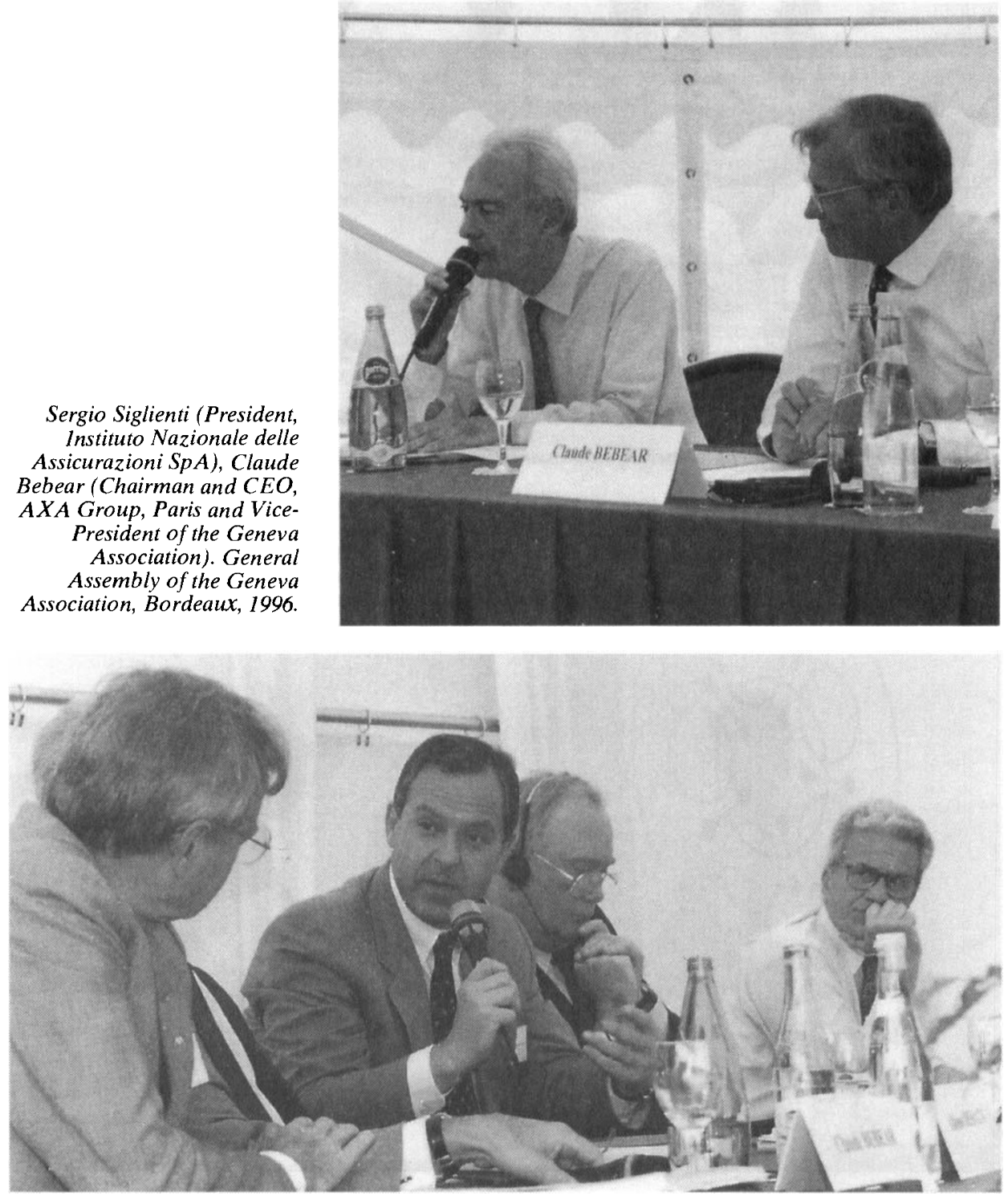

From left: Claude Bebear (Chairman and CEO, AXA Group, Paris and Vice-President of the Geneva Association), Lukas Mühlemann (Managing Director, Swiss Re, Zurich), David Gilchrichst (Chairman, R. J. Kiln \& Co. Ltd, London), Antoine Jeancourt-Galignani (Chairman and CEO, AGF). General Assembly of the Geneva Association, Bordeaux, 1996. 


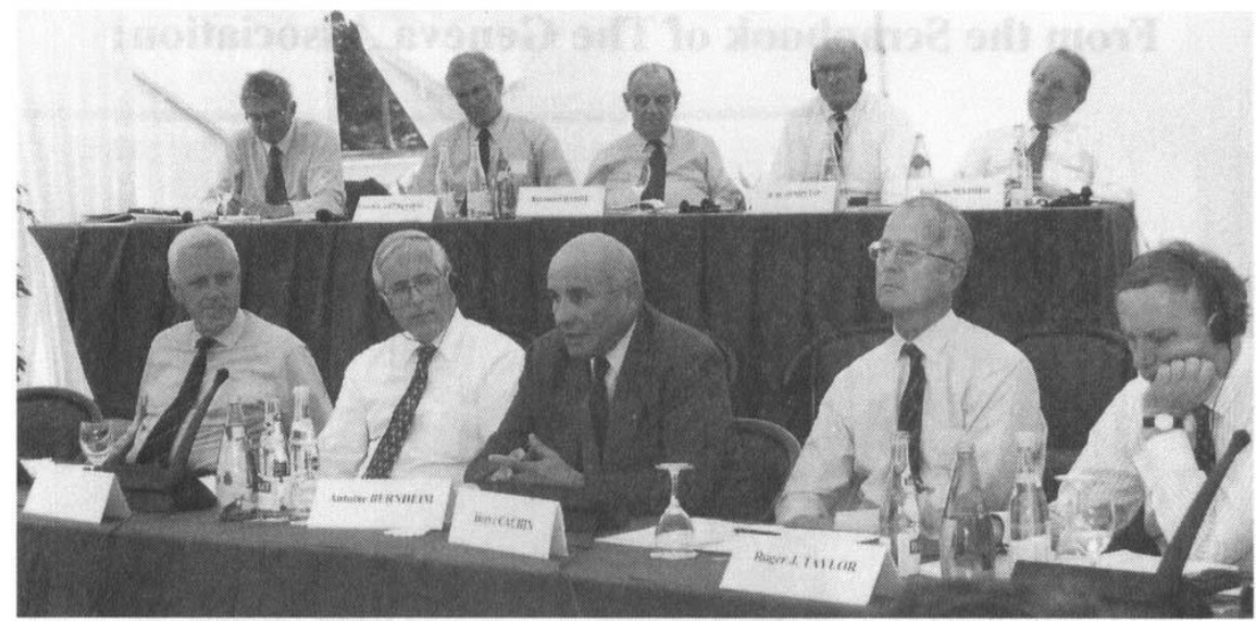

Antoine Bernheim (President, Generali) addressing the General Assembly of the Geneva Association in Bordeaux, 1996.

From left - top row: Michel Albert: (Member of the Monetary Policy Council of the Banque de France), Ulrich Cartellieri (Member of the Board, Deutsche Bank), Raymond Barre (former Prime Minister of France and Honorary President of the Geneva Association), Richard H. Jenrette (Senior Advisor, Donaldson, Lufkin \& Jenrette, New York), Graham Mather (President, European Policy Forum, London). - From left - bottom row: Prof. Niels Thygesen (Advisor to the Central Bank of Denmark), John G. Walsh (Executive Director, The Group of Thirty), Antoine Bernheim (President, Generali), Hervé Cachin (President, SAFR, Paris), Roger Taylor (Group Chief Executive, Sun Alliance Group).

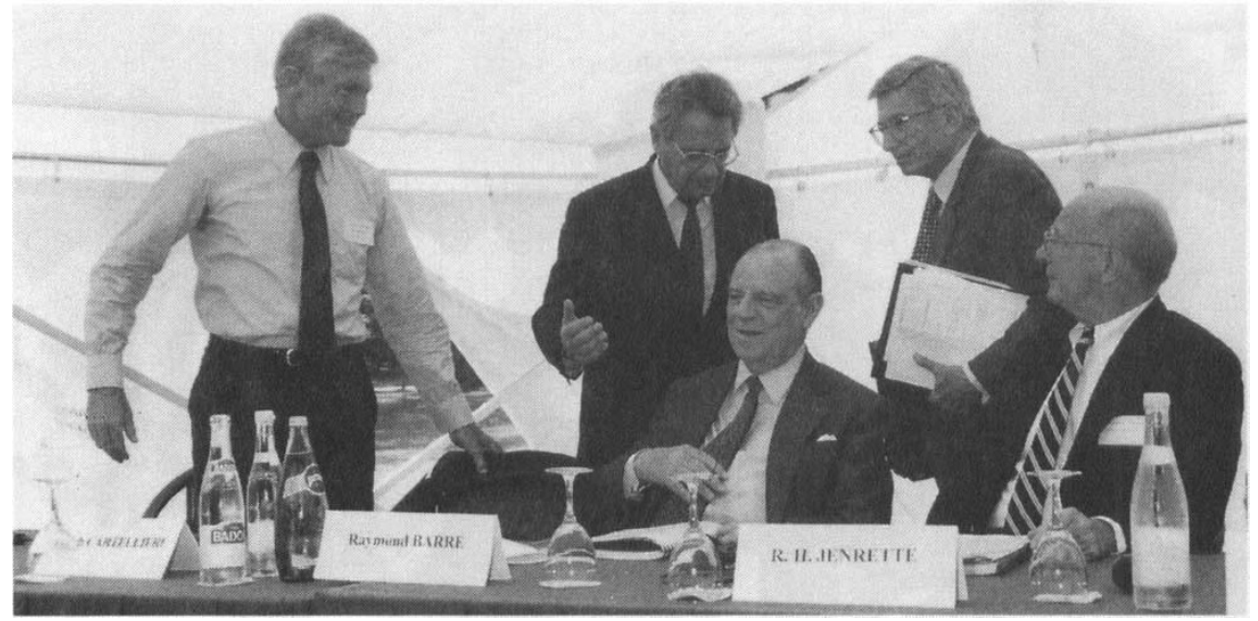

General Assembly of the Geneva Association, Bordeaux, 1996.

From left to right: Ulrich Cartellieri (Member of the Board, Deutsche Bank), Orio Giarini (Secretary General, The Geneva Association), Raymond Barre (former Prime Minister of France and Honorary President of the Geneva Association), Michel Albert (Member of the Monetary Policy Council, Banque de France), Richard H. Jenrette (Senior Advisor, Donaldson, Lufkin \& Jenrette, New York). 


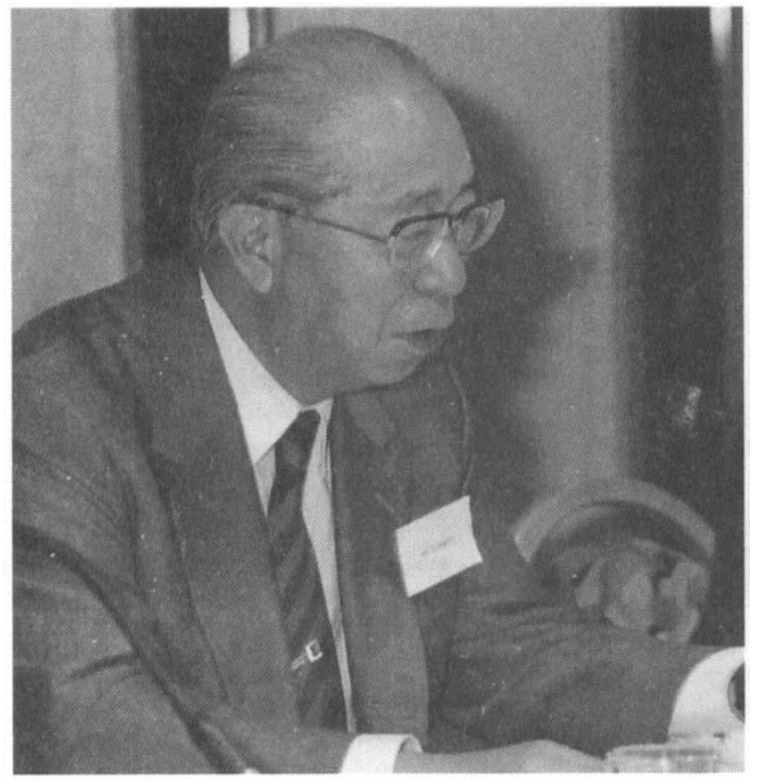

Mr. Saburo Okita (former Chief Economic Advisor to the Japanese Government, former Minister of Foreign Affairs of Japan and Member of the Board of the Club of Rome). General Assembly of the Geneva Association, Brussels, 1990.

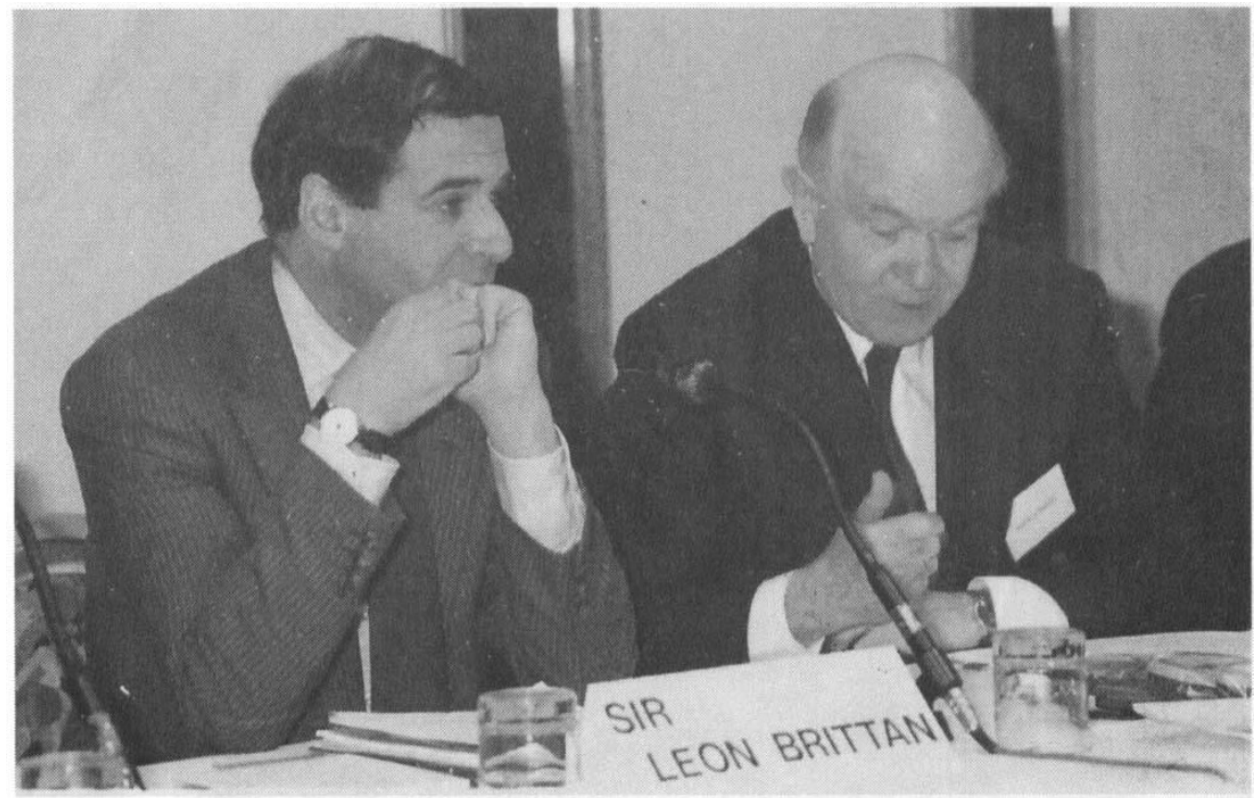

Sir Leon Brittan (Vice President, Commission of the European Communities, Brussels), Prof. Reimer Schmidt (President of the Geneva Association from 1986-1990). General Assembly of the Geneva Association, Brussels, 1990. 


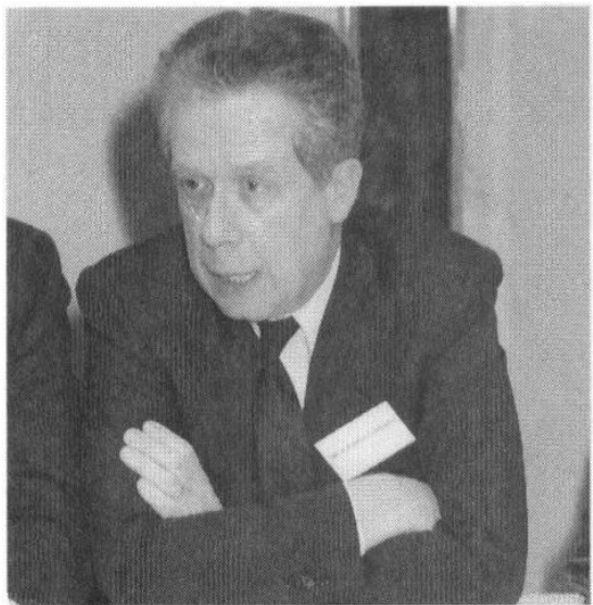

Tommaso Padoa-Schioppa

(Vice Director General, Bank of Italy, Rome). General Assembly of the Geneva Association, Brussels, 1990 .

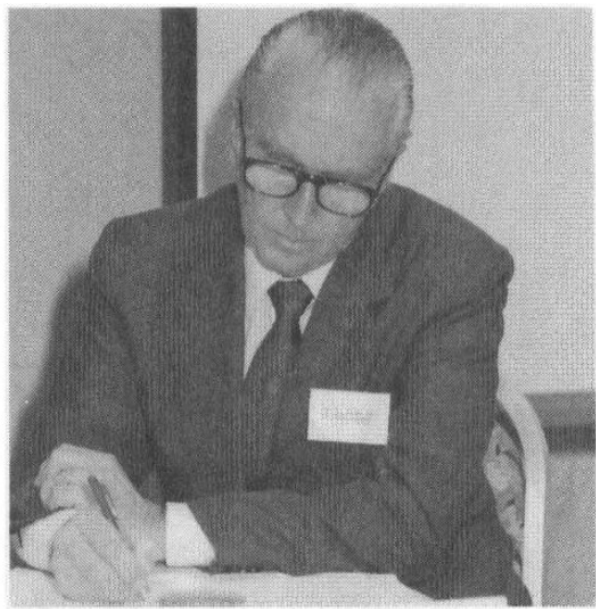

Rony Castro de Oliveira Lyrio

(President, Sul America Seguros, Rio de Janeiro). General Assembly of the Geneva Association, Brussels, 1990.

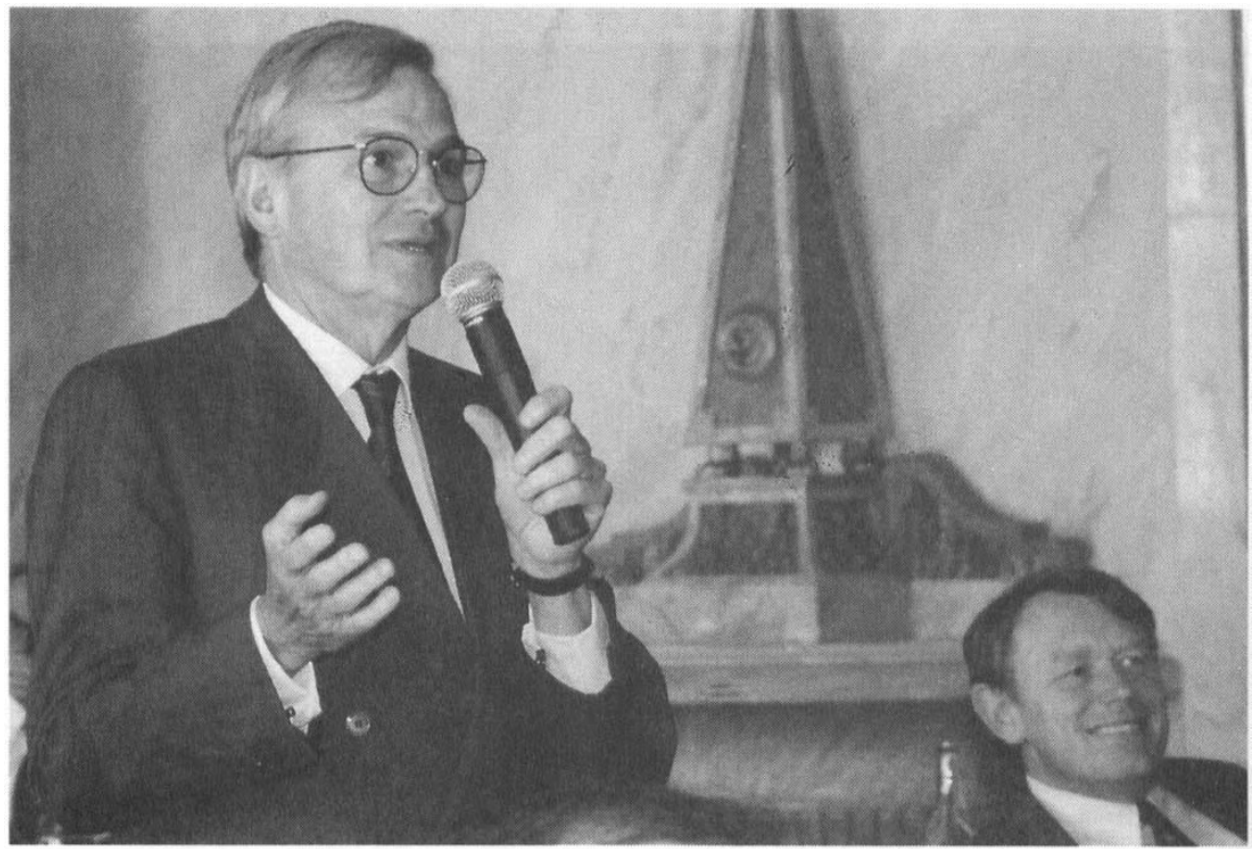

Claude Bebear (Chairman and CEO, AXA Group, Paris and Vice-President of the Geneva Association), Jan Holsboer (Member Executive Board, ING Group, Amsterdam and President of the Geneva Association). General Assembly of the Geneva Association, The Hague, 1988. 


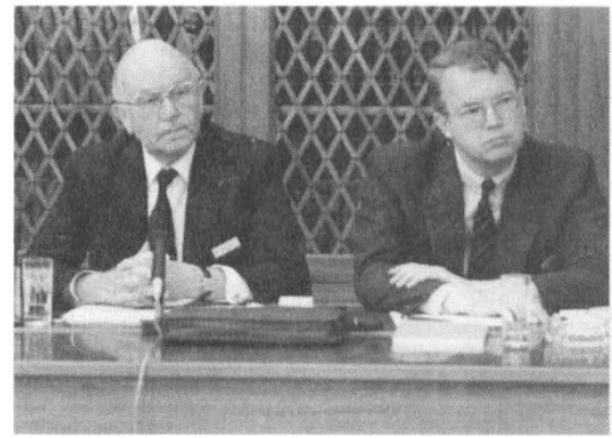

From the left: Prof. Reimer Schmidt (at the time, Managing Director, Achener Münchener),

Henning Schulte-Nöelle (now C.E.O., Allianz). General Assembly of the Geneva Association, Venice, 1983.

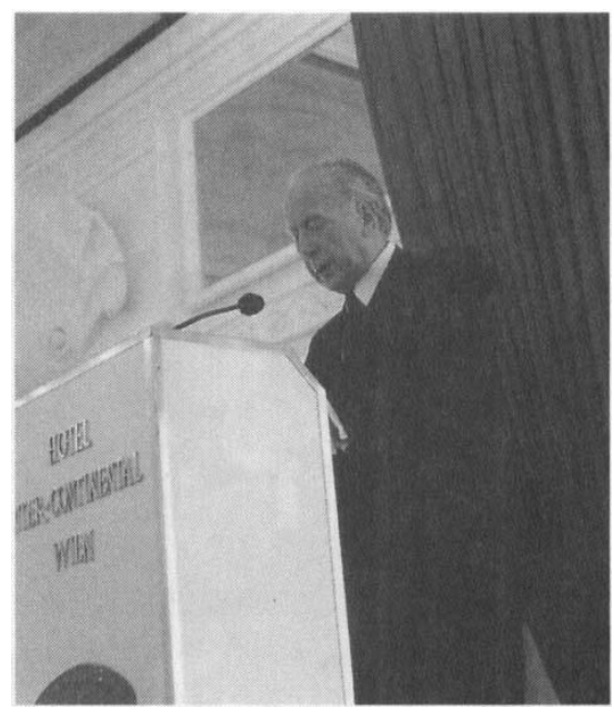

Cardinal Franz König, addressing the General Assembly of the Geneva Association in Vienna, 1993.

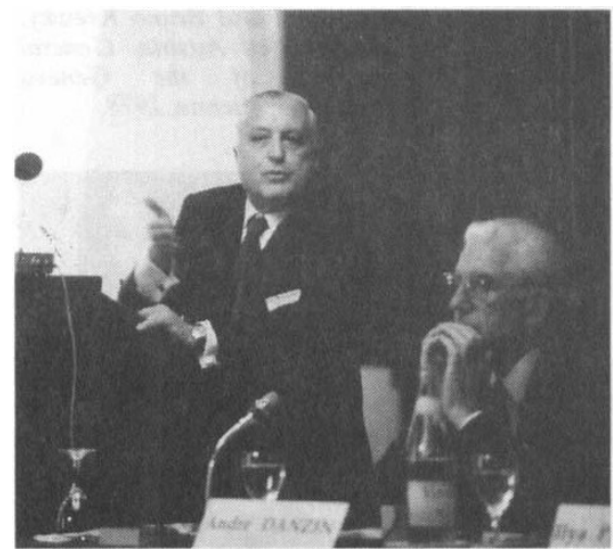

From the left: Professor Ilya Prigogine, Nobel Prize Winner, addressing the General Assembly of the Geneva Association on Uncertainty in Science and Society, André Danzin (Managing Director, Thomson).

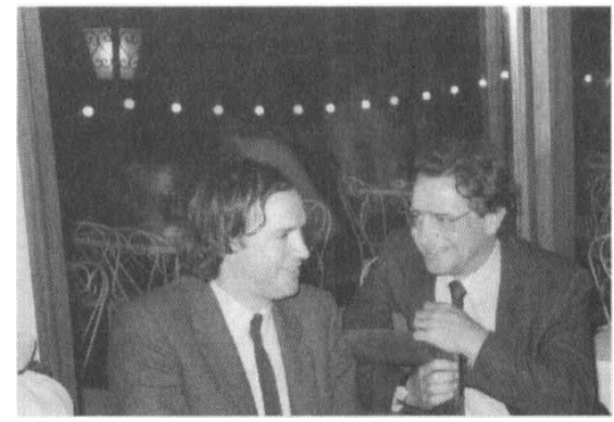

From the left: Denis Kessler (Currently General Manager, AXA), Orio Giarini (Secretary General, The Geneva Association). Eleventh Seminar of the European Group of Insurance Economists, Geneva, 1984. 


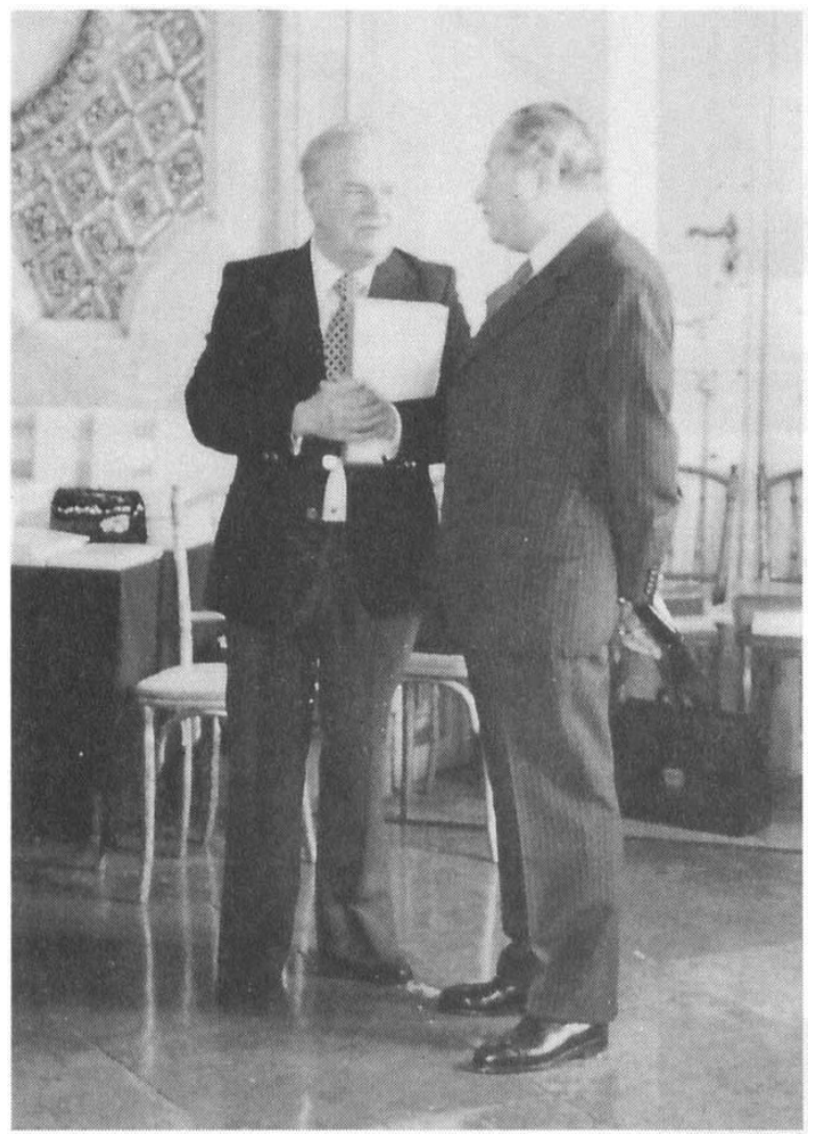

Nello Celio, former President of Switzerland and Bruno Kreisky, Chancellor of Austria. General Assembly of the Geneva Association, Vienna, 1978.

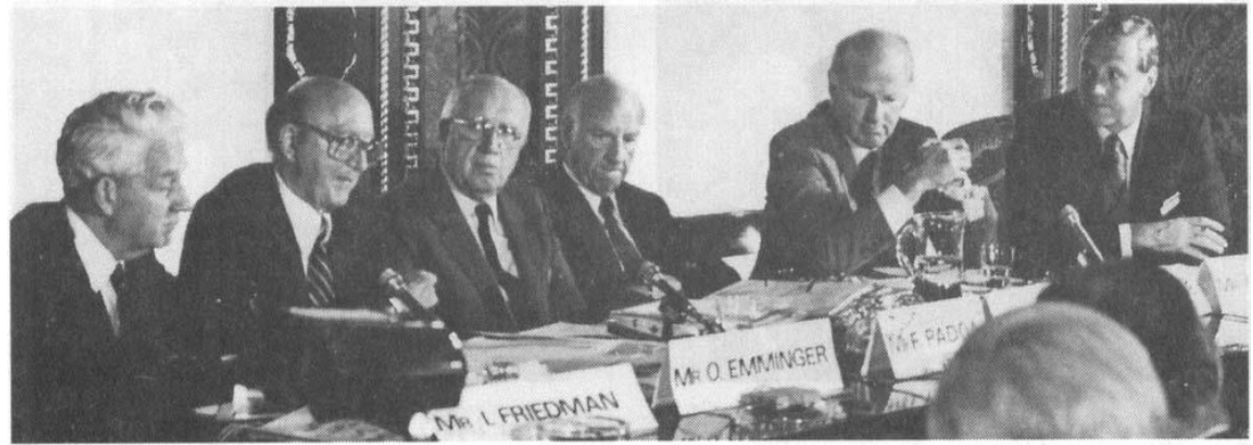

I. Friedman (Senior Advisor, First Boston Corporation), O. Emminger (former President of the Deutsche Bundesbank), F. Padoa, J. Neave, H. Rose (London School of Business Studies), N. Thygesen (University of Copenhagen). General Assembly, London, 1981. 


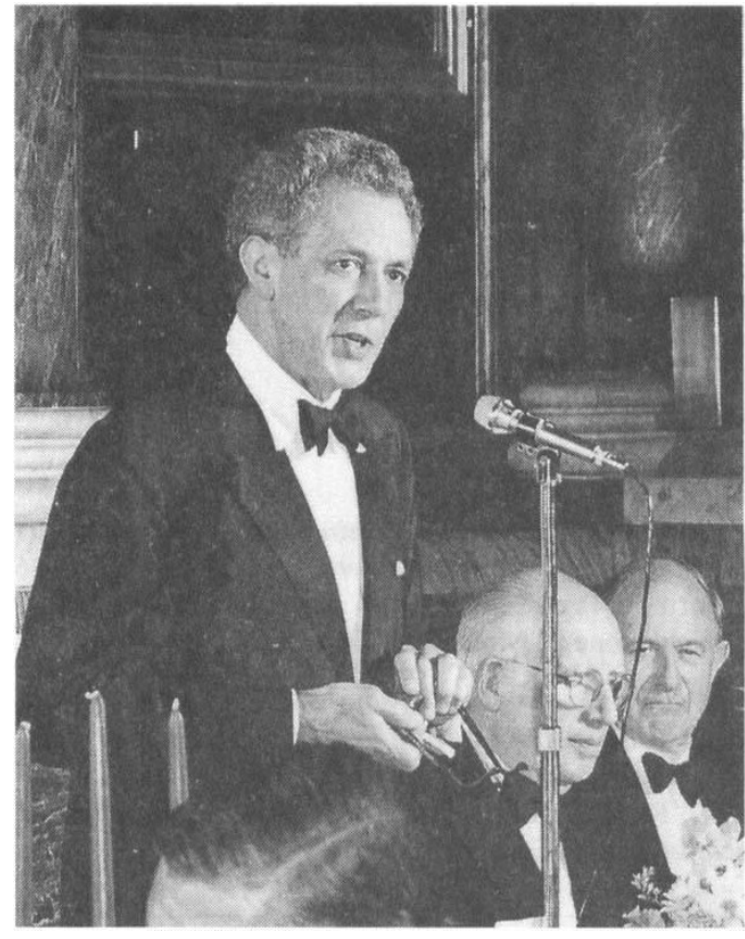

Sir Keith Joseph, Secretary of State for Industry, United Kingdom, addressing the General Assembly, London, 1981.

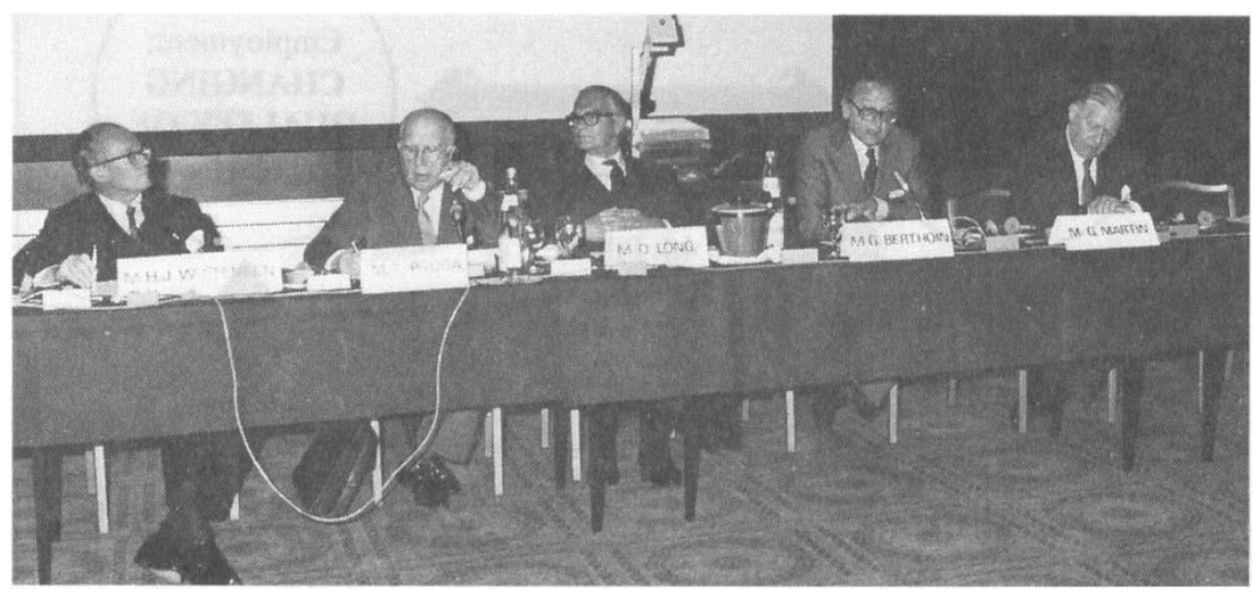

H. J. Witteveen (former Minister of Finance of Nederlands and Chairman of the Board of I.M.F.); F. Padoa; $O$. Long (Director General of GATT, Geneva); G. Berthoin (International President of the European Movement, European President of the Trilateral Commission, Paris); G. Martin; General Assembly, Geneva, 1980. 